Hydrology, Water Chemistry, and Revised Water Budgets for Tracy Segment Hydrographic Area, Storey, Washoe, and Lyon Counties, West-Central Nevada, 1998-2002

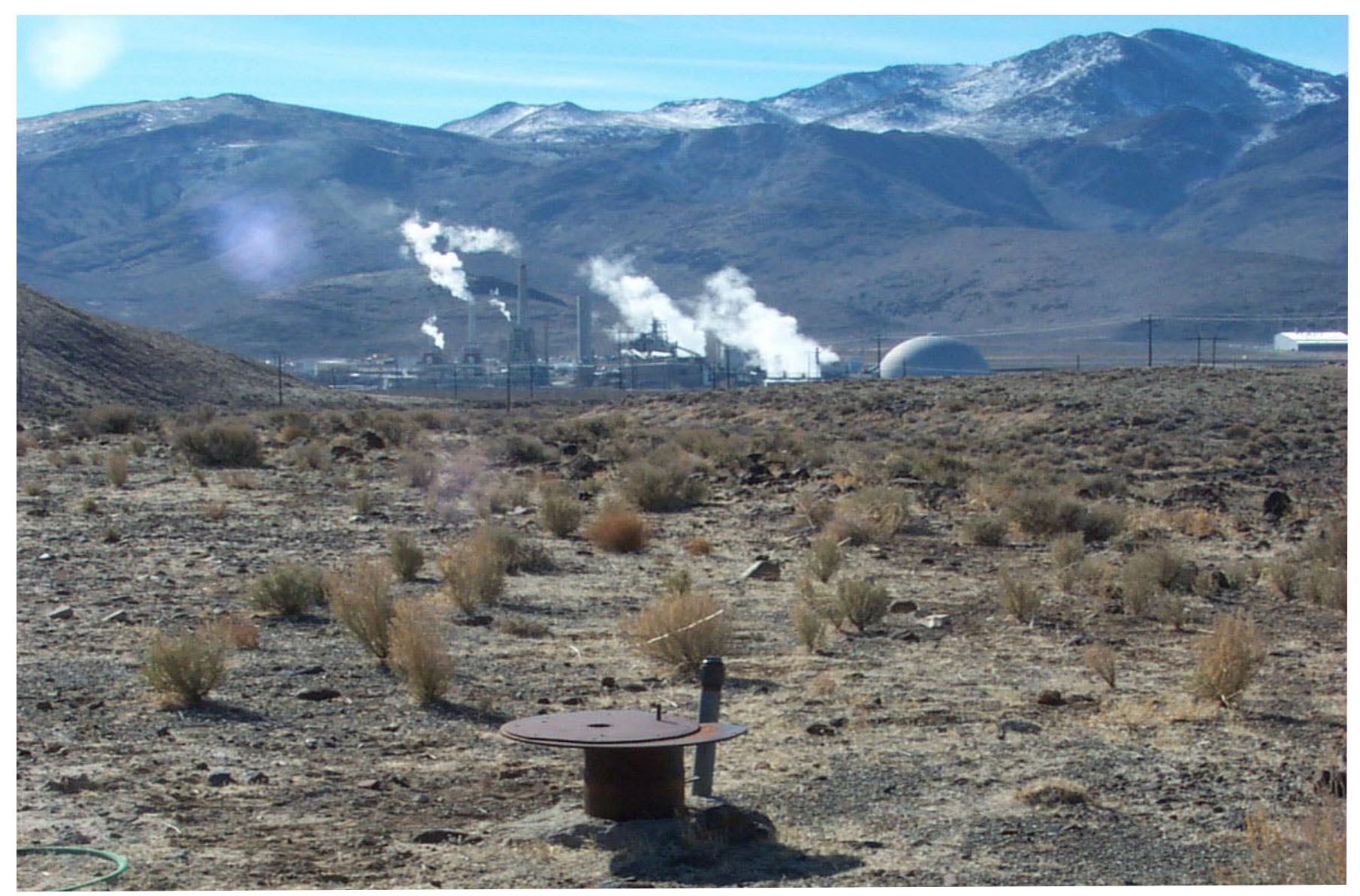

Prepared in Cooperation with

STOREY COUNTY

Scientific Investigations Report 2006-5010

U.S. Department of the Interior

U.S. Geological Survey 
COVER PHOTOGRAPH: View looking south at the Tracy Power Station on the south side of the Truckee River with the Virginia Range in the background. Photograph taken by Carl E. Thodal, April 2000. 


\section{Hydrology, Water Chemistry, and Revised Water Budgets for Tracy Segment Hydrographic Area, Storey, Washoe, and Lyon Counties, West-Central Nevada, 1998-2002}

By Carl E. Thodal and Mary L. Tumbusch

Scientific Investigations Report 2006-5010

Prepared in Cooperation with STOREY COUNTY

U.S. Department of the Interior

U.S. Geological Survey 


\section{U.S. Department of the Interior \\ Gale A. Norton, Secretary}

\section{U.S. Geological Survey \\ P. Patrick Leahy, Acting Director}

Use of trade, product, or firm names in this report is for identification purposes only and does not constitute endorsement by the U.S. Geological Survey.

Carson City, Nevada, 2006

For additional information write to:

U.S. Geological Survey

Director, USGS Nevada Water Science Center

2730 N. Deer Run Road

Carson City, NV 89701

Email: GS-W-NVpublic-info@usgs.gov

URL: http://nevada.usgs.gov/

For more information about the USGS and its products:

Telephone: 1-888-ASK-USGS

World Wide Web: http://www.usgs.gov/

Although this report is in the public domain, permission must be secured from the individual copyright owners to reproduce any copyrighted materials contained within this report.

Scientific Investigations Report 2006-5010 


\section{Contents}

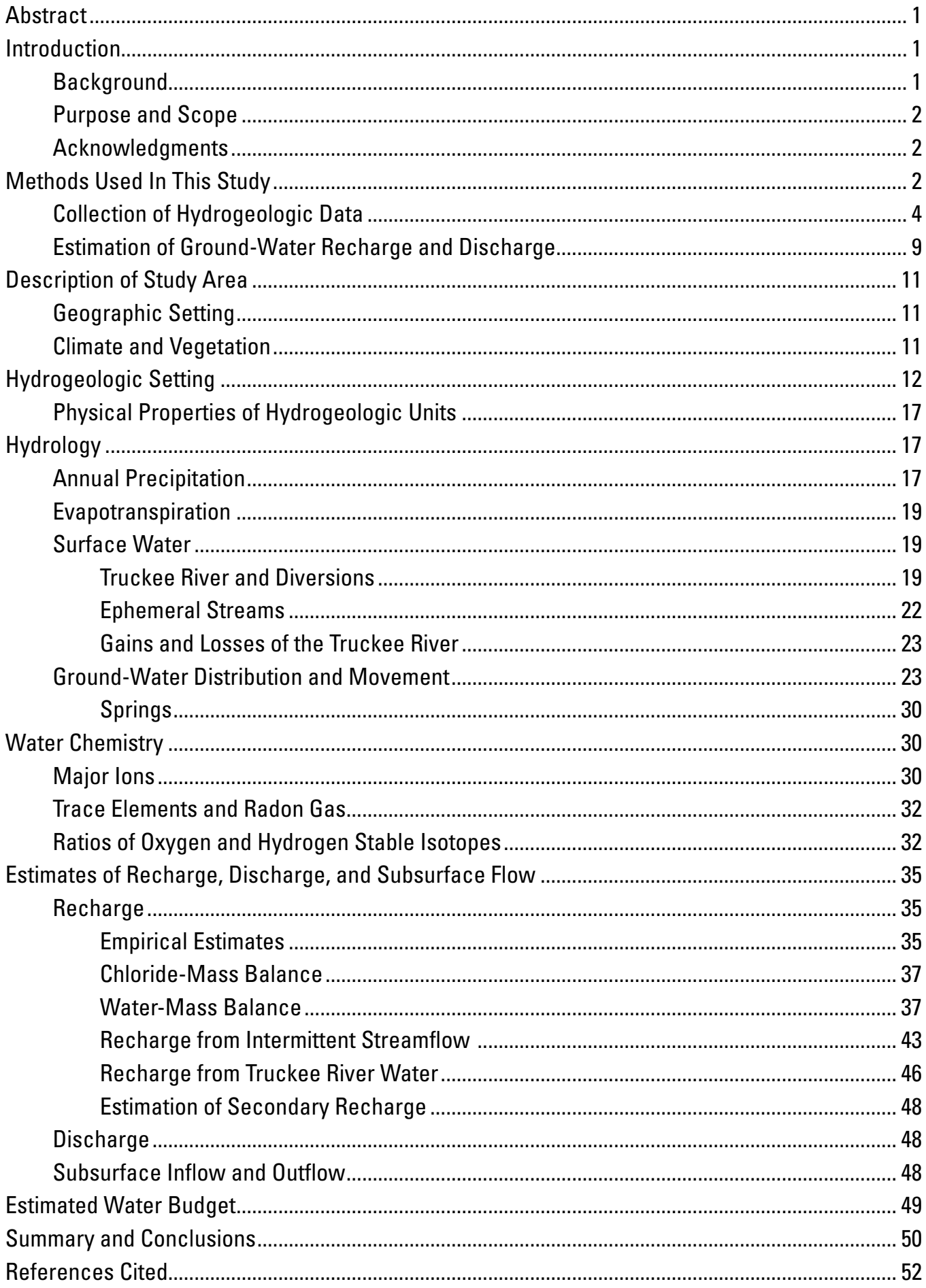




\section{Figures}

Figure 1. Location and selected geographic features of Tracy Segment HA and other hydrographic areas and locations of selected National Weather Service precipitation stations in west-central Nevada.

Figure 2. Locations of wells, precipitation sites, surface-water gage sites, micrometeorological sites, neutron-logging access-borehole/chloride-profile sites, and ephemeral streambed temperature-profiles sites, in and near the Tracy Segment Hydrographic Area, west-central Nevada.

Figure 3. Annual precipitation and cumulative departure from average annual precipitation measured at Virginia City and Reno, west-central Nevada, 1971-2002

Figure 4. Generalized distribution of dominant land cover, Tracy Segment Hydrographic Area, west-central Nevada.

Figure 5. Generalized geologic units and structural features of Tracy Segment Hydrographic Area, west-central Nevada

Figure 6. Average daily evapotranspiration measured at the desert shrub site at $5,200 \mathrm{ft}$ altitude, and at the pinion-juniper forest site at 6,100 ft altitude, January 2001October 2002, Tracy Segment Hydrographic Area, west-central Nevada

Figure 7. Average monthly evapotranspiration measured at the desert shrub site at $5,200 \mathrm{ft}$ altitude, and at the pinion-juniper forest site at 6,100 ft altitude, January 2001October 2002, Tracy Segment Hydrographic Area, west-central Nevada

Figure 8. Average water-level altitude for wells, 2000-2002, in and near the Tracy Segment Hydrographic Area, west-central Nevada.

Figure 9. Measured water-level fluctuations in selected wells completed in consolidatedrock aquifers in the mountain block, 2000-2002, Tracy Segment Hydrographic Area, west-central Nevada.

Figure 10. Measured water-level fluctuations in selected wells completed in consolidatedrock aquifers beneath alluvial-fan deposits, 2000-2002, Tracy Segment Hydrographic Area, west-central Nevada.

Figure 11. Relation between water-level fluctuations in nearby wells and Truckee River stage measured at U.S. Geological Survey streamflow-gaging station at Site 13 and near

Site 14, Tracy Segment Hydrographic Area, west-central Nevada.

Figure 12. Relation of deuterium to oxygen-18 for selected ground-water and Truckee River water samples, Tracy Segment Hydrographic Area, west-central Nevada

Figure 13. Chloride concentrations in pore water of unsaturated sediment, at selected sites in the Martin Canyon drainage basin, Tracy Segment Hydrographic Area, westcentral Nevada.

Figure 14. Changes in volumetric moisture content in unsaturated sediments at selected depths at selected sites in the Martin Canyon drainage basin, June 2001 through September 2002, Tracy Segment Hydrographic Area, west-central Nevada.

Figure 15. Relation of precipitation reported for National Weather Service station near Virginia City and maximum discharge recorded at crest-stage station on Long Valley Creek near Lockwood, Tracy Segment Hydrographic Area, west-central Nevada.

Figure 16. Hourly subsurface temperature recorded beneath intermittent stream channels in $\mathbf{A}$, Long Valley Canyon and B, Martin Canyon, Tracy Segment Hydrographic Area, and cumulative precipitation recorded at Virginia City, west-central Nevada. 


\section{Tables}

Table 1. Site number, location, and type of data available for precipitation, micrometeorological, soil-moisture and chloride-profile, thermocouple, surface-water, wells, and dry boreholes, Tracy Segment Hydrographic Area, west-central Nevada.

Table 2. Transmissivity of bedrock estimated by pumped-aquifer tests, Tracy Segment Hydrographic Area, west-central Nevada

Table 3. Precipitation data, normalized to 1971-2000, and selected estimates for stations in and near the Tracy Segment Hydrographic Area, west-central Nevada

Table 4. Estimated vegetation and land classification coverage, Tracy Segment Hydrographic Area, west-central Nevada

Table 5. Estimated mean annual precipitation, Tracy Segment Hydrographic Area, westcentral Nevada

Table 6. Average, maximum, minimum, and seasonal daily evapotranspiration rates, computed using the Bowen-ratio method, January 2001-September 2002, and annual total evapotranspiration for water year 2002, Tracy Segment Hydrographic Area, westcentral Nevada.....

Table 7. Information for surface-water gaging stations and diversions in and near Tracy Segment Hydrographic Area, west-central Nevada.

Table 8. Estimated area and mean annual runoff from ephemeral streams, Tracy Segment Hydrographic Area and selected subbasins (estimates are rounded), west-central Nevada

Table 9. Peak discharge at Long Valley Creek crest-stage gage (10350100) and precipitation recorded at National Weather Service station near Virginia City, Tracy Segment Hydrographic Area, west-central Nevada.

Table 10. Gain or loss of Truckee River streamflow in Tracy Segment Hydrographic Area, west-central Nevada, based on the difference between discharge measured by the U.S. Geological Survey at the Truckee River gaging station at Vista and the sum of discharge measured at the Truckee River gaging station at Vista and the sum of discharge measured at the Truckee River gaging station at Wadsworth and at the Truckee Canal near Wadsworth

Table 11. Summary of streamflow measurements and gains to and losses from Truckee River, Tracy Segment Hydrographic Area, west-central Nevada, 1971-1994.

Table 12. Nevada safe drinking-water standards

Table 13. Statistical summary of ground-water quality data, Tracy Segment Hydrographic Area, west-central Nevada, 2001-2003

Table 14. Statistical summary of surface-water quality data, U.S. Geological Survey Station Number 10350500, Truckee River at Clark, Tracy Segment Hydrographic Area, westcentral Nevada, 1991-2003.

Table 15. Percent composition of local recharge water and Truckee River water estimated from stable isotopic mixing for ground-water samples collected in the Tracy Segment Hydrographic Area, west-central Nevada.

Table 16. Estimated mean annual recharge from precipitation, Tracy Segment Hydrographic Area, west-central Nevada

Table 17. Chloride concentrations in pore-water extracts and selected physical characteristics of unsaturated-sediment samples collected from six test holes drilled in the Martin Canyon drainage basin, Tracy Segment Hydrographic Area, west-central Nevada. 
Table 18. Cumulative mass of chloride in pore water in unsaturated sediment samples, and chloride-age and average annual recharge rates estimated by chloride-mass balance, Tracy Segment Hydrographic Area, west-central Nevada

Table 19. Estimates of ground-water discharge, Tracy Segment Hydrographic Area, westcentral Nevada

Table 20. Estimates of water budget and of ground-water inflow and outflow for Tracy

Segment Hydrographic Area, west-central Nevada, 1998-2002 50 


\section{Conversion Factors}

\begin{tabular}{|c|c|c|}
\hline Multiply & By & To obtain \\
\hline \multicolumn{3}{|c|}{ Length } \\
\hline inch (in.) & 2.54 & centimeter $(\mathrm{cm})$ \\
\hline inch per day (in/d) & 2.54 & centimeter per day $(\mathrm{cm} / \mathrm{d})$ \\
\hline inch per year (in/yr) & 2.54 & centimeter per year $(\mathrm{cm} / \mathrm{yr})$ \\
\hline foot $(\mathrm{ft})$ & 0.3048 & meter $(\mathrm{m})$ \\
\hline mile (mi) & 1.609 & kilometer $(\mathrm{km})$ \\
\hline \multicolumn{3}{|c|}{ Area } \\
\hline acre & 4,047 & square meter $\left(\mathrm{m}^{2}\right)$ \\
\hline square foot $\left(\mathrm{ft}^{2}\right)$ & 929.0 & square centimeter $\left(\mathrm{cm}^{2}\right)$ \\
\hline square mile $\left(\mathrm{mi}^{2}\right)$ & 2.590 & square kilometer $\left(\mathrm{km}^{2}\right)$ \\
\hline \multicolumn{3}{|c|}{ Volume } \\
\hline gallon (gal) & 3.785 & liter $(\mathrm{L})$ \\
\hline cubic foot $\left(\mathrm{ft}^{3}\right)$ & 0.02832 & cubic meter $\left(\mathrm{m}^{3}\right)$ \\
\hline acre-foot (acre-ft) & 1,233 & cubic meter $\left(\mathrm{m}^{3}\right)$ \\
\hline \multicolumn{3}{|c|}{ Flow rate } \\
\hline acre-foot per year (acre-ft/yr) & 1,233 & cubic meter per year $\left(\mathrm{m}^{3} / \mathrm{yr}\right)$ \\
\hline acre-foot per year per mile (acre-ft/yr/mi) & 766 & cubic meter per year per kilometer $\left(\mathrm{m}^{3} / \mathrm{yr} / \mathrm{km}\right)$ \\
\hline foot per foot ( $\mathrm{ft} / \mathrm{ft})$ & 1 & meter per meter $(\mathrm{m} / \mathrm{m})$ \\
\hline foot per day (ft/d) & 0.3048 & meter per day $(\mathrm{m} / \mathrm{d})$ \\
\hline foot per year (ft/yr) & 0.3048 & meter per year $(\mathrm{m} / \mathrm{yr})$ \\
\hline cubic foot per second $\left(\mathrm{ft}^{3} / \mathrm{s}\right)$ & 0.02832 & cubic meter per second $\left(\mathrm{m}^{3} / \mathrm{s}\right)$ \\
\hline $\begin{array}{l}\text { cubic foot per second per square mile } \\
{\left[\left(\mathrm{ft}^{3} / \mathrm{s}\right) / \mathrm{mi}^{2}\right]}\end{array}$ & 0.01093 & $\begin{array}{l}\text { cubic meter per second per square kilometer } \\
{\left[\left(\mathrm{m}^{3} / \mathrm{s}\right) / \mathrm{km}^{2}\right]}\end{array}$ \\
\hline gallon per minute (gal/min) & 0.06309 & liter per second $(\mathrm{L} / \mathrm{s})$ \\
\hline gallon per day (gal/d) & 0.003785 & cubic meter per day $\left(\mathrm{m}^{3} / \mathrm{d}\right)$ \\
\hline inch per year (in/yr) & 25.4 & millimeter per year $(\mathrm{mm} / \mathrm{yr})$ \\
\hline \multicolumn{3}{|c|}{ Radioactivity } \\
\hline picocurie per liter $(\mathrm{pCi} / \mathrm{L})$ & 0.037 & becquerel per liter $(\mathrm{Bq} / \mathrm{L})$ \\
\hline \multicolumn{3}{|c|}{ Specific capacity } \\
\hline gallon per minute per foot $[(\mathrm{gal} / \mathrm{min}) / \mathrm{ft})]$ & 0.2070 & liter per second per meter $[(\mathrm{L} / \mathrm{s}) / \mathrm{m}]$ \\
\hline \multicolumn{3}{|c|}{ Hydraulic conductivity } \\
\hline foot per day (ft/d) & 0.3048 & meter per day $(\mathrm{m} / \mathrm{d})$ \\
\hline \multicolumn{3}{|c|}{ Hydraulic gradient } \\
\hline foot per mile $(\mathrm{ft} / \mathrm{mi})$ & 0.1894 & meter per kilometer $(\mathrm{m} / \mathrm{km})$ \\
\hline \multicolumn{3}{|c|}{ Transmissivity } \\
\hline foot squared per day $\left(\mathrm{ft}^{2} / \mathrm{d}\right)$ & 0.09290 & meter squared per day $\left(\mathrm{m}^{2} / \mathrm{d}\right)$ \\
\hline \multicolumn{3}{|c|}{ Leakance } \\
\hline foot per day per foot $[(\mathrm{ft} / \mathrm{d}) / \mathrm{ft}]$ & 1 & meter per day per meter $(\mathrm{m} / \mathrm{d} / \mathrm{m})$ \\
\hline \multicolumn{3}{|c|}{ Density } \\
\hline gram per cubic centimeter $\left(\mathrm{g} / \mathrm{cm}^{3}\right)$ & 62.4220 & pound per cubic foot $\left(\mathrm{lb} / \mathrm{ft}^{3}\right)$ \\
\hline
\end{tabular}


Temperature in degrees Celsius $\left({ }^{\circ} \mathrm{C}\right)$ may be converted to degrees Fahrenheit $\left({ }^{\circ} \mathrm{F}\right)$ as follows:

${ }^{\circ} \mathrm{F}=\left(1.8 x^{\circ} \mathrm{C}\right)+32$

Temperature in degrees Fahrenheit $\left({ }^{\circ} \mathrm{F}\right)$ may be converted to degrees Celsius $\left({ }^{\circ} \mathrm{C}\right)$ as follows:

${ }^{\circ} \mathrm{C}=\left({ }^{\circ} \mathrm{F}-32\right) / 1.8$

Vertical coordinate information is referenced to the insert datum name (and abbreviation) here for instance, "North American Vertical Datum of 1988 (NAVD 88)."

Horizontal coordinate information is referenced to the insert datum name (and abbreviation) here for instance, "North American Datum of 1983 (NAD 83)."

Altitude, as used in this report, refers to distance above the vertical datum.

Specific conductance is given in microsiemens per centimeter at 25 degrees Celsius $\left(\mu \mathrm{S} / \mathrm{cm}\right.$ at $\left.25^{\circ} \mathrm{C}\right)$.

Water-quality units used in this report

Microsiemens per centimeter $\quad \mu S / \mathrm{cm}$

Micrograms per liter $\quad \mu \mathrm{g} / \mathrm{L}$

Milligrams per liter $\quad \mathrm{mg} / \mathrm{L}$

Picocurie per liter $\quad \mathrm{pCi} / \mathrm{L}$ 


\title{
Hydrology, Water Chemistry, and Revised Water Budgets for Tracy Segment Hydrographic Area, Storey, Washoe, and Lyon Counties, West-Central Nevada, 1998-2002
}

\author{
By Carl E. Thodal and Mary L. Tumbusch
}

\section{Abstract}

Growth of the Reno/Sparks metropolitan area has resulted in development of rural and undeveloped land in the nearby Tracy Segment Hydrographic Area. A study of hydrology, inorganic water chemistry, distribution and movement of ground water, and water budgets for the 285 square mile hydrographic area began in 2000. Streamflow from the Truckee River and precipitation are dominant inflows of water to the Tracy Segment, and combined streamflow from the river and the Truckee Canal, along with evapotranspiration and consumptive water-use are the primary outflows. Estimated long term (1971-2000) mean-annual precipitation ranges in the study area from 150,000 to 200,000 acre-feet per year and during this study (water years 1998-2002) the range was adjusted from 130,000 to 174,000 acre-feet per year. Water year used herein is the 12-month period October 1 through September 30 . The water year is designated by the calendar year in which the 12-month period ends. Data from two micrometeorological stations located at 5,000 and 6,000 feet above sea level indicated that evapotranspiration of surface and soil moisture consumed 124,000 to 158,000 acre-feet per year during water year 2002. An additional 6,000 acre-feet per year is estimated to be transpired from ground water by phreatophytes.

Average flow of the Truckee River (water years 19982002) was 614,000 acre-feet per year at the upstream Tracy Segment Hydrographic Area boundary and 616,000 acrefeet per year near the downstream boundary crossed by the Truckee River and Truckee Canal. Five active agricultural diversions and one industrial diversion total an average flow of 9,000 acre-feet per year. About 5,000 acre-feet per year of flow may discharge to the river from tributary ephemeral channels. Streamflow data indicate a net gain of 11,000 acrefeet per year from ground water. Seepage loss to ground water beneath the Truckee Canal was estimated to be about 9,000 acre-feet per year, much of which contributed to gains in the lower reach of the river.

Depth to water at 30 wells ranged from about 25 feet above land surface at a flowing well completed in permeable bedrock to more than 400 feet below land surface in a test well completed in bedrock beneath an alluvial fan. Water levels measured in wells completed in basin-fill deposits near the Truckee River are less than 30 feet below land surface and indicate a hydraulic gradient that parallels the river. Subsurface inflow from the Fernley Hydrographic Area was estimated at 3,200 acre-feet per year, most of which was from diverted irrigation water. Ground-water pumpage (2000) was 8,200 acre-feet per year and subsurface outflow to Dodge Flat Hydrographic Area was estimated at 2,400 acre-feet per year.

Ground-water samples collected from 11 wells indicated that ground water generally is suitable for drinking water and industrial supplies with a few exceptions. Concentrations of dissolved arsenic exceeded the current maximum contaminant level (50 micrograms per liter) at two sites and the future maximum contaminant level (10 micrograms per liter) was exceeded at four additional sites. The proposed maximum contaminant level for dissolved radon gas (300 picocuries per liter) was exceeded in 10 of the 11 samples collected. Secondary maximum contaminant levels for dissolved fluoride, manganese, iron, and dissolved solids were exceeded at three, two, one, and two wells, respectively. Stable isotopes of hydrogen and oxygen in samples indicate that 8 ground-water samples are mixtures of 11-94 percent Truckee River water and ground water represented by samples from 3 wells completed in the mountain blocks.

Water-budget estimates for water years 1998 through 2002 indicate total inflow ranged from 748,000 to 791,000 acre-feet per year and outflow ranged from 759,000 to 793,000 acre-feet per year. Ground-water inflow ranged from 78,000 to 101,000 acre-feet per year and outflow was 88,000 acre-feet per year. Surface water of the Truckee River dominates both total- and ground-water budget estimates, comprising about 80 percent of total inflow and outflow, and about 61 and 81 percent of ground-water inflow and outflow, respectively. Ground-water pumpage is about 9 percent of groundwater discharge.

\section{Introduction}

\section{Background}

Rapid growth of the Reno/Sparks metropolitan area in western Nevada has resulted in development of nearby rural and undeveloped land. These two cities grew 32 percent from 
Hydrology, Water Chemistry, and Revised Water Budgets for Tracy Segment Hydrographic Area, 1998-2002

1980 through 1990 and had a combined population of about 187,000 in 1990 (Jones and others, 1991). The 2000 Census indicated that the combined population for these two cities has continued to increase to more than 240,000 (U.S. Census Bureau, Census 2000). The proximity of the Tracy Segment Hydrographic Area (HA), ${ }^{1}$ herein referred to as the Tracy Segment (fig. 1), to the Reno/Sparks area has resulted in changes in its land use and related water-supply requirements.

When considering the approval or denial of a water rights application for ground water, Nevada water law requires the State Engineer to determine if water is available in the HA and whether granting of the water right would prove detrimental to the public interest or would impair existing water rights. Estimates of long-term average annual ground-water budgets (an accounting of recharge and discharge) have been used as a guide for addressing availability of water within an HA. Inflows to ground water in the Tracy Segment may include (1) infiltration of precipitation and streamflow generated within the area; (2) infiltration of streamflow from the Truckee River; (3) infiltration of water used for municipal, industrial, domestic, and agricultural purposes; and (4) subsurface inflow from adjacent HAs. Outflows from ground water may include (1) losses to the atmosphere by evapotranspiration (ET); (2) ground-water seepage to the Truckee River and to springs; (3) ground-water pumping and subsequent consumptive uses; and (4) subsurface outflow to adjacent HAs.

The water budget for the Tracy Segment was last assessed in the early 1970's as part of a brief water-resources appraisal of the Truckee River Basin (VanDenburgh and others, 1973). On the basis of that report, the Nevada State Engineer designated the perennial yield of basin-fill aquifers in the Tracy Segment at 6,000 acre-ft/yr. Perennial yield is defined as "The amount of usable water from a ground-water aquifer that can be economically withdrawn and consumed each year for an indefinite period of time. It cannot exceed the natural recharge to that aquifer and ultimately is limited to the maximum amount of discharge that can be utilized for beneficial use" (Nevada Division of Water Planning, 1992, p. 73). Since then, numerous water-supply and exploratory wells have been constructed to intercept ground water in volcanic-rock aquifers which the reconnaissance study assumed to be impermeable or otherwise insignificant. Although ground water has been found in volcanic-rock aquifers, the source of its recharge is limited to precipitation falling within the Tracy Segment plus water that infiltrates from the Truckee River and ground water that enters the area from adjacent HAs. In 2000, the U.S. Geological Survey (USGS), in cooperation with Storey County, began a study of water resources in the Tracy Segment to provide information necessary to plan for development within the area and for efficient management of the water resources.

\section{Purpose and Scope}

This report describes the results of a water-resources study designed to evaluate and refine estimates of the water budget and the sustainable long-term perennial yield of aquifer systems in the Tracy Segment and to characterize the quality of ground water in terms of drinking-water standards for dissolved inorganic constituents. The Department of Conservation and Natural Resources, Nevada Division of Water Resources delineated the Tracy Segment in terms of geography, climate and vegetation, geology, and hydrology, and includes a revised ground-water budget.

The scope of this investigation included compilation and evaluation of available data for precipitation, streamflow, vegetation, geology, and ground water. Data also were collected for precipitation, soil moisture, ephemeral streamflow, and ground-water levels. Surface- and ground-water samples were collected for chemical analysis. Data were evaluated in terms of hydrologic and ground-water budgets and drinking-water quality of the Tracy Segment.

\section{Acknowledgments}

This report documents a study made in cooperation with Storey County Building and Planning Department. The authors thank private land owners who allowed access to their wells for water-level measurements and water-sample collection. Dale Bugenig of Eco-Logic Engineering; Brad Hart of Brown and Caldwell; Dennis McCormick of Kal Kan Pet Care; Gary Shaw and Brian Lawson of Sierra Pacific Power Company; and Steve McKay of McKay Drilling, Inc., all provided valuable data and information on pumped-aquifer tests, water levels, well construction, and water use. Tom Swan and Helene Decker of Truckee Meadows Water Reclamation Facility provided access for test drilling and the location of monitoring wells. David Wathen of the Federal Water Master's office provided information on irrigation diversions and Gary Barbato of the National Oceanic and Atmospheric Administration provided data for weather stations.

\section{Methods Used In This Study}

Several methods were used to analyze ground-water flow systems of the Tracy Segment and to determine components of the hydrologic budget for the study area. These methods required data collection from precipitation and micrometeorological stations, subsurface instrumentation that monitored profiles of moisture and temperature, samples of subsurface sediments to determine chloride concentrations, continuous and intermittent measurements of perennial and ephemeral streamflow and ground-water elevations, ground-water level responses to pumped-well aquifer tests, and from chemi-

\footnotetext{
${ }^{1}$ Formal hydrographic areas in Nevada were delineated systematically by the U.S. Geological Survey and Nevada Division of Water Resources in the late 1960's for scientific and administrative purposes (Rush, 1968; Cardinalli and others, 1968). The official hydrographic-area names, numbers, and geographic boundaries continue to be used in USGS scientific reports and Division of Water Resources administrative activities.
} 


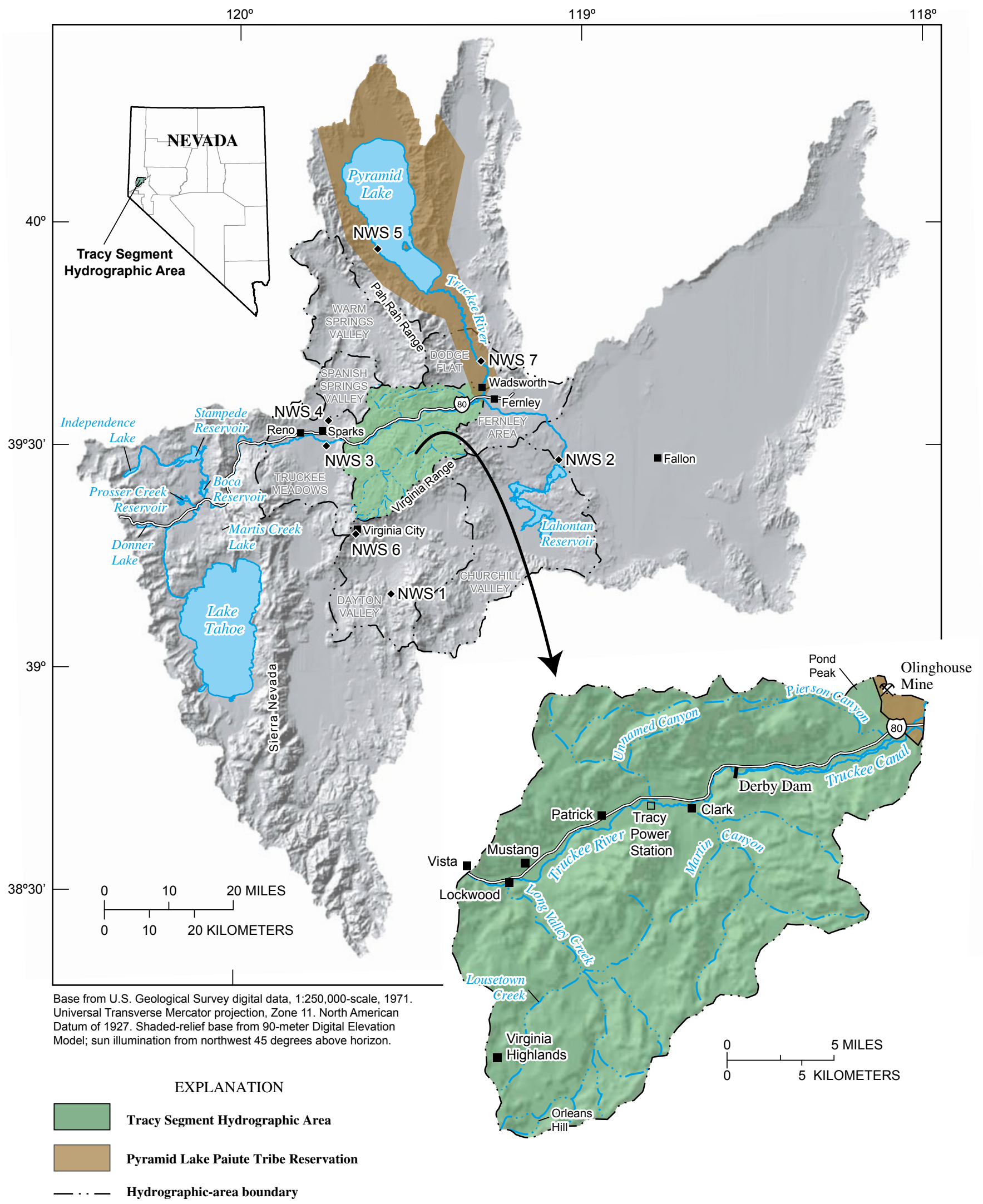

NWS 7. National Weather Service precipitation stationSee table 2 for station identifier

Figure 1. Location and selected geographic features of Tracy Segment HA and other hydrographic areas and locations of selected National Weather Service precipitation stations in west-central Nevada 
Hydrology, Water Chemistry, and Revised Water Budgets for Tracy Segment Hydrographic Area, 1998-2002

cal analyses of samples of surface water and ground water. Chemical analyses also were used to evaluate how suitable water resources are for domestic and industrial uses. General descriptions of the types of data used, collection procedures, and data applications are described in the following sections.

\section{Collection of Hydrogeologic Data}

Information about the sites used to monitor hydrology within the Tracy Segment is listed in table 1, site numbers and locations are shown in figure 2. Ground-water levels and water-chemistry data are published by the USGS in the Water Resources Data for Nevada, Water Year 2003 report (Stockton and others, 2004, p. 605-613) and real-time and historical data for selected streamflow-gaging stations on the Truckee River are available online at http://waterdata.usgs.gov/nv/nwis/nwis.

Precipitation was measured quarterly or as necessary at four National Weather Service rain and snow bulk-storage collectors (sites 1-4, table 1). Each collector contained a mixture of light mineral oil and ethylene glycol to prevent evaporation and freezing and all were located at altitudes higher than 5,000 ft.

Selected micrometeorological data were collected at two precipitation sites (sites 3 and 4) to estimate the amount of moisture which was returned from recharge areas to the atmosphere by non-phreatophytic ET. Site 3 was at an elevation of about 5,200 ft in a desert shrub plant community of low sagebrush, perennial grasses, and bare soil and is representative of about 66 percent of the Tracy Segment. Site 4 was at an elevation of about $6,000 \mathrm{ft}$ in a pinion-juniper forest with a sparse understory of low shrubs and perennial grasses and is representative of about 17 percent of the Tracy Segment. Both ET sites were located such that abrupt changes in surface conditions were at least $500 \mathrm{ft}$ from the instrumentation in order for the air-flow profile to be approximately laminar.

Instrumentation at each micrometeorological site consisted of (1) two solid-state temperature and relative-humidity probes mounted on an exchange mechanism designed to remove sensor bias; (2) an anemometer to measure wind speed; (3) a set of heat-flux plates, thermocouples, and a water-content reflectometer buried beneath the site to compute the subsurface-heat flux; and (4) a National Weather Servicestyle standard rain and snow gage. Energy fluxes and ET were computed every 20 minutes based on 10 or 30 second measurement intervals. Daily values of ET were computed by summation. Missing or questionable data that resulted from equipment malfunction or data invalidation were replaced with a running average of measurements recorded prior to and subsequent to the missing data.

Six boreholes were drilled in the Martin Canyon drainage basin (sites 5-10; fig. 2) to depths of about $26 \mathrm{ft}$ below land surface using an ODEX air hammer drilling method. Drill-site altitudes ranged from 4,400 to 5,200 ft and five of these sites were drilled in ephemeral stream channels. Twenty core samples collected from five of the six boreholes were used to determine bulk density and water content in the USGS laboratory in Carson City, Nevada using a gravimetric method (Gardner, 1965, p. 92-96). Thin-walled aluminum casing was installed in each borehole and the annulus backfilled with polyurethane foam (Zawislanski and Faybishenko, 1999) to provide access for a neutron-moisture meter probe. The meter was calibrated by linear regression using repeated meter readings on June 13 and 14, 2001, at borehole depths corresponding with locations of 20 core samples collected for laboratory determination of volumetric moisture content.

Temperature-profile time-series data have been used as a marker of intermittent streamflow and to estimate rates of vertical infiltration and streambed permeability (Lapham, 1989). Arrays of thermocouples (type T, copper constantan wire) were installed in ephemeral channels to depths of about 6.2 and $3.6 \mathrm{ft}$ in Martin Canyon (site 11; sensors at 0, 0.3, 1.0, 1.6, 3.3, and $6.2 \mathrm{ft}$ ) and Long Valley Canyon Creek (site 12; sensors at $0,0.3,1.0,1.6,2.3$, and $3.6 \mathrm{ft}$ ), respectively (fig. 2) and wired to data loggers programmed to read the temperature every 30 seconds and record hourly averages. Site 11 operated from September 28, 2001, through December 12, 2002, and site 12 operated from October 5, 2001, through November 27, 2002.

Within or near the Tracy Segment, the USGS operates four streamflow-gaging stations on the Truckee River (sites 13, 14, 15, and 17; fig. 2) and one site on the Truckee Canal (site 16; fig. 2). Stage-recording devices were used to compute discharge on the basis of stage, channel geometry, and instantaneous streamflow measurements made using a standard USGS wading rod and flow meter. Long-term records of streamflow have been collected near the upstream (site 13, Truckee River at Vista, USGS station number 10350000) and downstream (site 17, Truckee River at Wadsworth, 10351650; and site 16, Truckee Canal near Wadsworth, 10351300) boundaries of the Tracy Segment. Site 13 has operated continuously since October 1958 with intermittent operation since August 1899. Site 17 began operating in May 1965, but was discontinued for the 7-yr period from September 1986 until it was re-established in September 1993. Site 16 has been operating since October 1966 (Berris and others, 2003, p. 386, 395 and 400). There also are five active diversions from the Truckee River to irrigation canals and three for industrial use (Federal Water Master, written commun., 2003).

Measurements of instantaneous discharge have been made at various locations within the Tracy Segment as part of seepage studies to determine ground water exchange along the Truckee River. The first recorded seepage measurements in the Tracy Segment were made in September 1971, downstream of Derby Dam (U.S. Geological Survey, 1972, p. 174) and subsequent seepage measurements were made in October 1991 and September 1992 (Hess and others, 1993, p. 400-402), November 1993 (Clary and others, 1995, p 557), and January and November 1994 (Bauer and others, 1996, p. 535). Seepage measurements are made during low flow because uncertainties associated with streamflow measurements (about 5 percent) are small relative to differences between low-flow measurements. 


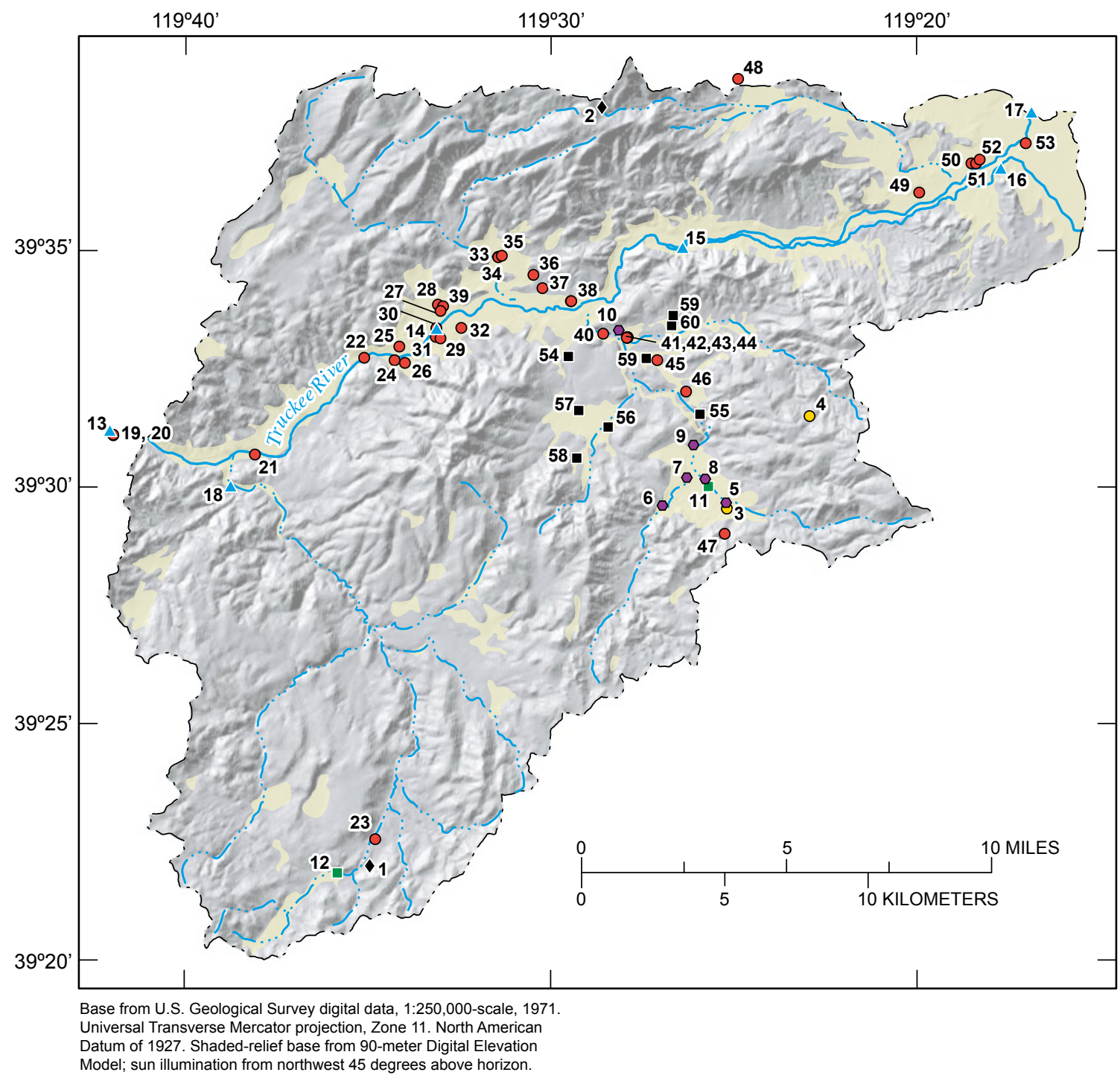

\section{EXPLANATION}

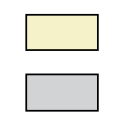

Basin-fill deposits

Consolidated rock

Hydrographic-area boundary
Sites used in this study—-Solid symbol indicates water chemistry. Number corresponds to table 1

\footnotetext{
1 - Precipitation site

3 ○ Micrometeorological site

5 Soil moisture and chlorideprofile site
}

$$
\begin{aligned}
& \text { 11. Thermocouple site } \\
& 13 \text { A Streamflow gaging site } \\
& \text { 21。 Well site- } \\
& \text { Measured on well run }
\end{aligned}
$$

Figure 2. Locations of wells, precipitation sites, surface-water gage sites, micrometeorological sites, neutron-logging access-borehole/chloride-profile sites, and ephemeral streambed temperature-profiles sites, in and near the Tracy Segment Hydrographic Area, west-central Nevada. 
Table 1. Site number, location, and type of data available for precipitation, micrometeorological, soil-moisture and chloride-profile, thermocouple, surface-water, wells, and dry boreholes, Tracy Segment Hydrographic Area, west-central Nevada

[Standard identification: Based on the grid system of latitude and longitude and consists of 15 digits. The first 6 digits denote the degrees, minutes, and seconds of latitude; the next seven digits denote the degrees, minutes, and seconds of longitude; and the last two digits are assigned sequentially identify the sites within a one-second grid. Local identification: Based on an index of hydrographic areas in Nevada (Rush, 1968) and on the rectangular subdivision of the public lands referenced to the Mount Diablo base line and meridian. Each number consists of four units. The first unit is the hydrographic area number. The second unit is the township, preceded by $\mathrm{N}$ to indicate location north of the base line. The third unit is the range, preceded by $\mathrm{E}$ to indicate location east of the meridian. The fourth unit consists of the section number and letters designating the quarter section, quarter-quarter section, and so on (A, B, C, and D indicate the northeast, northwest, southwest, and southeast quarters, respectively), followed by a number indicating the sequence in which the site was recorded. Available data: P, precipitation; ET, evapotranspiration; SM, soil moisture; CL, chloride concentrations in pore-water extracts; ST, subsurface temperature; Q, discharge; QW, water chemistry; D, dry borehole location; WL, ground-water levels; T, transmissivity estimated by aquifer-test analysis]

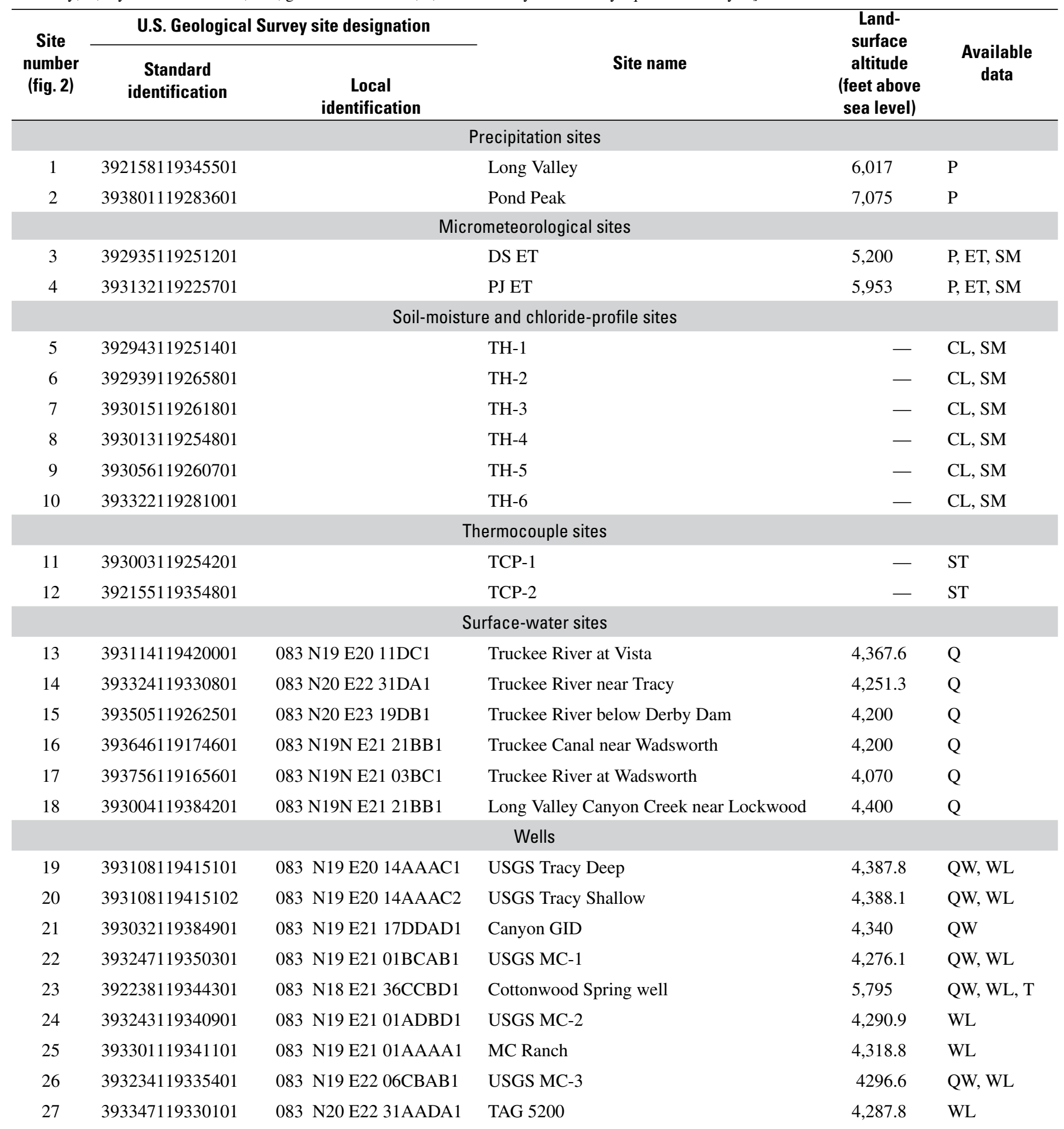


Table 1. Site number, location, and type of data available for precipitation, micrometeorological, soil-moisture and chloride-profile, thermocouple, surface-water, wells, and dry boreholes, Tracy Segment Hydrographic Area, west-central Nevada—Continued

\begin{tabular}{|c|c|c|c|c|c|}
\hline \multirow{2}{*}{$\begin{array}{c}\text { Site } \\
\text { number } \\
\text { (fig. 2) }\end{array}$} & \multicolumn{2}{|c|}{ U.S. Geological Survey site designation } & \multirow[b]{2}{*}{ Site name } & \multirow{2}{*}{$\begin{array}{c}\text { Land- } \\
\text { surface } \\
\text { altitude } \\
\text { (feet above } \\
\text { sea level) }\end{array}$} & \multirow{2}{*}{$\begin{array}{c}\text { Available } \\
\text { data }\end{array}$} \\
\hline & $\begin{array}{c}\text { Standard } \\
\text { identification }\end{array}$ & $\begin{array}{l}\text { Local } \\
\text { identification }\end{array}$ & & & \\
\hline \multicolumn{6}{|c|}{ Wells-Continued } \\
\hline 28 & 393424119314401 & 083 N20 E22 28BCCB1 & Corral & $4,354.9$ & WL \\
\hline 30 & 393324119330401 & 083 N20 E22 31DAAC1 & KK & $4,270.8$ & QW, WL \\
\hline 31 & 393312119331201 & 083 N20 E22 31DDBA1 & PAT deep & $4,309.8$ & QW, WL \\
\hline 32 & 393323119322401 & 083 N20 E22 32CAA1 & WS-1 & 4,310 & $\mathrm{~T}$ \\
\hline 33 & 393447119312301 & 083 N20 E22 21CDCD1 & DLC\#3 & $4,456.8$ & WL \\
\hline 34 & 393447119312302 & 083 N20 E22 21CDCD2 & DLC\#2 & $4,455.2$ & WL \\
\hline 37 & 393414119301401 & 083 N20 E22 27CAAC1 & Equipment & $4,273.0$ & WL \\
\hline 38 & 393358119292801 & 083 N20 E22 26CCCA1 & Irrigation & 4,250 & WL \\
\hline 39 & 393352119325801 & 083 N20 E22 32BBAB1 & Stock\#5 & $4,298.7$ & WL \\
\hline 40 & 393316119283901 & 083 N20 E22 35DACD1 & TRIMW4 & 4,380 & QW, WL \\
\hline 41 & 393313119275503 & 083 N20 E22 36CDAB2 & $\mathrm{W}-36 \mathrm{~N}$ & 4,460 & WL \\
\hline 42 & 393313119275501 & 083 N20 E22 36CDAB1 & $\mathrm{W}-36$ & $4,438.9$ & WL, T \\
\hline 43 & 393312119275501 & 083 N20 E22 36CDAB4 & $\mathrm{W}-36 \mathrm{~S}$ & 4,446 & WL \\
\hline 44 & 393312119275601 & 083 N20 E22 36CDAB5 & W-36W & 4,429 & WL \\
\hline 45 & 393244119270701 & 083 N19 E22 01AADD1 & Coyote & $4,545.4$ & WL \\
\hline 51 & 393652119182701 & 083 N20 E24 08DBAB1 & CantlonM & $4,091.9$ & WL \\
\hline 52 & 393657119182101 & 083 N20 E24 08ADCC1 & CantlonE & $4,108.5$ & WL \\
\hline \multirow[t]{2}{*}{53} & 393718119170201 & 083 N20 E24 09AAAA1 & BigBend\#3 & 4,085 & QW, WL \\
\hline & & & Dry borehole & & \\
\hline 54 & 393248119293101 & 083 N19 E22 03AA1 & $\mathrm{W}-3$ & 4,460 & $\mathrm{D}$ \\
\hline 55 & 393135119255601 & 083 N19 E23 08BB1 & $\mathrm{W}-8$ & 4,760 & $\mathrm{D}$ \\
\hline 56 & 393119119282601 & 083 N19 E22 11DD1 & $\mathrm{W}-13$ & 4,720 & $\mathrm{D}$ \\
\hline 57 & 393140119291501 & 083 N19 E22 11BC1 & $\mathrm{W}-10$ & 4,630 & $\mathrm{D}$ \\
\hline 58 & 393039119291801 & 083 N19 R22 14DC1 & WH & 4,980 & $\mathrm{D}$ \\
\hline 59 & 393327119264201 & 083 N20 R23 31BD1 & $\mathrm{WH} 2$ & 4,720 & $\mathrm{D}$ \\
\hline 60 & 393340119264001 & 083 N20 R23 31BA1 & WH3 & 4,720 & $\mathrm{D}$ \\
\hline 61 & 393246119272401 & 083 N19 R22 01AC1 & WH4 & 4,530 & $\mathrm{D}$ \\
\hline
\end{tabular}


Depth-to-water measurements were made at 33 of the 35 well sites listed in table 1 from July 2000 through March 2003 , using a steel tape, an electric tape, or calibrated recording pressure transducer. These data were used to determine ground-water flow directions, evaluate seasonal variability, and ground-water response to changes in the Truckee River streamflow and pumped-well aquifer tests. Depth-to-water measurements and other information regarding wells visited during this study are listed in appendix 2 .

Estimates of the transmissivity of bedrock hydrogeologic units were made from four aquifer tests (table 2) using wells completed in fractured bedrock aquifers and analyzed using computer spreadsheets that incorporate analytical solution(s) of the partial differential equation for ground-water flow to a well (Halford and Kuniansky, 2002). The first test (Consulting Services Associates, Inc, 1997) was a single well, 5.9-hr step drawdown and recovery test made on March 13, 1996, to evaluate aquifer properties using a test well (site 32) constructed with a screened interval in both basin-fill and fractured volcanic rocks. The well discharged $100 \mathrm{gpm}$ for the first 70 minutes, $200 \mathrm{gpm}$ for the next 25 minutes, and $310 \mathrm{gpm}$ for 260 minutes. Two multiple-well continuous-stress pump tests were made on April 25-28, 2001, (site 42) and on April 5-7, 2002, (site 29). Site 42 discharged ground water for 72 hours from an unconfined, fractured bedrock aquifer at a rate of $375 \mathrm{gpm}$ and water levels were monitored in five observation wells that ranged from 43 to $4,800 \mathrm{ft}$ away. Site 29 was pumped at an average rate of 510 gpm for 72 hours from a confined fractured-rock aquifer in contact with the unconfined basin-fill aquifer beneath the Truckee River. The well initially discharged $600 \mathrm{gpm}$, but decreased to $570 \mathrm{gpm}$ after 3 hours and $500 \mathrm{gpm}$ after the first 24 hours of pumping. Two observation wells at distances of 220 and $1,250 \mathrm{ft}$ from site 29 were monitored. Both observation wells were screened in volcanic rock. The fourth aquifer test was made on June 17, 2002, at site 23 using the constant-drawdown, declining-discharge test (Jacob and Lohman, 1952). Discharge from the flowing stock well began at $50 \mathrm{gpm}$ and decreased to $48 \mathrm{gpm}$ in the first 20 minutes of monitoring. The 48 -gpm rate of discharge remained constant during 3 additional hours of monitoring.

Water-quality samples were collected to evaluate suitability of ground water from the study area as a source of drinking water. The stable isotope composition and chloride concentrations were used to evaluate mixing between ground water and surface water and to evaluate ET losses from recharge areas and volumes of recharge. Ground-water samples were collected from 11 wells in the Tracy Segment (sites 19-23, $26,30,31,40,49$, and 53; fig. 2) during 2001-03 following standard USGS sampling procedures available online at http://pubs.water.usgs.gov/twri9A (U.S. Geological Survey, variously dated). Samples from one well (site 23) were collected from natural artesian flow and all other samples were collected either using the submersible pump dedicated to each domestic or production well or a portable sampling pump. A minimum volume equivalent to three times the casing volume was used to field rinse sample tubing and to purge the casing and annular space of water that may have been affected by casing material.

Ground-water discharge was passed through an instrumented flow-through chamber to measure temperature, dissolved oxygen, $\mathrm{pH}$, and specific conductance. The composition of well water was assumed to be stable when three successive measurements of temperature, $\mathrm{pH}$, and specific conductance, taken at intervals of 5 minutes or more, differed by less than $0.5^{\circ} \mathrm{C}, 0.1$ standard $\mathrm{pH}$ unit, and $10 \mu \mathrm{S} / \mathrm{cm}$, respectively. Alkalinity was determined in the field using incremental titration with sulfuric acid on an aliquot of filtered sample water (Radtke and others, 1998, chapter 6.6). Ground-water samples for laboratory analyses were processed according to protocols described in Wilde and others (1999, chapter A5). Samples for dissolved trace elements and major cations were filtered through a 0.45 -micron capsule filter into acid-washed, field-rinsed polyethylene bottles that were then acidified with ultra pure nitric acid to a $\mathrm{pH} \leq 2$. Samples for dissolved nutrients and major anions were passed through the same capsule filter into field-rinsed polyethylene bottles. Nutrient samples were chilled on ice to $4^{\circ} \mathrm{C}$. Samples for mercury analysis were collected without filtration in acid-washed glass bottles and acidified with hydrochloric acid to a $\mathrm{pH} \leq 2$. Samples collected for analysis of dissolved radon gas were collected with a syringe through a septum in the sample line. A $10-\mathrm{mL}$ sample was slowly withdrawn and then injected into a glass vial containing liquid-scintillation solution and shaken for 30 seconds. Unfiltered samples for hydrogen and oxygen isotopes were collected in glass bottles with polyseal conical caps.

Surface-water samples were collected in 2001 at streamflow-gaging stations (sites 13-15, and site 17; table 1) along

Table 2. Transmissivity of bedrock estimated by pumped-aquifer tests, Tracy Segment Hydrographic Area, west-central Nevada

\begin{tabular}{clccc}
\hline $\begin{array}{c}\text { Site number } \\
\text { (fig. 2) }\end{array}$ & Dates of test & Test duration (hours) & $\begin{array}{c}\text { Average discharge rate, } \\
\text { (gallons per minute) }\end{array}$ & $\begin{array}{c}\text { Transmissivity } \\
\text { (feet squared per day) }\end{array}$ \\
\hline 23 & June 17, 2002 & 3.8 & 48 & 3,000 \\
29 & April 5-7, 2002 & 72 & 510 & 400 \\
32 & March 13, 1996 & 5.9 & 260 & 2,000 \\
42 & April 25-28, 2001 & 72 & 375 & 10,000 \\
\hline
\end{tabular}


the Truckee River (fig. 2) for determination of stable isotopes of water and specific conductance, using a nonisokinetic dipsampling method (Wilde and others, 1999, chapter A4, p. 49).

Nutrient and radon samples were shipped overnight to the USGS National Water-Quality Laboratory (NWQL) in Denver, Colorado; nutrient samples were shipped in coolers with ice. Major ion, trace element, and mercury samples also were shipped to the NWQL. The NWQL follows quality-assurance procedures described in Pritt and Raese (1995). Hydrogen and oxygen isotope samples were shipped to the USGS Isotope Fractionation Laboratory in Reston, Virginia, whose qualityassurance procedures are described by Coplen (2000).

Unsaturated-sediment samples were collected from 0.5 to $2 \mathrm{ft}$ intervals in six boreholes (sites 5-10; table 1) drilled to $26 \mathrm{ft}$ below land surface. Chloride concentrations were determined for 107 deionized-water extracts filtered from mixtures of one part water mixed with one part sediment by weight, after occasional shaking during at least a 24-hour period. Extracts were analyzed by ion chromatography at the USGS National Research Program laboratory in Menlo Park, California (Katherine Akstin, U.S. Geological Survey, written commun., 2002).

\section{Estimation of Ground-Water Recharge and Discharge}

Ground-water recharge and discharge in the Tracy Segment was last estimated using an empirical method known as the Maxey-Eakin method, which relates coefficients of meanannual precipitation to mean-annual ground-water discharge (VanDenburgh and others, 1973). These coefficients were developed for basins with climatic, pedologic, and land-cover characteristics that may differ from characteristics in the Tracy Segment; the significance of these differences is not known. New estimates of mean-annual precipitation (Berger and others, 1997; Daly and others, 1994) have introduced uncertainty to empirically estimated ground-water budgets. Perennial streamflow of the Truckee River may contribute additional recharge or receive ground-water discharge, consumptive use of water by vegetation may vary between HAs, and infiltration of intermittent streamflow has been identified as an important recharge process in the arid southwestern United States (for example, Scanlon, 1991; Izbicki and others, 1998 and 2002). Therefore, data for components of recharge and discharge also are evaluated herein along with two available empirical methods (VanDenburgh and others, 1973; Nichols, 2000) and two chloride-mass balance methods (Allison and Hughes, 1978; Claassen and others, 1986; Dettinger, 1989).

The Maxey-Eakin method relates precipitation required for recharge from each of five precipitation zones delineated from an early Nevada mean-annual precipitation map (Hardman, 1936, Hardman and Mason, 1949, p. 10) to equal ground-water discharge. The Nichols method uses multiplelinear regression to relate precipitation estimated from the Nevada 1997 precipitation-distribution map to ground-water discharge by phreatophytes, after adjusting for interbasin flow estimated by the Maxey-Eakin method (Nichols, 2000, p. C21; Harrill and others, 1988).

Chloride-mass balance methods are reconnaissance techniques that are useful to evaluate other recharge estimates and associated assumptions, because they integrate the longterm variability of precipitation and chloride concentrations into the recharge estimate. However, numerical simulations of recharge through typical heterogeneous sediments indicate that estimates using environmental tracers such as chloride are accurate only to within a factor of 3 or 4 (McCord and others, 1997, p. 1238). Chloride that is dissolved in precipitation is assumed to be the only source of chloride in ground water, but other potential sources include soluble evaporite minerals, connate water, and anthropogenic sources (for example, wastewater leachate and deicing salts). Estimation of ground-water recharge by chloride-mass balance is described by the generalized equation (Allison and Hughes, 1978):

$$
R=P \times\left(C l_{p} / C l_{r}\right)
$$

where

$R \quad$ is recharge in acre-feet per year;

$P \quad$ is precipitation, in acre-feet per year;

$\mathrm{Cl}_{\mathrm{p}} \quad$ is chloride concentration of bulk precipitation, in milligrams per liter; and

$\mathrm{Cl}_{\mathrm{r}} \quad$ is chloride concentration of recharge water (either pore water or ground water), in milligrams per liter.

The method assumes that the ratio of average chloride concentration dissolved in precipitation (rain, snow, and air-borne particulate chloride) relative to the concentration in moisture that has infiltrated beneath the effective ET depth is equal to the fraction of precipitation that was not consumed by ET and therefore, is available to recharge ground water. Concentrations of chloride in 24 samples of bulk precipitation collected in and near Spanish Springs Valley (fig. 1) in 1992-93 ranged from 0.07 to $1.3 \mathrm{mg} / \mathrm{L}$ and the average concentration was 0.38 $\mathrm{mg} / \mathrm{L}$ (Berger and others, 1997, p. 46). The average concentration of chloride dissolved in 75 precipitation samples collected from 32 sites statewide in Nevada from 1981-83 was 0.45 $\mathrm{mg} / \mathrm{L}$ (Dettinger, 1989, p. 62). An average value of $0.4 \mathrm{mg} / \mathrm{L}$ was assumed to be representative of chloride concentrations in precipitation for the Tracy Segment.

Measurement of chloride dissolved in ground water provides estimates of the average proportion of precipitation that contributes to the sampled ground water (Claassen and others, 1986; Dettinger, 1989). Measurement of chlorideconcentration profiles of pore water in unsaturated sediments provides an estimate of recharge at point locations. Chloride profiles have been used to estimate the effective ET depth and the length of time chloride has been accumulating. In addition to the generalized assumptions of chloride-mass balance, the chloride-profile approach assumes that land surface was not affected by erosion and that chloride was transported conservatively (negligible dispersion) beneath the effective ET depth (Allison and Hughes, 1978; Scanlon, 1991; Allison 
and others, 1994; Phillips, 1994; Maurer and Thodal, 2000). Unsaturated-sediment samples were collected from 0.5 to $2 \mathrm{ft}$ intervals in six boreholes drilled to $26 \mathrm{ft}$ below land surface (sites 5-10; fig. 2). Chloride concentrations were determined for 107 deionized-water extracts filtered from mixtures of one part water mixed with one part sediment by weight, after occasional shaking during at least a 24 -hour period. Extracts were analyzed by ion chromatography at the USGS National Research Program laboratory in Menlo Park, California (Katherine Akstin, U.S. Geological Survey, written commun., 2002).

An annual water balance for recharge areas assumes that the difference between mean-annual volumes of precipitation $(P)$ and the sum of mean-annual runoff $(R), \mathrm{ET}$, and changes in storage $(\Delta \mathrm{S})$ is equal to deep percolation $(D)$ that eventually recharges ground water (Gee and Hillel, 1988, p. 258):

$$
D=P-(R+E T+\Delta S) .
$$

Three distributions of mean-annual precipitation were considered as input to recharge in the Tracy Segment (VanDenburgh and others, 1973; Smith and others, 2001; and Berger and others, 1997). Runoff was estimated by using the area of a basin that lies within each altitude zone and precipitation-altitude curves developed for elevation zones of selected gaged basins in Nevada (Moore, 1976). ET was estimated by the Bowen-ratio method, which is based on energy fluxes into and out of the soil, vegetation, and atmosphere in the immediate vicinity of instrumented sites. An energy balance approach is used because energy is used to convert water from liquid to vapor and to transfer the vapor to the atmosphere (Nichols, 1992; Laczniak and others, 1999; Berger and others, 2001). Annual rates of ET were subtracted from mean annual rates of precipitation in each altitude zone and the remainder (expressed in feet per year) was multiplied by the acreage in the altitude zone to estimate moisture available for recharge and intermittent runoff in acre-feet per year. Changes in storage of moisture in unsaturated sediments $(\Delta S)$ were considered qualitatively by examining changes in soil moisture measured by a neutron moisture probe over time.

Evaluation of recharge $(R)$ from intermittent runoff was estimated as the product of stream channel wetted area (A), infiltration rate (I), streamflow frequency (F), and duration (D):

$$
R=A \times I \times F \times D .
$$

Area of wetted stream channel was estimated using a digital elevation model (U.S. Geological Survey, 2002) and a geographical information system to estimate total length of ephemeral channels and average channel width was assumed to be $10 \mathrm{ft}$. Rates of infiltration were estimated on November 11, 2001, for a 3,000 ft reach of Long Valley Canyon Creek that receives ground water from several springs. Streamflow was measured at the upper-most cross section of the stream, using a 3-in. modified Parshall flume and streamflow had completely infiltrated at $3,000 \mathrm{ft}$ downstream of the first cross section. Infiltration was computed as the volume of streamflow lost through the wetted streambed area. Temperature-pro- file time-series data have been used as a marker of intermittent streamflow and to estimate rates of infiltration (Lapham, 1989) from time lag between temperature changes with depth. "Permeability" of soils mapped in ephemeral streambeds within the Tracy Segment range from 0.04 to $40 \mathrm{ft} /$ day, with 4-12 ft/day reported most frequently (Archer, 1990, p. 261270; Baumer, 1983, p. 547-575).

Frequency of intermittent streamflow was estimated using linear regression analysis of data from the National Weather Service precipitation station near Virginia City and the USGS crest-stage gaging station at Long Valley Canyon Creek (site 18, table 1). Most peak streamflows were recorded during winter months when precipitation accumulates as snow prior to melting indicating that cumulative precipitation (the amount of precipitation to accumulate prior to, and including the day of reported runoff) be considered in this analysis.

Duration of intermittent streamflow varies depending on the type of runoff event and all peak-discharge events except three were recorded during December through March. Intense summer thunderstorms typically generate short-term localized streamflow whereas winter storms usually are more regional and may accumulate and store several inches of water as snow. Warm winter storms, especially ones that follow snowstorms, are widely known to cause severe flooding attributed to "rain on snow events." The largest peak discharge recorded at site 18 was on February 19, 1986, (Pupacko and others, 1988, p. 219) when flooding affected Carson City and Douglas, Lyon, Storey, and Washoe Counties and increased precipitation from 75 percent of average on February 1 to about 150 percent of average on March 1 (James, 1986). Significant streamflow $\left(290 \mathrm{ft}^{3} / \mathrm{s}\right)$ was measured by USGS personnel on February 20, 1986, (U.S. Geological Survey, written commun., 2002) indicating duration of intermittent streamflow can exceed one day.

Methods used to estimate ground-water discharge include the same empirical methods used to estimate recharge because they assume recharge and discharge are equal (Maxey and Eakin, 1949; Nichols, 2000). Ground-water discharge also was calculated by adding estimated volumes of ground water discharged by pumping and flowing wells, by seepage to the Truckee River, by springs, and by phreatophytic ET. Groundwater pumpage was estimated from water rights approved by the Nevada State Engineer (Mark Beutner, Nevada Division of Water Resources, written commun., 2000) plus domestic pumpage estimated by counting houses within the Tracy Segment using digital aerial orthophotographs taken in 1994 and estimating an average rate of 0.5 acre-ft/yr per household (Maurer, 1997, p. 25). Houses in areas where community water supplies are available were not counted. Discharge to the river was estimated by data collected for past seepage studies and by comparing streamflow gaged at the upstream HA boundary (site 13) to the downstream boundary (sum of streamflow gaged at sites 16 and 17; fig. 2). Discharge from springs was estimated by using inventories of topographic maps and reported volumes of water applied for on water rights from springs (Mark Beutner, Nevada Division of Water Resources, written commun., 2000). Consumptive water-use 
by phreatophytes and crops in the Tracy Segment was estimated by determining the area of different plant communities and applying the appropriate ET rates to those areas. In this report, ET from recharge areas is based on micrometeorological measurements and ET by phreatophytes is based on published rates of ground-water discharge. Areas of phreatophytes were reported by Caicco (1998) and mapped from satellite imagery (Jennings and Scott, 1997).

Ground-water flow across hydrographic boundaries also can be significant to ground-water budget calculations. Ground-water inflow to and outflow from the Tracy Segment were estimated using Darcy's Law and hydraulic properties of the aquifer beneath the HA boundary and between groundwater sites in that vicinity.

\section{Description of Study Area}

\section{Geographic Setting}

The Tracy Segment is a $285 \mathrm{mi}^{2}$ HA located in the Truckee River Basin between two USGS stream-gaging stations, Truckee River at Vista (10350000) and Truckee River at Wadsworth (10351650; table 1). The Tracy Segment is bounded by the crest of the Virginia Range to the south, and the Pah Rah Range to the north. Pond Peak is the highest peak in the Pah Rah Range at about 8,000 ft and Orleans Hill is the highest peak on the western boundary at about 7,400 ft. The Pah Rah Range may be a northward continuation of the Virginia Range separated by the relatively narrow Truckee River canyon (Bonham and Papke, 1969, p. 51). Adjacent HAs include the Truckee Meadows to the west, Spanish Springs Valley, Warm Springs Valley, and Dodge Flat to the north, the Fernley Area to the east, and Dayton Valley and Churchill Valley to the south (Rush, 1968; Cardinalli and others, 1968).

About $30 \mathrm{mi}$ of the Truckee River are within the Tracy Segment and U.S. Interstate 80 runs roughly parallel to the river, providing access to and from the Reno/Sparks metropolitan area to the west and Fernley to the east. The Truckee River originates at the outlet of Lake Tahoe in the Sierra Nevada almost 2,000 ft above Reno, and drops 300 $\mathrm{ft}$ through the Tracy Segment from 4,370 $\mathrm{ft}$ above sea level at the streamflow-gaging station at Vista to $4,070 \mathrm{ft}$ at the streamflow-gaging station near Wadsworth. During the 30-yr period from October 1971 through September 2000, average annual discharge measured at the streamflow-gaging station at Vista was about 634,000 acre-ft/yr and discharge measured at Wadsworth was about 477,000 acre-ft/yr. Diversions from the Truckee River at Derby Dam to the Truckee Canal averaged about 154,000 acre-ft/yr during the same period. Ten rockdiversion dams have been constructed to support canals that irrigate about 760 acres of agricultural land along the river within the Tracy Segment. Almost 2,400 acres are decreed for irrigation of agricultural land within the Tracy Segment and about 2,500 acres are decreed for on the Pyramid Lake Indian Reservation (Federal Water Master, written commun., 2003).

Land use within the Tracy Segment is predominantly rangeland with ranches and rural residences located along the Truckee River. Areas of residential and industrial land uses are concentrated in the Virginia Highlands, Lockwood, Mustang and Wadsworth (fig. 1). The Tracy Power Station, located about 17 mi downstream from Reno, is an integrated gasification and combined cycle system capable of burning either coal gas or natural gas. Light industrial and manufacturing developments have been established between Patrick and Clark.

\section{Climate and Vegetation}

The Tracy Segment is in the rain shadow of the Sierra Nevada, resulting in an arid to semiarid, high desert climate. Most of the annual precipitation falls during the winter months as both snow and rain that originates from evaporated Pacific Ocean moisture. Moist air from the west cools and water vapor condenses as it rises above the western slope of the Sierra Nevada, where most falls as precipitation. This phenomenon is commonly referred to as the rain shadow effect, which reduces amounts of precipitation leeward of the Sierra Nevada. Intense thunderstorms, typically of limited areal extent, occur infrequently during summer months.

From 1971 through 2000, annual precipitation recorded at National Weather Service stations in and near the Tracy Segment (table 3) averaged from about 5.3 in. at Lahontan Dam (NWS2) to about 14.3 in. at Virginia City (NWS6; National Climate Data Center, accessed July 1, 2003 at http://www. wrcc.dri.edu/). One nearby station (NWS1) located at an altitude of about 7,200 ft was estimated by the Nevada State Climatologist to average 15.4 in. during 1961-90, but its operation has since been discontinued. Droughts have affected western Nevada, both during the late 1980's through the early 1990 's and during the first three years of data collection for this study. Precipitation was above average in 1982, 1983, 1996, and 1998 (fig. 3A) and cumulative departure from average is shown in figure $3 \mathrm{~B}$.

Temperatures in the high desert of western Nevada can vary as much as $40^{\circ} \mathrm{F}$, both seasonally and on many days, principally because of the low relative humidity. Mean-annual temperatures in and near the Tracy Segment ranged from about $49^{\circ} \mathrm{F}$ near Virginia City to $56^{\circ} \mathrm{F}$ at Lahontan Dam. Daily high temperatures during summer months are warm, normally ranging from $80^{\circ} \mathrm{F}$ to $90^{\circ} \mathrm{F}$ and on individual days can exceed $100^{\circ} \mathrm{F}$. Daily low temperatures during the summer months normally range from $52^{\circ} \mathrm{F}$ to $68^{\circ} \mathrm{F}$. Winters are cold with daily low temperatures ranging from $20^{\circ} \mathrm{F}$ to $30^{\circ} \mathrm{F}$ (National Climate Data Center, accessed July 1, 2003, at http://www.wrcc.dri.edu/).

Vegetation is typical of the high desert of the western Great Basin with the distinction of having a riparian corridor along the Truckee River. The distribution of dominant plant communities has been mapped from satellite imagery (Jen- 
Table 3. Precipitation data, normalized to 1971-2000, and selected estimates for stations in and near the Tracy Segment Hydrographic Area, west-central Nevada

\begin{tabular}{|c|c|c|c|c|c|c|}
\hline \multirow{4}{*}{$\begin{array}{l}\text { Map } \\
\text { label } \\
\text { (figs. } 1 \\
\text { and 2) }\end{array}$} & \multirow{4}{*}{$\begin{array}{l}\text { Altitude } \\
\text { (feet } \\
\text { above } \\
\text { sea } \\
\text { level) }\end{array}$} & \multicolumn{5}{|c|}{$\begin{array}{c}\text { Mean annual precipitation } \\
\text { (inches) }\end{array}$} \\
\hline & & \multirow{3}{*}{$\begin{array}{c}\text { Normalized to } \\
\text { the period } \\
1971-2000\end{array}$} & \multicolumn{3}{|c|}{ Nevada Mean Annual Precipitation Map } & \multirow{3}{*}{ Regression ${ }^{3}$} \\
\hline & & & \multirow{2}{*}{$1965^{1}$} & \multicolumn{2}{|c|}{$1997^{2}$} & \\
\hline & & & & Cell & Interpolated & \\
\hline 1 & 6,017 & ${ }^{4} 11.2$ & $12-15$ & 16.1 & 15.5 & 10.8 \\
\hline 2 & 7,075 & 49.6 & $12-15$ & 14.0 & 18.7 & 13.3 \\
\hline 3 & 5,200 & ${ }^{4} 6.2$ & $8-12$ & 8.4 & 12.4 & 8.8 \\
\hline 4 & 5,953 & ${ }^{4} 8.4$ & $8-12$ & 13.2 & 11.4 & 10.6 \\
\hline NWS1 & 7,200 & ${ }^{5} 15.4$ & $12-15$ & 9.7 & 18.2 & 13.6 \\
\hline NWS2 & 4,150 & 65.3 & $<5$ & 6.4 & 5.7 & 6.3 \\
\hline NWS3 & 4,400 & 67.5 & $5-8$ & 9.6 & 8.6 & 6.9 \\
\hline NWS4 & 4,360 & 67.4 & $5-8$ & 10.6 & 8.8 & 6.8 \\
\hline NWS5 & 3,980 & 67.7 & $8-12$ & 16.3 & 9.0 & 5.9 \\
\hline NWS6 & 6,340 & ${ }^{6} 14.3$ & $12-15$ & 14.9 & 23.4 & 11.6 \\
\hline NWS7 & 4,200 & ${ }^{6} 6.0$ & $5-8$ & 7.0 & 7.1 & 6.4 \\
\hline \multicolumn{7}{|c|}{$\begin{array}{l}\text { IValue determined by projecting location of precipitation stations on paper copy of the } 1965 \text { Nevada precipitation map } \\
\text { (Hardman, 1965). }\end{array}$} \\
\hline \multicolumn{7}{|c|}{$\begin{array}{l}\text { 2Precipitation estimated from digital version of the } 1997 \text { Nevada precipitation map (Smith and others, 2001), gener- } \\
\text { ated using the analytical model, Parameter-elevation Regressions on Independent Slopes Model (PRISM; Daly and others, } \\
\text { 1994). Values in column labeled "Cell" is that assigned to the } 2 \text { kilometer by } 2 \text { kilometer grid cell that corresponds with the } \\
\text { station location and values in the column labeled "Interpolated" is an interpolation of values associated with nine grid cells } \\
\text { closest to the station location. }\end{array}$} \\
\hline \multicolumn{7}{|c|}{${ }^{3}$ Values computed by precipitation $=(0.00241 \mathrm{x}$ altitude $)-3.71$ (Berger and others, 1997, p. 27$)$} \\
\hline \multicolumn{7}{|c|}{$\begin{array}{l}{ }^{4} \text { Bulk precipitation collected during water year } 2002 \text { (October } 2001 \text { through September 2002) and normalized to mean } \\
\text { annual precipitation reported for NWS6 for } 1971 \text { through } 2000 .\end{array}$} \\
\hline \multicolumn{7}{|c|}{${ }^{5}$ Estimated by James (1995) for 1961-1990 and assumed, to be equal to $1971-2000$ for purposes of this report. } \\
\hline
\end{tabular}

nings and Scott, 1997) and is shown in figure 4. A desert shrub community consists of a sparse mixture of sagebrush (Artemisia tridentata), rabbitbrush (Chrysothamnus spp.), shadscale (Atriplex confertifolia), and other low shrubs and perennial grasses, that covers about 66 percent of the area. The pinion-juniper community is made up of thinly-spaced juniper (Juniperus utahensis) and pinion (Pinus monphylla) trees interspersed with shrubs and perennial grasses at elevations higher than about $6,000 \mathrm{ft}$ (about 16 percent of area in the Tracy Segment). A salt desert scrub community, consisting of hop sage (Atriplex spinosa), shadscale, greasewood (Sarcobatus vermiculatus), and saltgrass (Distichylis stricta) occupies much of the lower elevations (about 14 percent of area). A lowland riparian plant community of shrub willow (Salix spp.), cottonwood (Populus fremontii ssp. fremontii) and greasewood integrate with low shrub and grasses along the Truckee River. During the mid-to-late 1800's, explorers and pioneers described the floodplain of the Truckee River downstream of the Truckee Meadows as a dense, nearly impenetrable forest of willows and cottonwood. Much of this riparian vegetation has been cleared for cropland. Beavers (Castor canadensis) reportedly were introduced to the area in the late 1940's to help reduce loss of water by ET from riparian vegetation (Caicco, 1998). Estimates of the area dominated by riparian vegetation from a survey of land cover in the Truckee River corridor (Caicco, 1998) are listed in table 4. About 600 acres of riparian area are described as disturbed, urban/industrial, or dominated by whitetop (Lepidium latifolium), an invasive weed (Caicco, 1998, p. 21-22).

\section{Hydrogeologic Setting}

The Tracy Segment is in a transitional zone between the Basin and Range and the Sierra Nevada physiographic provinces. The Sierra Nevada batholith intruded existing geology from the west about 90 million years ago (Ma). Widespread crustal extension which produced the block-faulted landscape of the Basin and Range to the east began about 17 Ma and continues to the present (Stewart, 1980, p. 73-77 and 105-110). The two provinces are separated by the north-south trending Sierra Nevada frontal fault zone; the northern end of this zone near Honey Lake, California either merges with or is truncated by northwest-trending faults believed to be related 

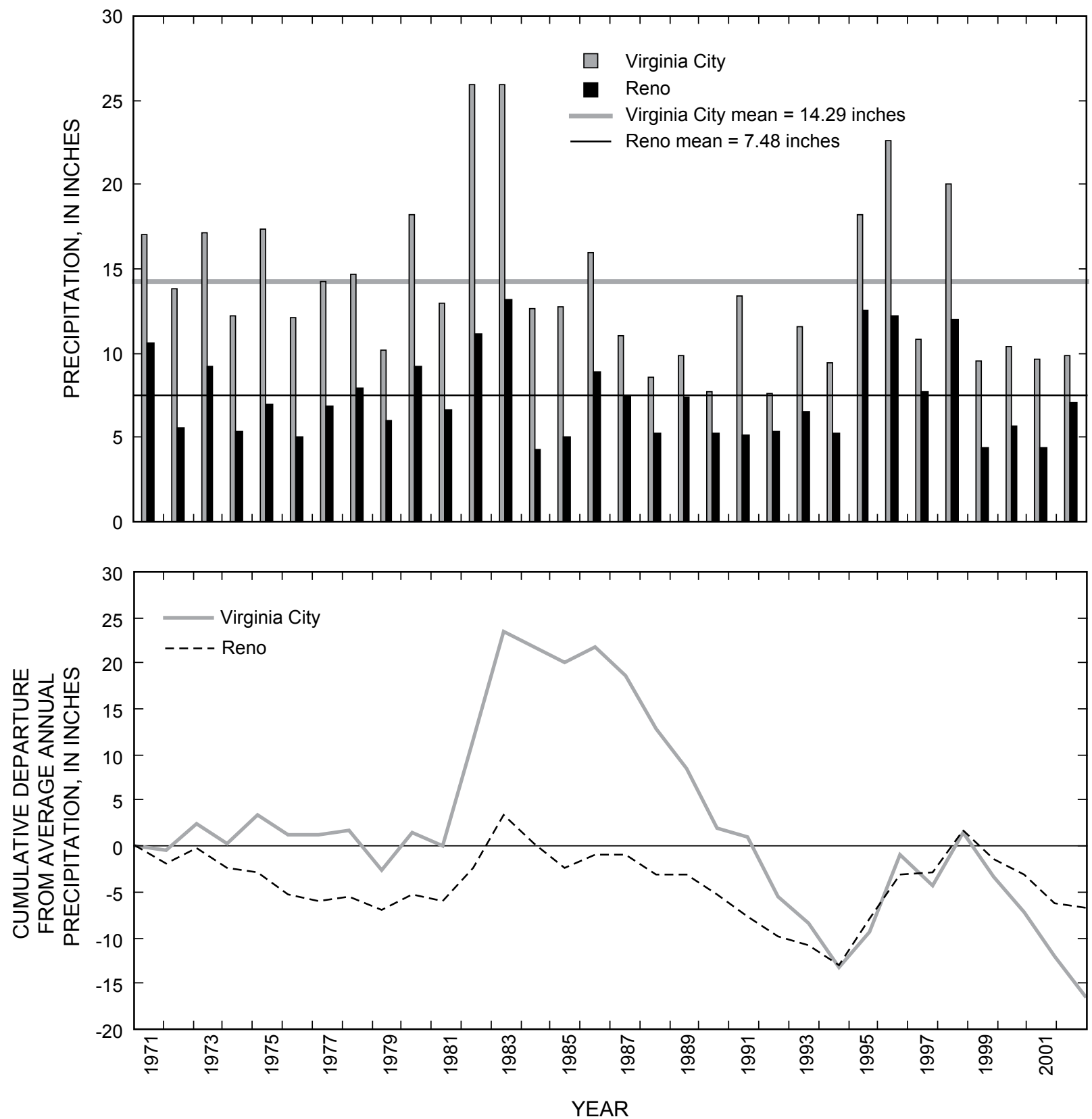

Figure 3. Annual precipitation and cumulative departure from average annual precipitation measured at Virginia City and Reno, west-central Nevada, 1971-2002. 
Table 4. Estimated vegetation and land classification coverage, Tracy Segment Hydrographic Area, west-central Nevada

[Symbol: -, estimates not reported]

\begin{tabular}{lcc}
\hline $\begin{array}{c}\text { Vegetation type or land classifica- } \\
\text { tion }\end{array}$ & $\begin{array}{c}\text { Area }^{1} \\
\text { (acres) }\end{array}$ & $\begin{array}{c}\text { Riparian } \\
\text { area }^{2} \\
\text { (acres) }\end{array}$ \\
\hline Upland shrub $^{3}$ & 122,100 & 200 \\
Pinion-juniper & 31,000 & 0 \\
Salt desert shrub & 25,300 & - \\
Urban/industrial & 3,400 & 100 \\
Agriculture & 1,900 & 700 \\
Riparian & 800 & - \\
Cottonwood & - & 200 \\
Willow shrub & - & 200 \\
Whitetop & & - \\
Disturbed & - & 400 \\
Low-flow channel & - & 100 \\
Vegetated streambed or cobble bars & - & 300 \\
Total (rounded) & 184,500 & 2,300
\end{tabular}

\footnotetext{
${ }^{1}$ Jennings and Scott, 1997.

${ }^{2}$ Caicco, 1998, p. 21-22.

${ }^{3}$ Dominant species include sagebrush (Artemisia tridentata), greasewood (Sarcobatus vermiculatus), and rabbitbrush (Chrysothamnus nauseosus).

${ }^{4}$ Lepidium latifolium, considered a noxious, non-native species.
}

to the Walker Lane (Bell, 1981, p. 35). Tectonic activity has uplifted mountains and down-dropped valley floors. Outcrops of metamorphic rocks are found at elevations of 4,000 $\mathrm{ft}$ or less whereas similar rocks in mountains to the west are found at elevations as high as $8,200 \mathrm{ft}$, indicating an average structural depression of the Tracy Segment of about 4,000 $\mathrm{ft}$ (Bonham and Papke, 1969, p. 51). Tectonic, volcanic, and fluvial processes have shaped the present-day landscape and have effectively obscured and eroded rocks older than about $240 \mathrm{Ma}$.

The two main hydrogeologic units in the Tracy Segment are bedrock and basin-fill deposits. Bedrock is further subdivided into the following four units (1) metamorphosed volcanic and sedimentary rocks of Triassic and Jurassic age, (2) shallow intrusive rocks of Tertiary age, (3) sedimentary rocks of Tertiary age, and (4) volcanic rocks of Tertiary and Quaternary age. Relatively impermeable, granitic rocks are believed to underlie the oldest exposed units. The degree of weathering, fracturing, and type of lithology can affect the rate of ground-water flow in bedrock aquifers, whereas grain size, degree of sorting, compaction, and cementation can affect rates of ground-water flow in basin-fill aquifers.

Figure 5 shows generalized distribution of hydrogeologic units in the Tracy Segment using digital versions of geologic mapping of Washoe, Storey, and Lyon Counties at a scale of 1:250,000 (Moore, 1969; Bonham and Papke, 1969). Prior to about $240 \mathrm{Ma}$, the Tracy Segment was an area of deep-water marine deposition with minimal tectonic activity (Stewart, 1980, p. 35-36). Marine sedimentary and volcanic rocks that accumulated under these conditions consist of flows, tuffs, and breccias interbedded with slates, sandstones, and conglomerates (Bonham and Papke, 1969, p. 7). These rocks were metamorphosed about $90 \mathrm{Ma}$ by granitic intrusions and the resulting metavolcanic and metasedimentary rocks occur as small (less than $2 \mathrm{mi}^{2}$ ), sparsely distributed outcrops. The only exposure of granitic rock within the Tracy Segment is one small outcrop (less than $2 \mathrm{mi}^{2}$ ) in Pierson Canyon that may be as young as $30 \mathrm{Ma}$ (Bonham and Papke, 1969, p. 9). However, the entire Tracy Segment probably is underlain at depth by granitic, metasedimentary, and metavolcanic rocks.

Throughout the Tracy Segment metavolcanic, metasedimentary, and granitic bedrock are unconformably overlain by thick sequences of Tertiary volcanic rock that erupted from about 20 Ma until as recently as 10,000 years ago. The most prevalent volcanic rocks are composed of andesite, basalt, and rhyolite found as thick (greater than 3,000 ft) sequences of flows, flow breccias, tuffs, tuff-breccias, and associated shallow intrusions (Bonham and Papke, 1969, p. 28). Intercalated with the volcanic rocks are sedimentary lenses of alluvium, diatomite, sandstone, conglomerate, and shale (Bonham and Papke, 1969, p. 31-37). Basalt flows and associated intrusive rocks are the predominant hydrogeologic unit in the Pah Rah Range. These Tertiary rocks are young (generally less than 10 $\mathrm{Ma}$ ), with some as young as one million years. Younger flows average less than 20 -ft thick but aggregate thickness locally may exceed 1,000 ft (Bonham and Papke, 1969, p. 39-40). Volcanism that continued until as recently as 10,000 years ago, primarily produced andesite and basalt flows which are found south of Clark in the Virginia Range and northeast of Derby Dam in the Pah Rah Range (Rose, 1969, p. 22; fig. 1).

Basin-fill deposits consisting of alluvium and colluvium accumulated during the past two million years and overlie all of the older hydrogeologic units. Basin-fill deposits are thickest along and beneath the Truckee River and in tributary drainages. The deposits are primarily of volcanic origin and accumulated in upland areas as poorly sorted coarse alluvial fan and pediment gravels enclosed in a sandy matrix. The Truckee River has reworked and redeposited some of the alluvial fan and pediment gravels as flood plain deposits. Older deposits have been covered with Tertiary-age volcanic flows. Cobbles and boulders as large as six feet in diameter are common in these deposits (Rose, 1969, p. 23), evidence of a wetter climate when a large lake covered the Truckee Meadows just upstream of the Tracy Segment (Reheis, 1999). Lacustrine deposits consist of clays, silts, sands, and gravels that grade from fine to coarse from the interior to the margins of these ancient lake basins (Bonham and Papke, 1969, p. 42). During its highest stands, ancient Lake Lahontan accumulated sediments along the length of the Truckee River in the Tracy Segment from more than 1 million to about 11,000 years ago (Reheis, 1999). The high stand of Lake Lahontan was about $4,380 \mathrm{ft}$ and deposits are mostly well-sorted and well-bedded sand with minor amounts of gravel, silt, and tufa (Rose, 1969, 


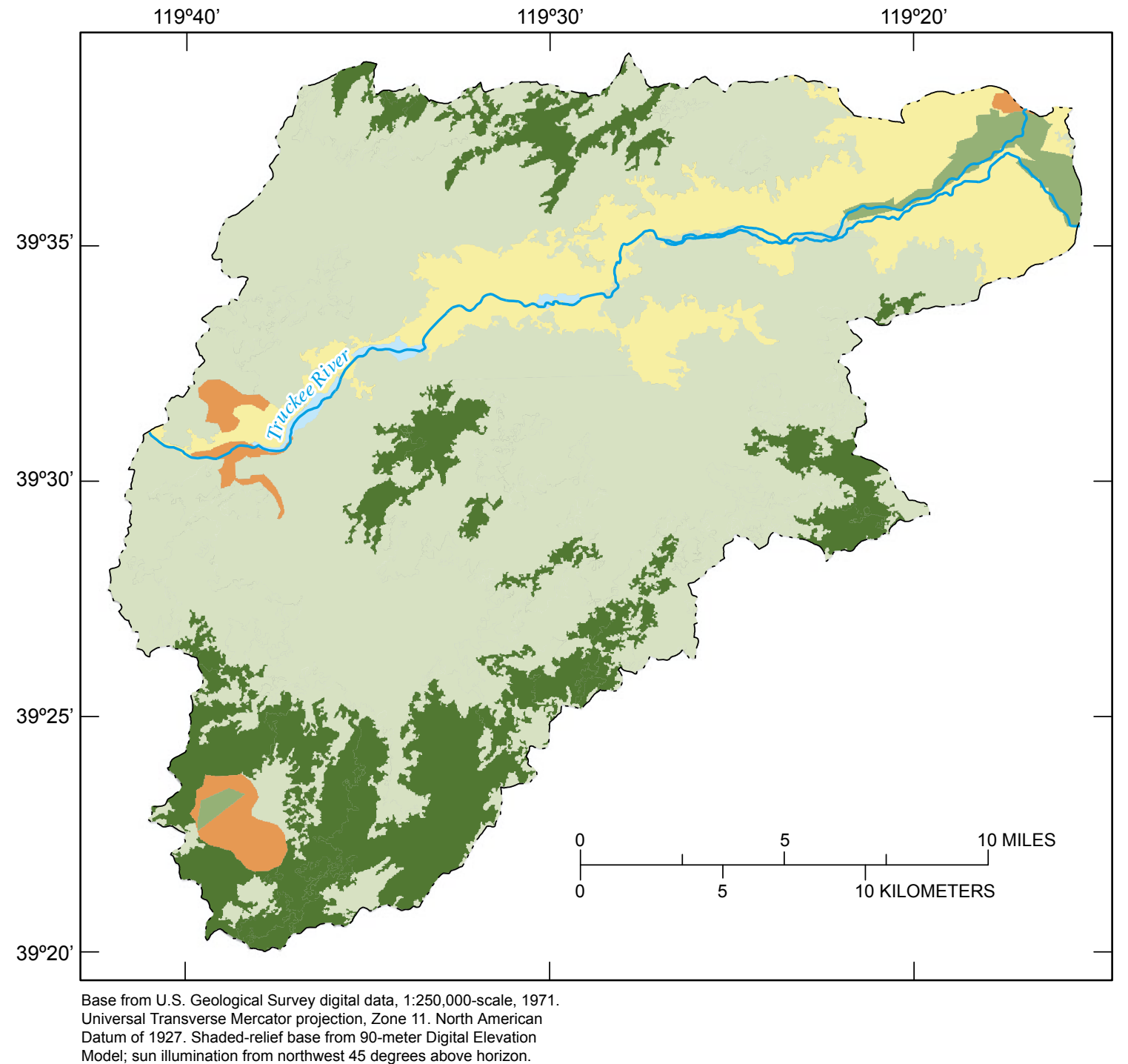

EXPLANATION

\section{Land cover}

\begin{tabular}{|c|c|}
\hline Pinion-juniper forest & Agriculture \\
\hline Desert shrub & Lowland riparian \\
\hline Salt desert scrub & Urban \\
\hline
\end{tabular}

- - H - Hydrographic-area boundary

Figure 4. Generalized distribution of dominant land cover, Tracy Segment Hydrographic Area, west-central Nevada (Jennings and Scott, 1997). 


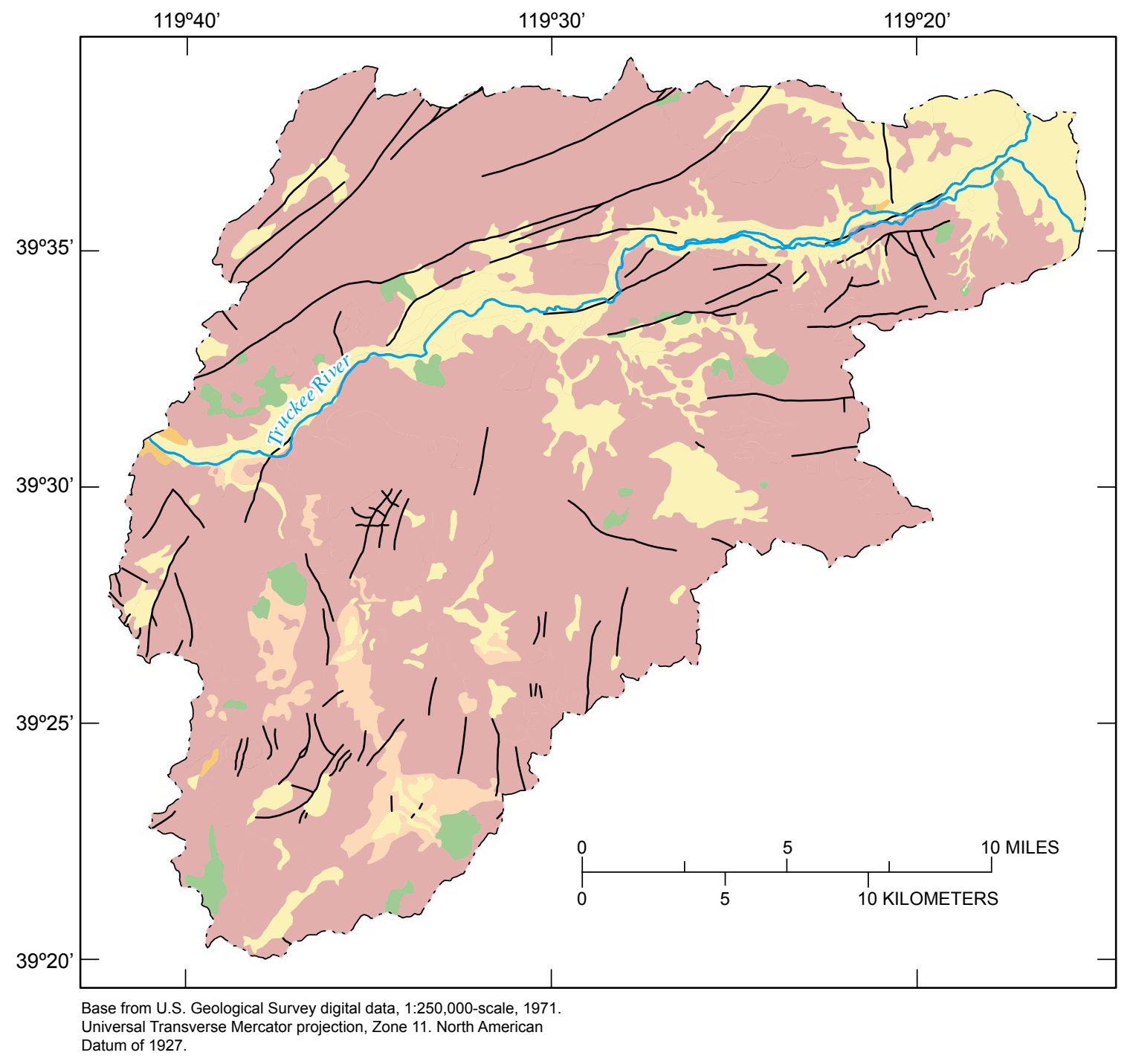

EXPLANATION

Geology

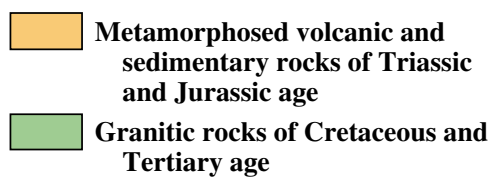

Sedimentary rocks of Tertiary age

— - Hydrographic-area boundary

Fault

\section{Volcanic rocks of Tertiary} and Quaternary age_-Includes flows, breccias, and tuffs of basaltic, andesitic, and rhyolitic composition

Basin-fill deposits of Quaternary age- Consists of unconsolidated clay, silt, sand, gravel, and boulders along the Truckee River canyon and its tributaries

Figure 5. Generalized geologic units and structural features of Tracy Segment Hydrographic Area, west-central Nevada. 
p. 23). Sediment transported by the Truckee River from the Sierra Nevada is abundant in lacustrine deposits.

\section{Physical Properties of Hydrogeologic Units}

Hydrogeologic units within the Tracy Segment are basinfill deposits and permeable bedrock. Consolidated rocks that form mountain blocks also underlie partly-consolidated and unconsolidated sediments that make up basin-fill deposits. Bedrock hydrogeologic units predominantly are andesite, basalt, and rhyolite volcanic rocks that have secondary permeability through fractures, zones of weathered rock and rubble, and intercalated sedimentary lenses. Permeability in this unit is called secondary because the bulk of the rock matrix is relatively impermeable, but ground water will move into and through interconnected fractures, voids, and permeable lenses. Frequently, the contact between individual flows also is permeable. Basin-fill hydrogeologic units consist of unconsolidated sediments that have accumulated in bedrock basins and along the flood plain of the Truckee River. Older sediment deposits (more than about $2 \mathrm{Ma}$ ) may have become partly consolidated due to compaction, mineralization, and solute precipitation. Basin-fill deposits have low permeability when composed of fine-grained deposits, such as clay and silt, and are moderately permeable when composed of coarse-grained but poorly sorted material, such as found in alluvial fans. Deposits are highly permeable when composed of coarsegrained and well sorted material, such as deposits found along the Truckee River flood plain.

More than 500 well drillers' reports have been filed for wells drilled in the Tracy Segment. Total depth reported for 490 wells ranged from 8 to $1,900 \mathrm{ft}$ below land surface; half of these depths are $250 \mathrm{ft}$ or less. Static water levels reported for 432 wells ranged from about $25 \mathrm{ft}$ above land surface to $1,100 \mathrm{ft}$ below land surface, with half of the static levels greater than $64 \mathrm{ft}$ below land surface. Well yields reported for 249 wells ranged from 0 to $1,000 \mathrm{gal} / \mathrm{min}$, with half yielding $20 \mathrm{gal} / \mathrm{min}$ or less. Reported values of specific capacity for 45 wells ranged from 0.02 to $20 \mathrm{gal} / \mathrm{min} / \mathrm{ft}$, half of these values were less than $0.4 \mathrm{gal} / \mathrm{min} / \mathrm{ft}$. The mean transmissivity based on these specific capacity values was $480 \mathrm{ft}^{2} / \mathrm{d}$ (Heath, 1983, p. 61).

Estimates of the transmissivity of bedrock hydrogeologic units were made from four aquifer tests (table 2) using well sites 23, 29, 32, and 42 (fig. 2). On the basis of these analyses, transmissivity of volcanic rock units ranged from 400 to $10,000 \mathrm{ft}^{2} / \mathrm{d}$. Many other exploratory, test, domestic, and production wells have been constructed in bedrock in the Tracy Segment, and more than 100 domestic wells have been constructed in a residential area known locally as the Virginia Highlands (fig. 1). Well drillers' reports for this area indicated basin-fill deposits are as thick as $280 \mathrm{ft}$. More than half of these wells penetrated less than $45 \mathrm{ft}$ of basin fill and most wells were drilled deep enough to intercept ground water in underlying bedrock. Seventeen test wells with depths rang- ing from 250 to $600 \mathrm{ft}$ below land surface were drilled into bedrock near Martin Canyon (fig. 1; Consulting Services Associates, Inc., 1997). Eight of these wells yielded less than $10 \mathrm{gal} / \mathrm{min}$ and were subsequently abandoned. Yields ranged from 40 to $300 \mathrm{gal} / \mathrm{min}$ in the remaining nine wells, which had static water levels ranging from 52 to $326 \mathrm{ft}$ below land surface. Specific capacity for volcanic rocks ranged from $<0.01$ for the "dry" wells to $5.9 \mathrm{gal} / \mathrm{min} / \mathrm{ft}$; corresponding transmissivity values ranged from $<300$ to $1,800 \mathrm{ft}^{2} / \mathrm{d}$. Bedrock near the Olinghouse Mine near Pierson Canyon had hydraulic conductivity values that ranged from 0.026 to $2.4 \mathrm{ft} / \mathrm{d}$ (fig. 1; PTI Environmental Services, 1997, p. 9).

The Truckee River flood plain is the most extensive basin-fill hydrogeologic unit and consists of fluvial deposits. Because the river is confined to a relatively narrow canyon through the upstream two-thirds of the study area, basin-fill deposits are limited both in width and depth. According to well drillers' reports, basin-fill deposits typically are little more than 100-ft thick in the western reach of the study area and 400-ft thick or less in the central reach. Thickness of basinfill deposits near Wadsworth is greater than $400 \mathrm{ft}$, although few wells were completed to this depth within this hydrogeologic unit. A geophysical model of basin-fill sediments in the Wadsworth area indicates bedrock is steeply down-dropped near the boundary with the Fernley Area and Dodge Flat HAs, and basin-fill deposits are as much as 3,000-ft thick (Pohll and others, 2001, p. I-21). Static water levels are less than $10 \mathrm{ft}$ below land surface near the river and typically less than 100 $\mathrm{ft}$ throughout this hydrogeologic unit. Static water levels in basin-fill deposits located away from the Truckee River flood plain typically are $50 \mathrm{ft}$ or more; however, most ground water is found only in fractured consolidated rock.

\section{Hydrology}

Primary sources of water to the Tracy Segment are the Truckee River and precipitation. Infiltration of precipitation from streamflow along the river and its tributaries are the most important sources of ground-water recharge. Ground-water inflow from adjacent HAs also is a source of ground water to the Tracy Segment. Streamflow in the Truckee River and Truckee Canal and ET are the primary outflow from the Tracy Segment and outflows of ground water include withdrawals from wells, discharge to the Truckee River and to springs, and transpiration by phreatophytes. Ground water also discharges from the Tracy Segment to adjacent HAs.

\section{Annual Precipitation}

Infiltration of precipitation that falls within the Tracy Segment is the most important source of ground-water recharge. The amount of precipitation that falls will vary annually depending on weather patterns (fig. 3A), as well as spatially (table 3 ) due to orographic effects, including the rain 
shadow of the Sierra Nevada. Annual total precipitation and cumulative departure from mean annual precipitation reported by National Climate Data Center for Virginia City and Reno are shown in figures $3 \mathrm{~A}$ and $3 \mathrm{~B}$, respectively. Altitudes of these stations range from 3,980 (NWS5) to 7,200 ft (NWS1) and normalized precipitation ranges from 5.3 in. at NWS2 to 15.4 in. at NWS1. During water years 2001 and 2002 (WY01-02) precipitation recorded at National Weather Service stations near the Tracy Segment ranged from 28 percent of the 1971-2000 30-yr average at NWS3 (2.13 in.; WY01) to 101 percent at NWS4 (7.45 in.; WY02). Average percentages of 30-yr average precipitation for sites NWS2 through NWS7 are 45 percent in WY01 and 74 percent in WY02. Annual precipitation recorded at 11 precipitation stations located in or near the Tracy Segment (fig. 1) was normalized to the period 1971-2000 and is listed in table 3.

The total average amount of precipitation that falls in the Tracy Segment must be estimated because the existing stations are sparsely distributed. Three estimates of the precipitation distribution for the Tracy Segment were evaluated (table 5). The first estimate of distribution and volume (VanDenburgh and others, 1973) is based on a mean annual precipitation map for the State of Nevada (Hardman, 1965). The second estimate was calculated using a vector-based, 2-km resolution data set for the State of Nevada during the 30-yr period of 1961-90. This data set, hereafter referred to as the 1997 Nevada precipitation map, was derived using the analytical model called Parameter-Elevation Regressions on Independent Slopes Model (PRISM; Daly and others, 1994; Smith and others, 2001). The third estimate is from a local linear regression equation (coefficient of determination, $\mathrm{R}^{2}=0.62$ ) for average annual precipitation measured at 34 stations in northwestern Nevada at altitudes that range from 3,900 to 6,960 ft (Berger and others, 1997, p. 27-32). Precipitation at each station was normalized to 1938-94 average precipitation measured at the airport in Reno to derive the relation:

where

$$
P=(0.00241 \times A)-3.71
$$

$P \quad$ is precipitation in inches, and

A is altitude.

Comparison of measured precipitation to estimates made using each of these methods indicates that the regression approach (Berger and others, 1997) is most accurate (table 3). Average differences between normalized annual precipitation and estimated mean annual precipitation ranged from 0.6 in. less to $3.6 \mathrm{in}$. more than the normalized values. The regression method of estimation (Berger and others, 1997) has the smallest average difference ( 0.2 in. more than measured values) with estimates that range from $2.7 \mathrm{in}$. less to $3.7 \mathrm{in}$. more than the normalized values. Estimates interpolated from the 1997 Nevada precipitation map resulted in the largest average difference (3.6 in. more) and all estimates were greater than normalized values (table 3). Precipitation estimated for individual $2-\mathrm{km}^{2}$ cells that correspond to locations of precipitation gages in table 3 averaged 2.5 in. greater than normalized values and
Table 5. Estimated mean annual precipitation, Tracy Segment Hydrographic Area, west-central Nevada

\begin{tabular}{|c|c|c|c|}
\hline \multicolumn{4}{|c|}{ From Van Denburgh and others, 1973} \\
\hline \multirow{2}{*}{$\begin{array}{c}\text { Altitude zone } \\
\text { (feet above sea } \\
\text { level) }\end{array}$} & \multirow{2}{*}{$\begin{array}{c}\text { Area } \\
\text { (acres) }\end{array}$} & \multicolumn{2}{|c|}{ Annual Precipitation } \\
\hline & & (inches) & (acre-feet) \\
\hline \multicolumn{4}{|c|}{ From Van Denburgh and others, 1973} \\
\hline$>8,000$ & $<10$ & $>20$ & $<10$ \\
\hline $7,000-8,000$ & 1,750 & $15-20$ & 3,000 \\
\hline $6,000-6,999$ & 46,000 & $12-15$ & 51,000 \\
\hline $5,000-5,999$ & 83,600 & $8-12$ & 67,000 \\
\hline $4,045-4,999$ & 56,700 & $5-8$ & 28,000 \\
\hline Total (rounded) & 188,000 & & 150,000 \\
\hline \multicolumn{4}{|c|}{ From 1997 Nevada precipitation map } \\
\hline$>=8,000$ & 3 & 20 & 5 \\
\hline $7,000-7,999$ & 1,990 & $13-20$ & 3,000 \\
\hline $6,000-6,999$ & 47,200 & $11-20$ & 61,000 \\
\hline $5,000-5,999$ & 83,800 & $8-17$ & 87,000 \\
\hline $4,045-4,999$ & 56,700 & $8-13$ & 50,000 \\
\hline Total (rounded) & 190,000 & & 200,000 \\
\hline \multicolumn{4}{|c|}{ From regression of Berger and others, 1997} \\
\hline$>=8,000$ & $<3$ & 16 & $<5$ \\
\hline $7,000-7,999$ & 1,990 & $13-16$ & 2,000 \\
\hline $6,000-6,999$ & 47,200 & $11-13$ & 47,000 \\
\hline $5,000-5,999$ & 83,800 & $8-11$ & 66,000 \\
\hline $4,045-4,999$ & 56,700 & $6-8$ & 33,000 \\
\hline Total (rounded) & 190,000 & & 150,000 \\
\hline
\end{tabular}

ranged from 5.7 in. less to 8.6 in. more than normalized values. Estimates made using the 1965 Nevada precipitation map (Hardman, 1965) had the smallest range in differences when the minimum (2.4 in. more to $3.4 \mathrm{in}$. less) and maximum (5.8 in. more to $0.4 \mathrm{in}$. less) values of each isopleth is considered separately, but uncertainties associated with isopleths defined by ranges of precipitation remain inherent to estimates of precipitation volume.

The estimate of mean annual precipitation made using the 1997 precipitation map is 50,000 acre-ft/yr (33 percent) greater than the other two estimates (table 5). The total area for the estimates made using the digital maps of the study area (U.S. Geological Survey, 2002) are 2,000 acres (less than 2 percent) larger than the amount of area used by VanDenburgh and others (1973). Most (82 percent) of the 50,000 acre-ft difference in precipitation estimated using the 1997 precipitation map came from the altitude zones between 5,000-5,999 $\mathrm{ft}(23,000$ acre-ft) and 4,000-4,999 ft (18,000 acre-ft). Four nearby National Weather Service stations between 4,000$4,500 \mathrm{ft}$ altitude have less than $8 \mathrm{in}$. mean annual precipitation (sites NWS2, NWS3, NWS4, and NWS7; table 3) and two stations above $6,000 \mathrm{ft}$ have less than 16 in. (NWS1 and NWS6; table 3). This suggests that the 1997 map overestimates precipitation for the Tracy Segment, and that the best 
estimate of mean annual precipitation in the Tracy Segment is 150,000 acre-ft.

\section{Evapotranspiration}

ET is the process that transfers moisture from soil and vegetation to the atmosphere making the equivalent amount of precipitation unavailable for ground-water recharge. Therefore, the difference between annual precipitation and annual ET is an estimate of ground-water recharge plus surface-water runoff. ET by phreatophytes, plants that use water from shallow (less than $50 \mathrm{ft}$ ) ground water, can be a component of ground-water discharge. ET measured in the Tracy Segment is for recharge areas where phreatophytes cannot extract water from ground water, but along the Truckee River phreatophytes transpire shallow ground water.

Estimated rates of ET by phreatophytes and associated bare soil in the Great Basin ranged from 0.2 (Harrill and Preissler, 1994, p. H18) to $0.8 \mathrm{ft} / \mathrm{yr}$ (Nichols, 1994, p. 3272) depending on depth to water and canopy density. ET rates from alfalfa and pastures near Fernley, Nevada, ranged from 3 to $4.8 \mathrm{ft} / \mathrm{yr}$ (U.S. Soil Conservation Service, 1992, p. NV68341). Rates of transpiration from a riparian forest of cottonwood and willow in southeastern Arizona were estimated to be $0.016 \mathrm{ft} / \mathrm{d}$ (3.2 ft/yr assuming 200 days of active transpiration) using the heat-pulse velocity technique to measure sap flux (Schaeffer and others, 2000, p. 265).

Daily and monthly ET rates from surface and soil moisture at site 3 (desert shrub) and site 4 (pinion-juniper forest) are shown in figures 6 and 7 and summarized in table 6. Daily values are tabulated in appendix 1. During WY02 (October 2001 through September 2002), ET totaled $11.7 \mathrm{in} / \mathrm{yr}$ at site 3 and $11.5 \mathrm{in} / \mathrm{yr}$ at site 4 . Both sites had minimum rates of 0.001 $\mathrm{in} / \mathrm{d}$, or less, and maximum rates of more than $0.1 \mathrm{in} / \mathrm{d}$. At sites 3 and 4, minimum rates were determined for October 7, 2001, and October 10, 2002, and maximum rates for August 8, 2002, and March 19, 2002, respectively. Seasonal totals were larger during the winter season (October through April) than the summer season (May through September), due to increased availability of moisture and two more winter months. Subtraction of annual ET rates from the three precipitation distributions indicates that non-phreatophytic ET ranges from 140,000 to 177,000 acre-ft/yr.

\section{Surface Water}

Streamflow in the Truckee River and in several agricultural diversions dominate surface water within the Tracy Segment. Streamflow in the Truckee River gains flow in some reaches, and loses flow in others due to the relation between river stage and ground-water levels. Agricultural diversions from the Truckee River are conveyed in unlined canals and ditches that may lose surface water to ground water. The largest agricultural diversion is the Truckee Canal, which collects river water behind Derby Dam and conveys it to agricultural fields near Fernley and to Lahontan Reservoir more than 20 mi away.

Drainage networks tributary to the Truckee River in the Tracy Segment are ephemeral and flow intermittently in response to snowmelt and intense summer thunderstorms. One exception is a short (less than $0.5 \mathrm{mi}$ ) reach that perennially receives ground water from springs and seeps. Most of this surface-water flow infiltrates through the streambed and returns to ground water and the rest is discharged to the atmosphere by ET.

\section{Truckee River and Diversions}

Flow in the Truckee River is regulated by dams constructed at Lake Tahoe, Donner, Independence, and Martis Creek Lakes, and at Prosser Creek, Stampede, and Boca Reservoirs (fig. 1). These dams are used to store water to supplement water supplies during periods of low flow and to mitigate flooding during periods of high flow (Berris, 1996, p. 9). Flow of the Truckee River as it enters the Tracy Segment normally peaks during spring snowmelt and recedes during late summer into fall (Berris and others, 2003, p. 386). Maximum and minimum flows in the Tracy Segment generally are controlled by storage of snowmelt runoff in reservoirs for delivery to agricultural areas during the drier growing season.

Within or near the Tracy Segment, the USGS operates four streamflow-gaging stations on the Truckee River and one on the Truckee Canal (site 16; fig. 2). Information for Truckee River streamflow-gaging stations and active diversions is listed in table 7. The Truckee River is the only perennial inflow, although there are many ephemeral channels tributary to the river. Long-term records of streamflow are available for stations near the upstream (USGS station name and number; Truckee River at Vista, 10350000) and downstream boundaries of the Tracy Segment (Truckee River at Wadsworth, 10351650, and Truckee Canal near Wadsworth, 10351300). The streamflow-gaging station at Vista has operated continuously since October 1958 with intermittent operation since August 1899. The streamflow-gaging station at Wadsworth began operating in May 1965, but was discontinued for seven years starting September 1986 until it was re-established in September 1993. The streamflow-gaging station on the Truckee Canal near Wadsworth has been operating since October 1966 (Berris and others, 2003, p. 386). In addition to the Truckee Canal, there are five active diversions from the river to irrigation canals and three diversions for industrial use (Federal Water Master, written commun., 2003).

The greatest daily mean flow recorded at the Vista streamflow-gaging station was $17,400 \mathrm{ft}^{3} / \mathrm{s}$ on February 1, 1963 and the lowest was $7 \mathrm{ft}^{3} / \mathrm{s}$ on August 26, 1935 (Berris and others, 2003, p. 386). The annual runoff for the Truckee River at the Vista station ranged from 114,600 acre-ft/yr in WY92 to 2,017,000 acre-ft/yr in WY83. The average annual runoff for the period of record from 1899 to 2002 is 597,200 acre$\mathrm{ft} / \mathrm{yr}$ (Berris and others, 2003, p. 386), and from 1998 to 2002 


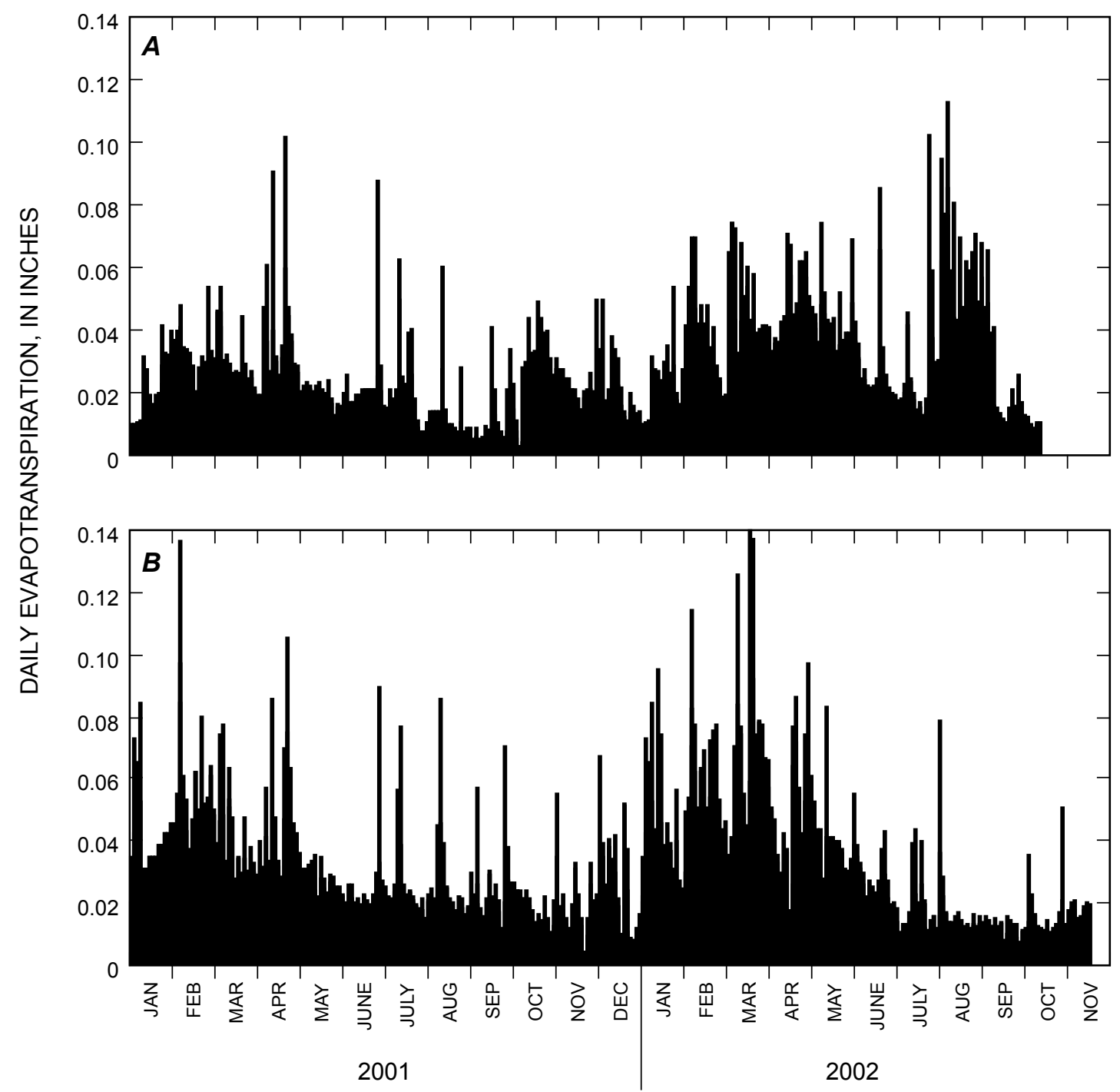

Figure 6. Average daily evapotranspiration measured at the desert shrub site at $5,200 \mathrm{ft}$ altitude, and at the pinion-juniper forest site at 6,100 ft altitude, January 2001-0ctober 2002, Tracy Segment Hydrographic Area, west-central Nevada.

(during this study) annual runoff averaged 614,000 acre-ft/yr (table 7).

The Truckee Canal was completed in 1906 with a flow capacity of about 657,000 acre-ft/yr (Horton, 1997, p. III3). The canal extends about $32 \mathrm{mi}$ east from Derby Dam to Lahontan Reservoir near Fallon and about $12.8 \mathrm{mi}$ of the canal are in the Tracy Segment (fig. 1; Brown and others, 1986, p. 112-115). The canal roughly parallels the Truckee River along a bench to the south, until it bends toward the southeast less than $2 \mathrm{mi}$ west of Fernley (fig. 1). Between Derby Dam and the streamflow-gaging station on the Truckee Canal near Wadsworth, there are five irrigation turnouts for agricultural use in the Wadsworth and Fernley areas and two spillways that are used to return flow to the Truckee River. The canal is unlined except for $1.6 \mathrm{mi}$ through tunnels (Brown and others, 1986, p. 112-113).
VanDenburgh and Arteaga (1985) provided a regression analysis of annual discharge in the Truckee Canal. Seepage loss and estimated average annual seepage loss from the canal for 1968-79 was 1,600 acre-ft/yr/mi of canal. Re-evaluation of these seepage-loss data by linear regression and transformation of annual seepage loss to annual seepage-loss per mile resulted in a mean annual seepage rate of $1,570 \mathrm{acre}-\mathrm{ft} / \mathrm{yr} / \mathrm{mi}$ for 1968-79 (Pohll and others, 2001, p. 24). Daily seepage rates ranging from 0.02 to $1.57 \mathrm{ft} / \mathrm{d}$ and averaging $0.5 \mathrm{ft} / \mathrm{d}$ were estimated using numerical simulation of energy transport and unsaturated fluid flux at six cross sections of the Truckee Canal (Mihevc and others, 2002, p. 43). This corresponds to a mean annual seepage rate of about $1,600 \mathrm{acre}-\mathrm{ft} / \mathrm{yr} / \mathrm{mi}$. Thus, seepage loss estimated by numerical simulation is similar to estimates made by regression analysis with streamflow.

Discharge in the Truckee Canal ranged between 132,000 to 335,000 acre-ft/yr (average 204,000 acre-ft/yr) during the 


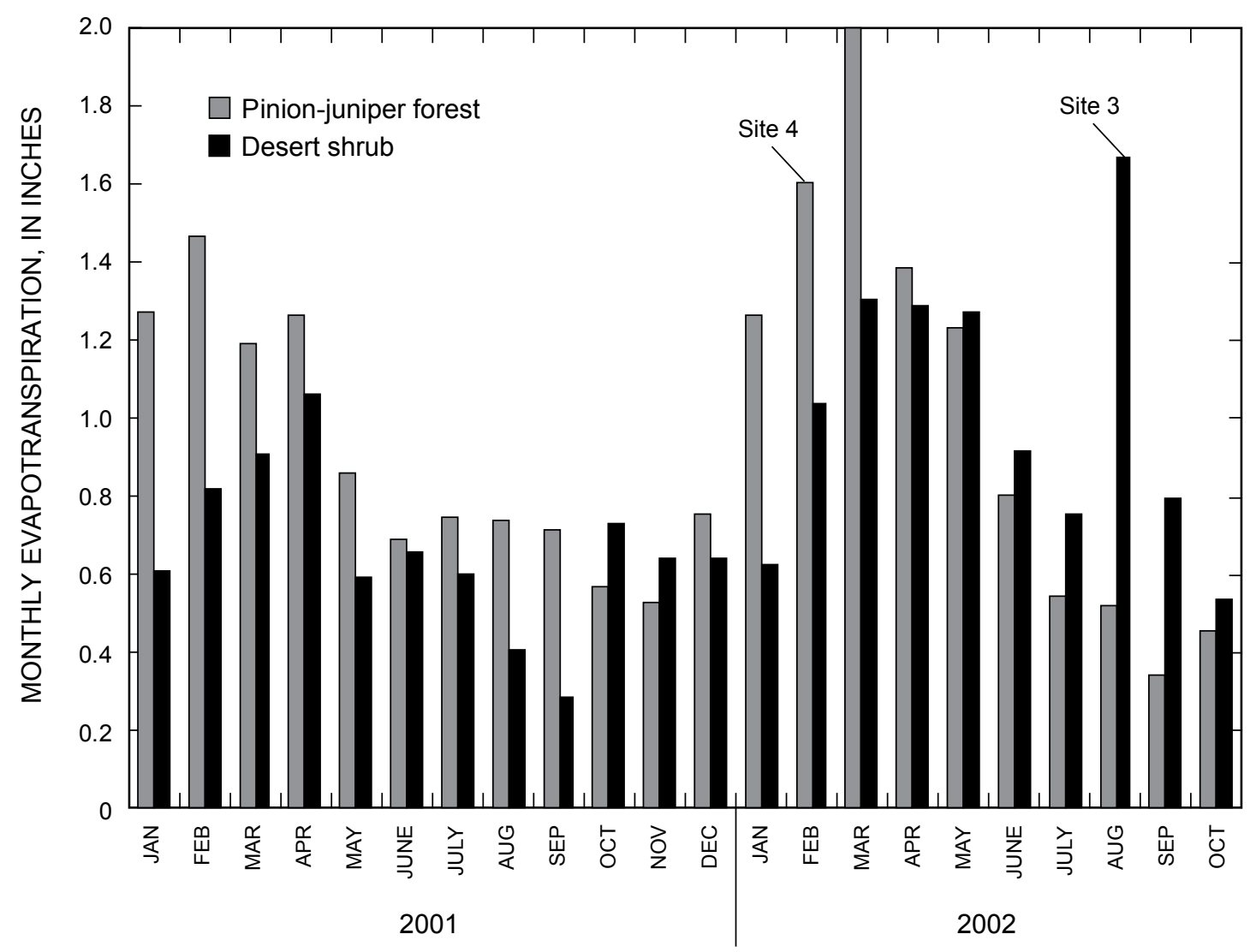

Figure 7. Average monthly evapotranspiration measured at the desert shrub site at 5,200 $\mathrm{ft}$ altitude, and at the pinion-juniper forest site at 6,100 $\mathrm{ft}$ altitude, January 2001-0ctober 2002, Tracy Segment Hydrographic Area, west-central Nevada.

Table 6. Average, maximum, minimum, and seasonal daily evapotranspiration rates, computed using the Bowen-ratio method, January 2001-September 2002, and annual total evapotranspiration for water year 2002, Tracy Segment Hydrographic Area, westcentral Nevada

\begin{tabular}{|c|c|c|c|c|c|c|c|c|}
\hline \multirow[b]{2}{*}{$\begin{array}{l}\text { Site number } \\
\text { (fig. 2) }\end{array}$} & \multicolumn{8}{|c|}{ Evapotranspiration (inches) } \\
\hline & Average daily & $\begin{array}{l}\text { Maximum } \\
\text { daily }\end{array}$ & $\begin{array}{l}\text { Minimum } \\
\text { daily }\end{array}$ & $\begin{array}{l}\text { Winter daily } \\
\text { average }^{1}\end{array}$ & $\begin{array}{c}\text { Summer } \\
\text { daily aver- } \\
\text { age }^{2}\end{array}$ & $\begin{array}{l}\text { Winter } \\
\text { total }{ }^{1}\end{array}$ & $\begin{array}{c}\text { Summer } \\
\text { total }^{2}\end{array}$ & $\begin{array}{r}\text { Annual } \\
\text { total }^{3}\end{array}$ \\
\hline 3 & 0.028 & 0.113 & $<0.001$ & 0.030 & 0.035 & 6.26 & 5.41 & 11.7 \\
\hline 4 & 0.032 & 0.154 & 0.004 & 0.038 & 0.022 & 8.10 & 3.43 & 11.5 \\
\hline
\end{tabular}

${ }^{1}$ October 2001-April 2002

${ }^{2}$ May 2002-September 2002

${ }^{3}$ Water year 2002 (October 2001-September 2002) 
period used by VanDenburgh and Arteaga (1985) and Pohll and others (2001) to estimate seepage loss. During this study (1998-2002), discharge average was 108,000 acre-ft/yr (table 7). Application of their regression equations to the mean annual streamflow reported for Truckee Canal at Wadsworth during 1998-2002 yields an average seepage loss of 830 acre$\mathrm{ft} / \mathrm{yr} / \mathrm{mi}$, or $9,000 \mathrm{acre}-\mathrm{ft} / \mathrm{yr}$ of seepage loss along $11.2 \mathrm{mi}$ of the canal within the Tracy Segment.

\section{Ephemeral Streams}

Mean annual runoff from ungaged subbasins of the Tracy Segment (table 8) was estimated empirically (Moore, 1976) to be about 5,000 acre-ft/yr, with almost half (2,400 acre-ft/yr) attributed to Long Valley Creek. Martin Canyon contributed $1,200 \mathrm{acre}-\mathrm{ft} / \mathrm{yr}$ to the estimated annual mean and unnamed canyon and Pierson Canyon contributed 680 and 230 acre-ft/ $\mathrm{yr}$, respectively. The remaining 60,000 acres of drainage area are at a relatively lower altitude and contributed about 670 acre-ft/yr.

Analysis of a digital elevation model (U.S. Geological Survey, 2002) of the area indicates that about $390 \mathrm{mi}$ of channels are within the Tracy Segment. About 68 percent of the area is drained by four drainages (Long Valley Creek, Martin Canyon, an unnamed canyon in the Pah Rah Range, and Pier- son Canyon; fig. 1). These basins include more than $70 \mathrm{mi}^{2}$ above $6,000 \mathrm{ft}$. The remaining area ( 32 percent) includes only $5 \mathrm{mi}^{2}$ above $6,000 \mathrm{ft}$ and more than 20 individual channels are in this area. Long Valley Creek (fig. 1) is the largest drainage basin entirely within the Tracy Segment and has had a creststage gage (CSG) operating intermittently by the USGS since 1956 (station number 10350100; WY56, 67-78, 86, 95-02). CSGs are used to record peak stage of ephemeral runoff events. The location of the gage is downstream from about 82 $\mathrm{mi}^{2}$ of ephemeral drainage area (Berris and others, 2003, p. 421 ) and less than one mile upstream of its confluence with the Truckee River. Total drainage area is about $99 \mathrm{mi}^{2}$.

Peak discharge estimated for the CSG on Long Valley Creek is listed in table 9. The largest recorded peak was 5,400 $\mathrm{ft}^{3} / \mathrm{s}$ on February 19, 1986, and resulted from more than 6 in. of precipitation over the prior 10-day period. The smallest peak was $0.05 \mathrm{ft}^{3} / \mathrm{s}$ on May 1, 2002, and estimated to be less than $0.1 \mathrm{ft}^{3} / \mathrm{s}$ on March 18, 2002. On August 2, 2002, a thunderstorm generated flow in ephemeral channels of Martin Canyon that had a peak discharge of about $40 \mathrm{ft}^{3} / \mathrm{s}$, estimated using the slope-area method (Dalrymple and Benson, 1967). Streamflow was not recorded at the Long Valley Creek CSG during this storm.

Table 7. Information for surface-water gaging stations and diversions in and near Tracy Segment Hydrographic Area, westcentral Nevada

[Symbol: —, site number not established]

\begin{tabular}{|c|c|c|c|c|c|}
\hline $\begin{array}{l}\text { Site } \\
\text { number } \\
\text { (fig. 2) }\end{array}$ & $\begin{array}{l}\text { Station } \\
\text { number }\end{array}$ & $\begin{array}{l}\text { U.S. Geological Survey } \\
\text { station name }\end{array}$ & Period of record & $\begin{array}{c}\text { Average } \\
\text { annual flow } \\
\text { for period of } \\
\text { record } \\
\text { (acre-feet/ } \\
\text { year) }\end{array}$ & $\begin{array}{c}\text { Average flow } \\
\text { for water years } \\
\text { 1998-2002 } \\
\text { (acre-feet/year) }\end{array}$ \\
\hline 13 & 10350000 & Truckee River at Vista & $\begin{array}{l}\text { Aug. } 1899 \text { to Dec. 1907, Jan. } 1932 \\
\text { to Dec. 1954, Oct. 1958-Sept. } \\
2002\end{array}$ & ${ }^{2} 597,200$ & 614,000 \\
\hline - & 10350320 & McCarran Ditch near Patrick & 1978-2002, Apr.-Sept. & ${ }^{3} 2,000$ & ${ }^{3} 1,000$ \\
\hline 14 & 10350340 & Truckee River near Tracy & June 1998 to Sept. 2002 & ${ }^{2} 625,100$ & 625,000 \\
\hline - & - & Industrial use & Not gaged & 1,400 & 1,400 \\
\hline 15 & 10351600 & Truckee River below Derby Dam & $\begin{array}{l}\text { Jan. } 1918 \text { to July } 1958 \text {, Oct. } 1958 \\
\text { to Sept. } 2002\end{array}$ & ${ }^{2} 299,100$ & 454,400 \\
\hline - & 10351635 & Herman Ditch near Wadsworth & 1978-2002, Apr.-Sept. & 33,200 & ${ }^{3} 2,700$ \\
\hline - & 10351638 & Gregory Ditch near Wadsworth & 1978-2002, Apr.-Sept. & ${ }^{3} 1,200$ & ${ }^{3} 600$ \\
\hline 17 & 10351650 & Truckee River at Wadsworth & May 1965 to Sept. 2002 & ${ }^{2} 553,000$ & 507,500 \\
\hline
\end{tabular}

${ }^{1}$ Eight-digit number is used to identify each streamflow-gaging station. For example, station number 10350000 consists of two-digit part number (10) followed by six-digit downstream-order number (350000). Part number refers to drainage area or group of areas that is generally regional in extent. Part 10 is for drainage areas in the Great Basin. Downstream order number is assigned according to geographic location of station in drainage network; larger number stations are downstream from smaller number stations. Locations are shown on figure 2.

${ }^{2}$ Berris and others, 2003, p. 386, 387, 395, 397, 400.

${ }^{3}$ Federal Water Master's records for April through September. 


\section{Gains and Losses of the Truckee River}

In addition to ET, diversions, and inflows from ephemeral tributaries, the amount of streamflow in the Truckee River was affected along its reach in the Tracy Segment by movement of water into and out of rocks and alluvium that comprise the streambed and alluvial aquifers. Measuring the movement was difficult because the amount of ground-water gain or loss may be equal to the uncertainty associated with even the most accurate streamflow measurement. For example, an excellent streamflow measurement has an uncertainty of 2 percent. For a typical discharge in the Truckee River of $500 \mathrm{ft}^{3} / \mathrm{s}$, this would be $\pm 10 \mathrm{ft}^{3} / \mathrm{s}$, or 7,200 acre-ft/yr. However, such uncertainty, if randomly distributed without bias, should be reduced with multiple measurements and long-term record.

Comparison of average annual streamflow in the Truckee River entering and leaving the Tracy Segment (table 7) indicated that the Truckee River gained about 11,000 acre-ft/yr (WY1998-2002). Estimated gains or losses of streamflow between gaging stations indicated a gain of about 15,000 acre-ft/yr between Vista and near Tracy, a loss of about 61,000 acre-ft/yr between Tracy and below Derby Dam, and a gain of 58,000 acre-ft/yr between Derby Dam and Wadsworth.

An ungaged quantity of water diverted from the river into the Truckee Canal is routinely returned to the Truckee River from spillways and irrigation returns downstream of the streamflow-gaging station below Derby Dam. Also, during this period, part of the estimated 9,300 acre-ft/yr of seepage loss from the Truckee Canal probably returned to Truckee River as ground water. An additional 3,000 acre- $\mathrm{ft} / \mathrm{yr}$ of ground water was estimated as discharge to the Truckee River from the Fernley Area HA (VanDenburgh and Arteaga, 1985, p. 11).

Differences in flow were computed from seven sets of instantaneous discharge measurements made at the stream-

Table 8. Estimated area and mean annual runoff from ephemeral streams, Tracy Segment Hydrographic Area and selected subbasins (estimates are rounded), west-central Nevada

\begin{tabular}{|c|c|c|}
\hline $\begin{array}{l}\text { Mean precipitation } \\
\text { that contributes to } \\
\text { runoff } \\
\text { (feet) }\end{array}$ & $\begin{array}{c}\text { Drainage area } \\
\text { (acres) }\end{array}$ & $\begin{array}{c}\text { Mean annual } \\
\text { runoff } \\
\text { (acre-feet per } \\
\text { year) }\end{array}$ \\
\hline \multicolumn{3}{|c|}{ Tracy Segment Hydrographic Area } \\
\hline 0.026 & 189,700 & 5,000 \\
\hline \multicolumn{3}{|c|}{ Long Valley Creek } \\
\hline .038 & 63,200 & 2,400 \\
\hline \multicolumn{3}{|c|}{ Martin Canyon } \\
\hline .030 & 40,500 & 1,200 \\
\hline \multicolumn{3}{|c|}{ Unnamed canyon near Dry Lakes } \\
\hline .039 & 17,600 & 680 \\
\hline \multicolumn{3}{|c|}{ Pierson Canyon } \\
\hline .027 & 8,400 & 230 \\
\hline \multicolumn{3}{|c|}{ Remaining drainage areas } \\
\hline .011 & 60,000 & 670 \\
\hline
\end{tabular}

flow-gaging stations on the Truckee River at Vista and at Wadsworth, and on the Truckee Canal near Wadsworth within a 1 to 2-day period, during October-April for 1969-73 and are listed in table 10 . These differences ranged from a loss of $32 \mathrm{ft}^{3} / \mathrm{s}$ to a gain of $91 \mathrm{ft}^{3} / \mathrm{s}$ with an average gain of $23 \mathrm{ft}^{3} / \mathrm{s}$ $(17,000 \mathrm{acre}-\mathrm{ft} / \mathrm{yr})$. Both losses were measured in early October when diversions for agricultural irrigation and riparian ET still may have been occurring.

Seepage investigations consist of a series of instantaneous discharge measurements scheduled to be made within about a 2-day interval at several locations along a river, in order to evaluate gains and losses of flow. Seepage measurements were made six times between 1971-94 and are summarized in table 11. Total flows were less than $200 \mathrm{ft}^{3} / \mathrm{s}$, which reduces uncertainty of the discharge measurement to about 10 $\mathrm{ft}^{3} / \mathrm{s}$. Discharge measurements are accurate to within 5 percent and gains or losses that are smaller may be apparent rather than real.

Four of the six seepage investigations in the Tracy Segment showed small gains (table 11); however, only three of the six seepage investigations included the entire reach of the river within the area. Maximum gain in flow was $11.3 \mathrm{ft}^{3} / \mathrm{s} / \mathrm{mi}$ between measurements made at Lockwood ( 2 mi downstream of Vista) and Mustang Bridge No. 1 (4 mi downstream of Vista) and a maximum loss in flow was $11.2 \mathrm{ft}^{3} / \mathrm{s} / \mathrm{mi}$ between the Vista streamflow-gaging station and Lockwood. Both maximums were measured in October 1991. The seepage measurement data indicate that ground water interacts with the Truckee River along much of its length within the Tracy Segment.

\section{Ground-Water Distribution and Movement}

Ground water within the Tracy Segment is found in voids between grains of basin-fill deposits and in joints, fractures, and rubble zones of consolidated rocks. Ground water is recharged from precipitation, and infiltration below the Truckee River channel, irrigation canals and ditches, and power station cooling ponds. Ground water recharged by precipitation in the mountain blocks and thicker alluvial-fan deposits at intermediate altitudes (less than 6,000 ft) flows toward the valley floor. Most precipitation is consumed by ET and returned to the atmosphere by ET and some becomes ephemeral runoff, depending on the intensity of the precipitation or rate of snowmelt. Ephemeral runoff may contribute to ground-water recharge, although water is subject to ET until it infiltrates beneath the effective root depth (Izbicki, 2002). Due to the thick (more than $100 \mathrm{ft}$ ), heterogeneous nature of alluvial fans, infiltrated streamflow may reside within the unsaturated zone for centuries (Izbicki and others, 1998, p. 87). However, periodic recharge from ephemeral streamflow will converge in unsaturated deposits to support a relatively steady flux into the water table.

Basin-fill deposits of the Truckee River flood plain in the Tracy Segment continue across the hydrographic bound- 
Table 9. Peak discharge at Long Valley Creek crest-stage gage (10350100) and precipitation recorded at National Weather Service station near Virginia City, Tracy Segment Hydrographic Area, west-central Nevada

\begin{tabular}{|c|c|c|c|c|}
\hline \multirow[b]{2}{*}{$\begin{array}{c}\text { Date of } \\
\text { measurement }\end{array}$} & \multirow[b]{2}{*}{$\begin{array}{l}\text { Peak discharge, } \\
\text { (in cubic feet } \\
\text { per second) }\end{array}$} & \multicolumn{3}{|c|}{ Precipitation (inches) } \\
\hline & & 24 hour & $\begin{array}{c}\text { 110-Day } \\
\text { cumulative }\end{array}$ & $\begin{array}{c}\text { 220-Day } \\
\text { cumulative }\end{array}$ \\
\hline Dec. 23,1955 & 2,500 & 1.90 & 3.38 & 3.74 \\
\hline Jan. 29, 1967 & 232 & 0.50 & 2.25 & 2.27 \\
\hline Mar. 16, 1967 & 1,430 & 1.24 & 2.10 & 2.30 \\
\hline Jan. 2, 1969 & 2,560 & 0.0 & 0.72 & 1.46 \\
\hline Jan. 30, 1974 & 105 & 0.0 & 0.15 & 1.41 \\
\hline Aug. 11, 1976 & 17 & 0.0 & 0.14 & 1.19 \\
\hline Feb. 19, 1986 & 5,400 & 1.78 & 6.88 & 7.41 \\
\hline Mar. 10, 1995 & 2,750 & 0.80 & 1.97 & 1.97 \\
\hline Feb. 4, 1996 & 370 & 0.18 & 1.97 & 4.20 \\
\hline Jan. 2, 1997 & 1,560 & 0.98 & 2.02 & 5.24 \\
\hline Jan. 25, 1997 & 700 & 0.68 & 2.41 & 2.54 \\
\hline Mar. 24, 1998 & 318 & 0.61 & 2.27 & 2.27 \\
\hline Feb. 19, 1999 & e2 & 0 & 0 & 2.95 \\
\hline June 30, 2000 & $\mathrm{e}<50$ & 0 & 0.08 & 0.08 \\
\hline Mar. 9, 2001 & $\mathrm{e}^{\mathrm{e}}<1$ & 0 & 0.07 & 0.54 \\
\hline Mar. 18, 2002 & ${ }^{\mathrm{e}}<0.1$ & 0 & 0.29 & 1.17 \\
\hline May 1, 2002 & 0.05 & 0 & 0.22 & 0.72 \\
\hline \multicolumn{5}{|c|}{$\begin{array}{l}{ }^{1} 10 \text {-day cumulative precipitation is sum of precipitation reported for the date of measurement plus the nine days } \\
\text { prior to the date of measurement. }\end{array}$} \\
\hline
\end{tabular}

Table 10. Gain or loss of Truckee River streamflow in Tracy Segment Hydrographic Area, west-central Nevada, based on the difference between discharge measured by the U.S. Geological Survey at the Truckee River gaging station at Vista and the sum of discharge measured at the Truckee River gaging station at Wadsworth and at the Truckee Canal near Wadsworth

\begin{tabular}{lcc} 
Date & \multicolumn{2}{c}{ Difference in flow } \\
\cline { 2 - 3 } & $\begin{array}{c}\text { (cubic feet per } \\
\text { second) }\end{array}$ & $\begin{array}{c}\text { (acre-feet } \\
\text { per year) }\end{array}$ \\
\hline $12-15-69$ & 25 gain & 18,000 gain \\
$10-5-70$ & 22 loss & 16,000 loss \\
${ }^{1} 1-4-73$ & 91 gain & 66,000 gain \\
${ }^{1} 3-6-73$ & 29 gain & 21,000 gain \\
${ }^{1} 10-3-78$ & 32 loss & 23,000 loss \\
${ }^{1} 12-6-84$ & 24 gain & 17,000 gain \\
$11-30-93$ & 46 gain & 46,000 gain \\
Average & 23 gain & 18,000 gain \\
\hline
\end{tabular}

${ }^{1}$ Measurement at Vista gaging station made 1 day prior to other measurements ary from the Truckee Meadows HA to the west side and into the Dodge Flat and Fernley Area HAs to the east. Inflow to the Tracy Segment from the Truckee Meadows HA has been estimated as minor due to the limited thickness of the basinfill aquifer beneath the western boundary (VanDenburgh and others, 1973, p. 44). Inflow to the Tracy Segment from the Fernley Area HA was estimated to be more than 3,000 acre$\mathrm{ft} / \mathrm{yr}$ primarily due to irrigation and seepage loss from the Truckee Canal. Outflow to the Dodge Flat HA was estimated to be 1,200 acre-ft/yr (VanDenburgh and Arteaga, 1985, p. 11).

Average water-level altitudes measured during 20002002 are shown in figure 8 . Also shown in figure 8 are water levels for boreholes that were drilled to a depth of at least 400 $\mathrm{ft}$ below land surface but were abandoned because they were unable to produce at least $10 \mathrm{gal} / \mathrm{min}$ (sites 54-61; Consulting Services Associates, Inc., 1997). The highest water-level altitudes (more than 5,500 ft) are in the Virginia Range in the southwestern portion of the Tracy Segment near the intermittent headwaters of Long Valley Canyon and Lousetown Creeks. Wells 23, 47, and 48 (fig. 2) are completed in permeable bedrock near the southeastern and western boundaries of the Tracy Segment and have water-level altitudes higher than 
Table 11. Summary of streamflow measurements and gains to and losses from Truckee River, Tracy Segment Hydrographic Area, west-central Nevada, 1971-1994

[All values are in cubic feet per second. Symbol: —, no data collected. Source of data: 1971, U.S. Geological Survey, 1972, p. 174; 1991, Hess and others, 1993, p. 400-402; 1993, Clary and others, 1995, p. 557; 1994, Bauer and others, 1996, p. 535]

\begin{tabular}{|c|c|c|c|c|c|c|c|c|c|c|c|c|c|}
\hline \multirow{3}{*}{$\begin{array}{l}\text { Site } \\
\text { num- } \\
\text { ber }\end{array}$} & \multirow{3}{*}{$\begin{array}{l}\text { River } \\
\text { mile }\end{array}$} & \multirow{2}{*}{\multicolumn{2}{|c|}{$\begin{array}{c}1971 \\
\text { September } 2 \\
\end{array}$}} & \multirow{2}{*}{\multicolumn{2}{|c|}{$\begin{array}{c}1991 \\
\text { October 30-31 }\end{array}$}} & \multirow{2}{*}{\multicolumn{2}{|c|}{$\begin{array}{c}1992 \\
\text { September } 8 \\
\end{array}$}} & \multirow{2}{*}{\multicolumn{2}{|c|}{$\begin{array}{c}1993 \\
\text { November 29-30 }\end{array}$}} & \multicolumn{4}{|c|}{1994} \\
\hline & & & & & & & & & & \multicolumn{2}{|c|}{ January 19-20 } & \multicolumn{2}{|c|}{ November 1} \\
\hline & & Flow & $\begin{array}{l}\text { Gain } \\
\text { or } \\
\text { loss(-) }\end{array}$ & Flow & $\begin{array}{c}\text { Gain } \\
\text { or } \\
\text { loss(-) }\end{array}$ & Flow & $\begin{array}{c}\text { Gain } \\
\text { or } \\
\text { loss(-) }\end{array}$ & Flow & $\begin{array}{l}\text { Gain } \\
\text { or } \\
\text { loss(-) }\end{array}$ & Flow & $\begin{array}{c}\text { Gain } \\
\text { or } \\
\text { loss(-) }\end{array}$ & Flow & $\begin{array}{c}\text { Gain } \\
\text { or } \\
\text { loss(-) }\end{array}$ \\
\hline${ }^{a} 1$ & 0 & - & - & 124.0 & - & 56.7 & - & 124 & - & - & - & - & - \\
\hline${ }^{b} 2$ & 2.2 & - & - & 99.4 & -24.6 & 55.2 & -1.5 & 135 & 11 & - & - & - & - \\
\hline$c 3$ & 4.0 & - & - & $119.8 \mathrm{~b}$ & 20.4 & 56.9 & 1.7 & - & - & - & - & - & - \\
\hline${ }^{d} 4$ & 7.3 & - & - & 102.0 & -17.8 & 65.6 & 8.7 & 164 & 29 & - & - & - & - \\
\hline${ }^{e} 5$ & 11.6 & - & - & 96.5 & -5.5 & 41.4 & -24.2 & 165 & 1 & - & - & - & - \\
\hline${ }^{f} 6$ & 13.6 & - & - & 102.0 & 5.5 & 42.4 & 1.0 & - & - & - & - & - & - \\
\hline 87 & 17.4 & - & - & 102.0 & 0 & 37.9 & -4.5 & - & - & 151 & - & - & - \\
\hline${ }^{h} 8$ & 17.7 & ${ }^{m} 20$ & - & 8.17 & -6.8 & 8.8 & -6.1 & 6.3 & -2.7 & 3.4 & -2.6 & 0.68 & - \\
\hline${ }^{i} 9$ & - & - & - & ${ }^{m} 87$ & - & ${ }^{m} 23$ & - & 156 & - & 145 & - & ${ }^{m} 52$ & - \\
\hline${ }^{j} 10$ & 22.3 & - & - & 11.1 & - & 10.0 & - & 12 & - & 6.7 & 3.3 & 3.5 & 2.8 \\
\hline${ }^{k} 11$ & 28.5 & 52 & ${ }^{n} 32$ & 10.7 & -0.4 & 7.8 & -2.2 & - & - & - & - & - & - \\
\hline${ }^{l} 12$ & 29.1 & - & - & - & - & - & - & 14 & 2.0 & 7.0 & 0.3 & 5.7 & 0.9 \\
\hline $\begin{array}{l}\text { Net ga } \\
\text { loss } \\
\text { (rou }\end{array}$ & $\begin{array}{l}\text { or } \\
\text { er mile } \\
\text { ded) }\end{array}$ & & +3.0 & & -1.0 & & -1.0 & & +1.4 & & +0.1 & & +0.3 \\
\hline
\end{tabular}

aStation number 10350000 , Truckee River at Vista, Nev. latitude $39^{\circ} 31^{\prime} 05^{\prime \prime}$, longitude $119^{\circ} 40^{\prime} 58^{\prime \prime}$, in northwest quarter of northeast quarter of section 13 , Township 19 North, Range 20 East.

'Station number10350050, Truckee River at Lockwood, Nev. latitude $39^{\circ} 30^{\prime} 36^{\prime \prime}$, longitude $11^{\circ} 38^{\prime} 52^{\prime \prime}$, in southeast quarter of southeast quarter of section 17, Township 19 North, Range 21 East.

'Station number10350153, Truckee River at Mustang Bridge No. 1, latitude 39³0'48”, longitude $119^{\circ} 37^{\prime}$ '08', in northeast quarter of southwest quarter of section 15, Township 19 North, Range 21 East.

‘Station number10350200, Truckee River at Patrick, Nev. latitude 39³2’49”, longitude $119^{\circ} 34^{\prime} 59^{\prime}$ ', in northwest quarter of northwest quarter of section 1, Township 19 North, Range 21 East.

'Station number10350400, Truckee River below Tracy, Nev. latitude 39³3'52", longitude $119^{\circ} 31^{\prime} 02^{\prime}$, in northwest quarter of northeast quarter of section 33, Township 20 North, Range 22 East.

'Station number10350500, Truckee River at Clark, Nev. latitude 39³3'56”, longitude $119^{\circ} 29^{\prime} 08^{\prime \prime}$, in southeast quarter of southwest quarter of section 26 , Township 20 North, Range 22 East.

¿Station number 393520119270700, Truckee River above Derby Dam near Wadsworth, Nev. latitude 39³5'20”, longitude 119²7’07”, in southeast quarter of northeast quarter of section 24, Township 20 North, Range 22 East.

"Station number10351600, Truckee River below Derby Dam, near Wadsworth, Nev. latitude $39^{\circ} 35^{\prime} 05^{\prime \prime}$, longitude $119^{\circ} 26^{\prime} 25^{\prime \prime}$, in northwest quarter of southeast quarter of section 19, Township 20 North, Range 23 East.

'Station number10351010, Truckee Canal below Derby Dam near Wadsworth, Nev. latitude 39³5'08”, longitude $119^{\circ} 26^{\prime} 53^{\prime \prime}$, in southeast quarter of southeast quarter of section 19, Township 20 North, Range 23 East.

'Station number10351619, Truckee River at Painted Rock Bridge near Wadsworth, Nev. latitude $39^{\circ} 35^{\prime} 28^{\prime \prime}$, longitude $119^{\circ} 21^{\prime} 59^{\prime}$, in northwest quarter of northeast quarter of section 23, Township 20 North, Range 23 East.

'Station number10351648, Truckee River at Old U.S. 40 Bridge at Wadsworth, Nev. latitude 39॰37'55”, longitude $119^{\circ} 16^{\prime} 54^{\prime \prime}$, in southwest quarter of northwest quarter of section 3, Township 20 North, Range 24 East.

'Station number10351650, Truckee River at Wadsworth, Nev. latitude $39^{\circ} 37^{\prime} 56^{\prime}$, longitude $119^{\circ} 16^{\prime} 56^{\prime}$ ', in southwest quarter of northwest quarter of section 3, Township 20 North, Range 24 East.

mean daily discharge.

"Includes estimated $1 \mathrm{ft}^{3} / \mathrm{s}$ that bypasses section in two irrigation ditches. 
$5,000 \mathrm{ft}$. Water levels measured in two of these wells (47 and 48) during this study show declines due to drought conditions during data collection (fig. 9). Site 47 is pumped intermittently to water stock and "wild" (feral) horses.

Water levels measured in wells completed in permeable bedrock beneath thick unsaturated zones (sites 33-35, 36, 41, and 43-45; fig. 2) show less response to the drought (fig. 10) than sites 47 and 48 (fig. 9). Depth to water in all of these wells is greater than $100 \mathrm{ft}$ below land surface, and as much as $472 \mathrm{ft}$ at site 46 . Water levels at sites 40 through 45 are close to the altitude (about 4,220 ft) of the closest reach of the Truckee River (almost $1 \mathrm{mi}$ to $1.8 \mathrm{mi}$ from sites 40 and 45 , respectively), indicating a potential for river water to infiltrate through the riverbed, recharging ground water that flows in a southeasterly direction. The flat hydraulic gradient (fig. 8) also is evidence of some permeable bedrock in this vicinity.

Water levels measured in wells near the Truckee River (sites 19, 20, 22, 24-28, 30, 31, 37, 38, 39, and 49-53; figs. 2 and 8 ) indicate a horizontal hydraulic-head gradient that roughly parallels the gradient of the river. The mean stage of the Truckee River is about $330 \mathrm{ft}$ higher at the streamflowgaging station at Vista than at the streamflow-gaging station at Wadsworth, which corresponds to an average hydraulic gradient of $0.002 \mathrm{ft} / \mathrm{ft}$. The water-level altitude at site 19 is $325 \mathrm{ft}$ higher than the water level at site 53 and the average hydraulic gradient also is $0.002 \mathrm{ft} / \mathrm{ft}$. However, relations between ground-water levels and nearby river stage vary locally along discrete reaches of the Truckee River in the Tracy Segment.

Water-level altitudes at site 19 generally were $16 \mathrm{ft}$ higher than the river stage at the nearby USGS streamflowgaging station at Vista, but water-level altitudes at site 20 averaged about the same altitude as river stage. Sites 19 and 20 are nested in a single 161-ft deep borehole that was drilled through more than $110 \mathrm{ft}$ of interbedded clay, sand, and gravel, and below that into about $50 \mathrm{ft}$ of basalt. Site 19 was screened and gravel packed in the basalt from $125-161 \mathrm{ft}$ and site 20 was screened and gravel packed from 13 to $28 \mathrm{ft}$ below land surface. Site 21 is a community supply well near Lockwood and the water level reported at the time of well construction was about $10 \mathrm{ft}$ above the altitude of the riverbed at the Truckee River at the mouth of Long Valley Creek (4,316 $\mathrm{ft}$; Brown and others, 1986, p. 108). Water-level altitudes for these three wells indicate an upward hydraulic gradient between deep, permeable bedrock and shallow alluvium, indicating a potential for ground-water discharge into the Truckee River. This gradient supports previously discussed gains in Truckee River streamflow between streamflow-gaging stations at sites 13 and 14 .

Sites 22, 24, 25, and 26 are near a reach of the Truckee River that has a reported streambed altitude of $4,305 \mathrm{ft}$ (Brown and others 1986, p. 109), which is 24 to $47 \mathrm{ft}$ higher than water-level altitudes at these four sites. Average water-level altitudes at sites 27 and 28 are about $9 \mathrm{ft}$ and $39 \mathrm{ft}$ higher than streambed altitudes reported for the nearby river reaches (4,259 and 4,247 ft, respectively; Brown and others, 1986, p. 110-111), but average water-level altitudes at sites 29 and 30 are 1 to $2 \mathrm{ft}$ lower than the Truckee River riverbed (Brown and others, 1986, p. 110). Average water-level altitude at site 38 is about $5 \mathrm{ft}$ higher than the reported riverbed altitude $(4,230$ $\mathrm{ft}$; Brown and others, 1986, p. 112). Site 49 is a domestic well with water-level altitudes that ranged from 5 to more than $80 \mathrm{ft}$ lower than the reported riverbed altitude $(4,085 \mathrm{ft}$; Brown and others. 1986, p. 117); however, most of the water levels were measured when the well had been recently pumped. Average water-level altitudes at sites 50 and 51 are about equal to the reported riverbed altitude (4,075 ft; Brown and others, 1986, p. 117), whereas the average water-level altitude at site 52 is about $16 \mathrm{ft}$ higher. The average water-level altitude at site 53 is about $4 \mathrm{ft}$ higher than the reported streambed altitude $(4,055$ $\mathrm{ft}$; Brown and others, 1986, p. 118).

Ground-water level altitudes and Truckee River stage at Vista (fig. 11A) show that the ground water in the shallow alluvial aquifer at site 20 is controlled by Truckee River stage, whereas the river does not significantly influence the deep fractured bedrock aquifer at site 19 due to more than $100 \mathrm{ft}$ of interbedded clay that overlies the fractured-rock aquifer. When river stage increased about $2.3 \mathrm{ft}$ between March 23 and April 16, 2002, water levels at site 20 increased about $1.6 \mathrm{ft}$, whereas the response at site 19 was minimal. River stage and the water level at site 20 both receded to near initial (March 23,2002 ) altitudes by July 2, 2002, and site 19 remained relatively unaffected.

Water-level data for sites 30 and 31, and Truckee River stage near Tracy (site 14; fig. 11B) show that water levels in the two wells were nearly identical. Water levels in the shallow alluvial well (site 30 ) were less than $0.5 \mathrm{ft}$ higher than levels in the deeper fractured bedrock well (site 31). Altitude of the river stage was about $3 \mathrm{ft}$ higher than water-level altitudes indicating a hydraulic gradient away from the river and downward through the alluvial aquifer into fractured bedrock. Site 31 was affected by pumpage during April and May 2002 (fig. 11B). The first drawdown period was in response to a 60-hr pumped-aquifer test of a production well pumping from bedrock located about $0.25 \mathrm{mi}$ southeast of the river. Analysis of pumpage and drawdown data (Brown and Caldwell, written commun., 2002) indicate that drawdown at site 31 was affected by leakage from the Truckee River. Transmissivity and storage coefficient estimated using Theis solutions and image well theory that simulates an infinite source of water, were $400 \mathrm{ft}^{2} / \mathrm{d}$ and 0.0003 , respectively.

Water-level altitudes reported in 1993 for 12 monitoring wells in the vicinity of the Tracy Power Station (fig. 1), less than $0.5 \mathrm{mi}$ from the Truckee River, ranged from 4,249.91 ft between the Truckee River and a cooling pond, to 4,235.44 ft southeast of the cooling pond (Sierra Pacific Power Company and Ebasco Environmental, 1993). The cooling pond was reported to leak about 560 acre-ft/yr, which forms a groundwater mound beneath the pond and resulted in hydraulic gradients of about $0.007 \mathrm{ft} / \mathrm{ft}$ near the pond to $0.001 \mathrm{ft} / \mathrm{ft}$ about $0.5 \mathrm{mi}$ southeast of the pond. About $200 \mathrm{acre}-\mathrm{ft} / \mathrm{yr}$ was estimated to discharge as ground-water seepage to the Truckee River and $360 \mathrm{acre}-\mathrm{ft} / \mathrm{yr}$ moved into aquifers to the southeast. 


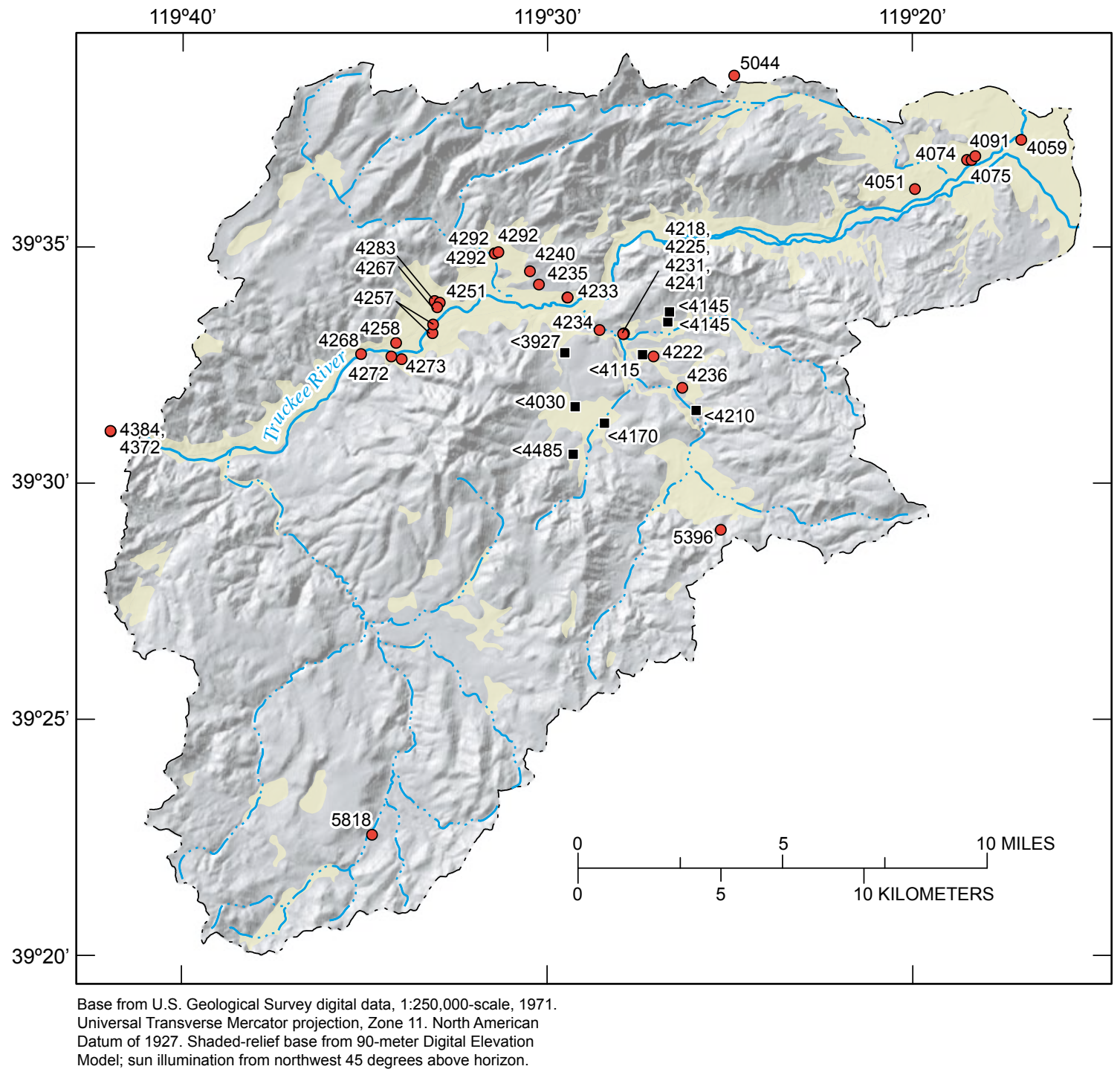

\section{EXPLANATION}

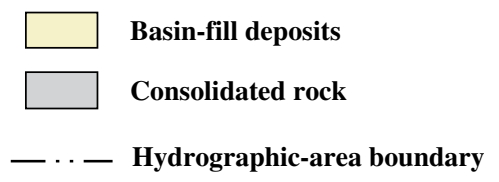
Ground-water site-Number is elevation 4222 ○ Well site- Measured on well run $<4115$ a Dry borehole

Figure 8. Average water-level altitude for wells, 2000-2002, in and near the Tracy Segment Hydrographic Area, westcentral Nevada. 


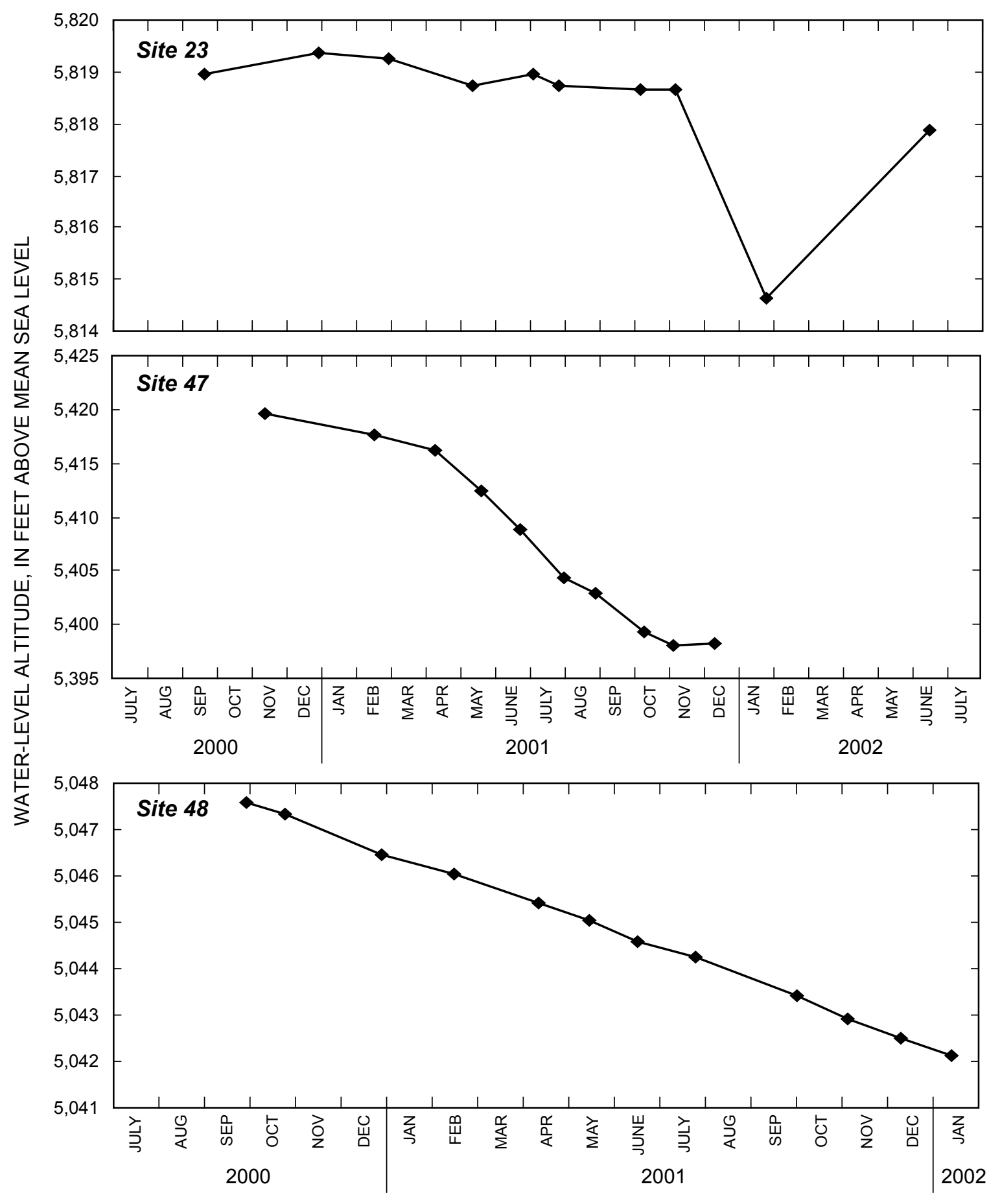

Figure 9. Measured water-level fluctuations in selected wells completed in consolidated-rock aquifers in the mountain block, 2000-2002, Tracy Segment Hydrographic Area, west-central Nevada. 


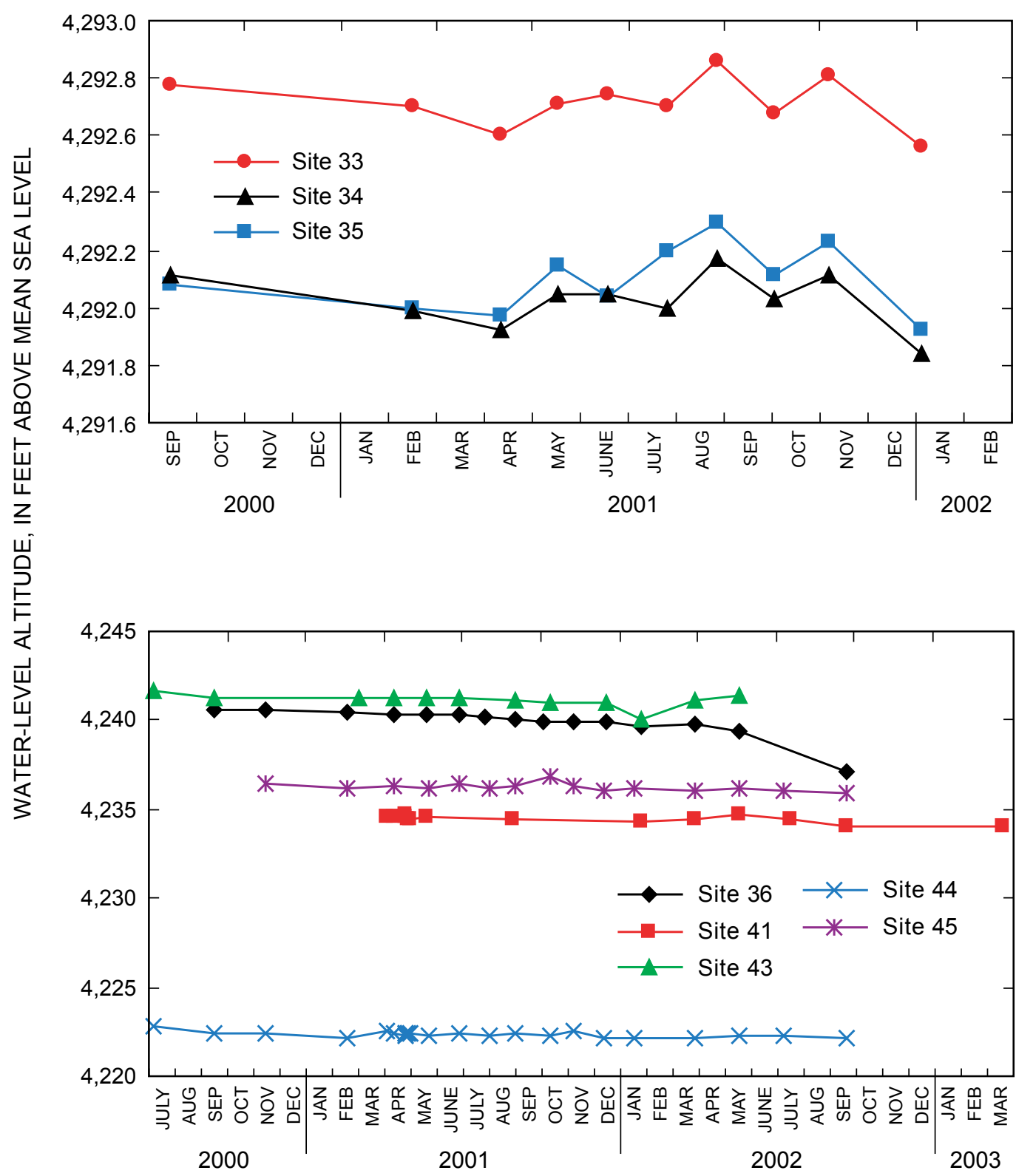

Figure 10. Measured water-level fluctuations in selected wells completed in consolidated-rock aquifers beneath alluvial-fan deposits, 2000-2002, Tracy Segment Hydrographic Area, west-central Nevada. 
Ground-water levels more than one mile south of the river in the uplands are at altitudes higher than these reported water levels, indicating ground water recharged by the river and cooling pond eventually will move east in the direction of the Truckee River.

\section{Springs}

Fewer than 50 springs are indicated on USGS topographic maps (1:24,000 scale) for the Tracy Segment, and most are located in upland areas, particularly along Long Valley and Lousetown Creeks (fig. 1). Under pre-development conditions, spring discharge supported small areas of phreatophytes near the point of discharge and water that was not consumed by ET returned to the subsurface by infiltration. Applications for water rights on spring discharge have been made to the Nevada Division of Water Resources for 14 locations, totaling about $12 \mathrm{ft}^{3} / \mathrm{s}$. Two of these applications received vested water rights of about $26 \mathrm{acre-ft/yr}$ for stock watering and two others received certificated water rights of about 11 acre-ft/yr for stock watering. Applications for water rights for two other springs made for almost $800 \mathrm{acre}-\mathrm{ft} / \mathrm{yr}$ for industrial use are pending. The remaining 8 applications were either cancelled or withdrawn (Mark Beutner, Nevada Division of Water Resources, written commun., 2000). Although conditions were drier than average during this study, total spring discharge for the Tracy Segment was estimated to be less than 2,000 acre-ft/yr.

\section{Water Chemistry}

Ground-water samples were collected to evaluate inorganic chemical quality in terms of Nevada drinking-water standards (table 12). Analytical results were compared with the National Primary standards [Maximum Contaminant Levels (MCLs)]. Nevada primary drinking water standards follow the National MCLs. Secondary standards [Secondary Maximum Contaminant Levels (SMCLs)] are non-enforceable guidelines for contaminants that may have cosmetic or aesthetic effects.

Selected analytes were used to constrain estimates of recharge, to evaluate exchange between ground water and Truckee River water, and to estimate the age of ground water. Surface-water samples were collected to evaluate exchange between ground water and Truckee River water. Results of the water analyses are summarized in table 13 . Historical waterquality data for samples collected from the Truckee River at Clark (station number 10350500) are summarized in table 14 and were used to characterize the chemistry of the Truckee River in the Tracy Segment during water years 1991-2003.

\section{Major lons}

Concentrations of dissolved solids in 11 ground-water samples ranged from $160 \mathrm{mg} / \mathrm{L}$ at site 22 to $2,000 \mathrm{mg} / \mathrm{L}$ at site 47 . The dissolved solids concentration at site 47 exceeded the Nevada SMCL (table 12) by $1,000 \mathrm{mg} / \mathrm{L}$, and at site 19 the National SMCL was exceeded by $32 \mathrm{mg} / \mathrm{L}$. Geothermal influence may be responsible for the higher dissolved-solids concentrations in these wells. Site 47 produces water that is $26^{\circ} \mathrm{C}$ and is a deep $(>500 \mathrm{ft})$ domestic well believed to be completed in Lake Lahontan deposits. Site 19 produces water that is $19.5^{\circ} \mathrm{C}$ and is an observation well completed in fractured metavolcanic rock to $167 \mathrm{ft}$ below land surface.

Concentrations of dissolved solids in 80 Truckee River water samples ranged from $63 \mathrm{mg} / \mathrm{L}$ to $394 \mathrm{mg} / \mathrm{L}$ (table 14), with no sample exceeding the National SMCL. Only 14 of the 80 analyses were greater than $200 \mathrm{mg} / \mathrm{L}$, and all were associated with streamflow discharge less than $200 \mathrm{ft}^{3} / \mathrm{s}$. The following regression relation (equation 5) between 79 logarithmtransformed dissolved-solids concentration $\left(\log _{10} \mathrm{C}_{\mathrm{DS}}\right)$ and streamflow discharge $(\mathrm{Q})$ values accounted for 83 percent $\left(\mathrm{R}^{2}\right.$ $=0.83)$ of the variability in dissolved-solids concentrations.

$$
\log _{10} C_{\mathrm{DS}}=3.188-0.377 \times\left(\log _{10} Q\right)
$$

Comparison of samples from ground water and Truckee River water in the Tracy Segment indicated, in general, that the Truckee River is more dilute than ground water, but concentrations overlap frequently, particularly for river samples collected at low flow and ground-water samples near recharge areas. Seven of the 11 ground-water samples had dissolvedsolids concentrations $(162-312 \mathrm{mg} / \mathrm{L})$ that are less than the maximum concentration in Truckee River samples (394 $\mathrm{mg} / \mathrm{L}$ ). Three of seven ground-water samples were collected from shallow observation wells near irrigated fields, two were near a losing reach of the Truckee River, and two others were in upland areas away from the river.

The MCLs for major ions were not exceeded in any of the ground-water samples collected from the Tracy Segment. The Nevada SMCL for fluoride was exceeded at sites $47(3 \mathrm{mg} / \mathrm{L})$, $19(2.4 \mathrm{mg} / \mathrm{L})$, and $20(2.2 \mathrm{mg} / \mathrm{L})$. The National SMCL for sulfate was exceeded at site $47(356 \mathrm{mg} / \mathrm{L})$. One field $\mathrm{pH}$ measurement exceeded the Nevada SMCL (site 22; 6.0 standard units). No Truckee River sample exceeded the MCL or Nevada SMCL for major ions.

Sodium is the dominant cation in samples from five wells and is co-dominant with calcium in four other wells. Bicarbonate is the dominant anion in samples from nine wells and is codominant with sulfate in samples from sites 21 and 22. Water from site 23 and site 24 contains calcium and magnesium as co-dominant cations and bicarbonate as the dominant anion. In 86 analyses of Truckee River water, sodium and calcium are co-dominant cations and bicarbonate is the dominant anion. Relative similarity of major-ion chemistry in most available ground-water and surface-water samples limits the value of these data for evaluating interactions between the two waters. 


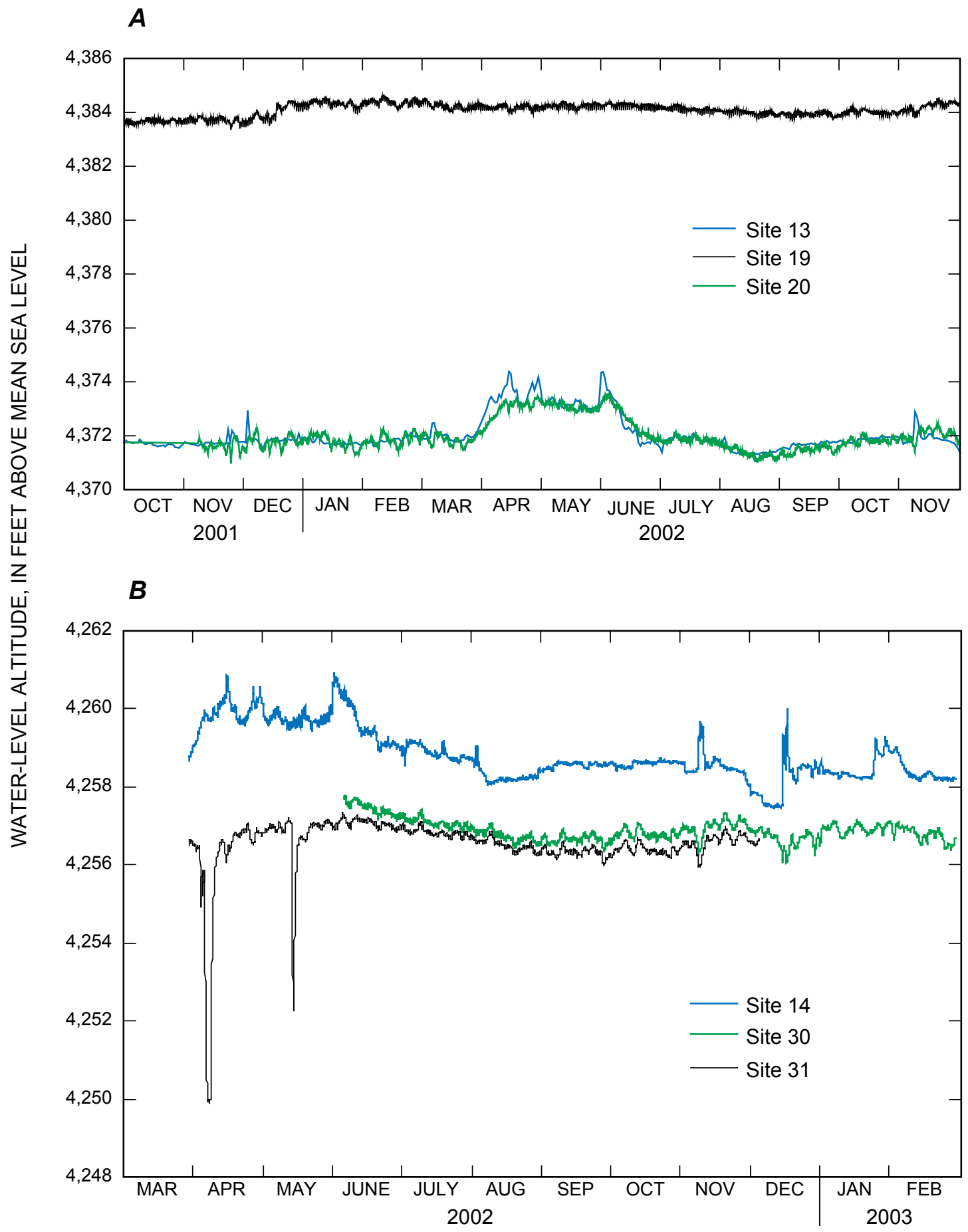

Figure 11. Relation between water-level fluctuations in nearby wells and Truckee River stage measured at U.S. Geological Survey streamflow-gaging station at Site 13 and near Site 14 (table 1), Tracy Segment Hydrographic Area, west-central Nevada. 
Table 12. Nevada safe drinking-water standards

$[\mathrm{mg} / \mathrm{L}$, milligrams per liter; as $\mathrm{N}$, as nitrogen; $\mu \mathrm{g} / \mathrm{L}$, micrograms per liter. Symbol: - , no standard established]

\begin{tabular}{|c|c|c|c|}
\hline Property or constituent & $\begin{array}{l}\text { Primary' } \\
\text { maximum }\end{array}$ & $\begin{array}{c}\text { Secondary } \\
\text { maximum }\end{array}$ & $\begin{array}{l}\text { Preferred }^{1} \\
\text { maximum }\end{array}$ \\
\hline $\begin{array}{l}\text { Dissolved solids } \\
\quad(\mathrm{mg} / \mathrm{L})\end{array}$ & - & 1,000 & 500 \\
\hline $\mathrm{pH}$ (standard units) & - & $6.5-8.5$ & $6.5-8.5$ \\
\hline Magnesium (mg/L) & - & 150 & 125 \\
\hline Sulfate (mg/L) & - & 500 & 250 \\
\hline Chloride (mg/L) & - & 400 & 250 \\
\hline Fluoride (mg/L) & 4 & 2 & 2 \\
\hline Nitrate (mg/L as N) & 10 & - & - \\
\hline Nitrite (mg/L as N) & 1 & - & - \\
\hline $\begin{array}{l}\text { Nitrate }+ \text { Nitrite }(\mathrm{mg} / \mathrm{L} \\
\text { as } N)\end{array}$ & 10 & - & - \\
\hline Aluminum $(\mu \mathrm{g} / \mathrm{L})$ & - & - & $50-200$ \\
\hline Antimony $(\mu \mathrm{g} / \mathrm{L})$ & 6 & - & - \\
\hline Arsenic $(\mu \mathrm{g} / \mathrm{L})$ & ${ }^{3} 50$ & - & - \\
\hline Barium $(\mu \mathrm{g} / \mathrm{L})$ & 2,000 & - & - \\
\hline Beryllium ( $\mu \mathrm{g} / \mathrm{L})$ & 4 & - & - \\
\hline Cadmium ( $\mu \mathrm{g} / \mathrm{L})$ & 5 & - & - \\
\hline Chromium ( $\mu \mathrm{g} / \mathrm{L})$ & 100 & - & - \\
\hline Copper $(\mu \mathrm{g} / \mathrm{L})$ & 1,300 & 1,000 & - \\
\hline Iron $(\mu \mathrm{g} / \mathrm{L})$ & - & 600 & 300 \\
\hline Lead $(\mu \mathrm{g} / \mathrm{L})$ & 15 & - & - \\
\hline Manganese $(\mu \mathrm{g} / \mathrm{L})$ & - & 100 & 50 \\
\hline Mercury ( $\mu \mathrm{g} / \mathrm{L})$ & 2 & - & - \\
\hline Nickel $(\mu \mathrm{g} / \mathrm{L})$ & - & 100 & - \\
\hline Selenium $(\mu \mathrm{g} / \mathrm{L})$ & 50 & - & - \\
\hline Silver $(\mu \mathrm{g} / \mathrm{L})$ & - & - & 100 \\
\hline Thallium ( $\mu \mathrm{g} / \mathrm{L})$ & 2 & - & - \\
\hline${ }^{4}$ Uranium $(\mu \mathrm{g} / \mathrm{L})$ & 30 & - & - \\
\hline Zinc $(\mu \mathrm{g} / \mathrm{L})$ & - & 5,000 & 5,000 \\
\hline
\end{tabular}

${ }^{1}$ Accessed at http://www.epa.gov/safewater/mcl.html\#8 on 12/4/03

${ }^{2}$ Accessed at http://health2k.state.nv.us/bhps/pHe/sdwpdocs on 12/4/03

${ }^{3}$ Federal maximum contaminant level to be lowered to $10 \mu \mathrm{g} / \mathrm{L}$ on $1 / 23 / 06$

${ }^{4}$ New Federal maximum contaminant level effective 12/8/03
The range in concentrations of chloride in ground water $(3.5$ $\mathrm{mg} / \mathrm{L}$ to $83 \mathrm{mg} / \mathrm{L}$ ) suggests that "internal" sources of chloride may invalidate assumptions of the chloride-balance approach (Dettinger, 1989) to estimating ground-water recharge.

\section{Trace Elements and Radon Gas}

The current MCL (2005) for arsenic $(50 \mu \mathrm{g} / \mathrm{L})$ was exceeded in water samples collected from site $19(214 \mu \mathrm{g} / \mathrm{L})$ and site $51(103 \mu \mathrm{g} / \mathrm{L})$. In January 2006, the MCL will be lowered to $10 \mu \mathrm{g} / \mathrm{L}$ (Accessed at http://www.epa.gov/safewater/mcl.html\#8 on 12/4/03), which is less than or equal to concentrations measured in samples collected from sites $20(39 \mu \mathrm{g} / \mathrm{L}), 21(30 \mu \mathrm{g} / \mathrm{L}), 47(18 \mu \mathrm{g} / \mathrm{L})$, and $24(10 \mu \mathrm{g} / \mathrm{L})$. Arsenic is naturally occurring in rocks and soil and commonly enriched in Tertiary volcanic rock and lake deposits of western Nevada. The new federal MCL is anticipated to affect 80 to 100 community water systems in Nevada (Bortolin, 2003) including the system supplied by site 21 . No other trace element exceeded its MCL in ground-water samples collected in the Tracy Segment (table 13).

Four trace elements have SMCLs established by the State of Nevada (table 12) for aesthetic reasons (taste, mineralization, and porcelain staining). The Nevada SMCL for manganese $(100 \mu \mathrm{g} / \mathrm{L})$ was exceeded at sites $49(233 \mu \mathrm{g} / \mathrm{L})$ and $21(148 \mu \mathrm{g} / \mathrm{L})$. The National SMCL for iron $(300 \mu \mathrm{g} / \mathrm{L})$ was exceeded at site $49(340 \mu \mathrm{g} / \mathrm{L})$. No other trace element exceeded National or Nevada SMCLs.

Radon is a naturally occurring radioactive gas that has received attention from health officials due to its potential to cause lung cancer (Cothern, 1987, p. 7). Radon released from water to unventilated indoor airspace is facilitated by common activities, such as showering or laundering (Lowry and others, 1987, p. 363). Radon activities measured in 278 wells and springs located in several HAs of Nevada ranged from $<80 \mathrm{pCi} / \mathrm{L}$ to $16,000 \mathrm{pCi} / \mathrm{L}$, with the median activity being $766 \mathrm{pCi} / \mathrm{L}$ (Lico, 1992, p. 8). No regulations of radon in community water supplies have been established, but the EPA has proposed an MCL of $300 \mathrm{pCi} / \mathrm{L}$ with an alternate MCL of $4,000 \mathrm{pCi} / \mathrm{L}$ for community water systems that implement an approved multimedia mitigation program to limit radon activities in indoor airspace (U.S. Environmental Protection Agency, 1999). Radon activity measured in all ground-water samples collected from the Tracy Segment exceeded the proposed MCL (370 to $1,600 \mathrm{pCi} / \mathrm{L}$; table 13 ), but community supply wells will be eligible to mitigate indoor concentrations under the alternate MCL.

\section{Ratios of Oxygen and Hydrogen Stable Isotopes}

The isotopic composition of water (hydrogen and oxygen) can be measured to evaluate hydrologic processes, such as mixing of water sources and the removal of a portion of the water by evaporation. Results are ratios of each element's stable isotopes $\left({ }^{18} \mathrm{O} /{ }^{16} \mathrm{O}\right.$ and $\left.{ }^{2} \mathrm{H} /{ }^{1} \mathrm{H}\right)$ and reported in permil $(\%$, 
Table 13. Statistical summary of ground-water quality data, Tracy Segment Hydrographic Area, west-central Nevada, 2001-2003

[Concentrations are in milligrams per liter unless otherwise noted. Abbreviations: $\mu \mathrm{S} / \mathrm{cm}$, microsiemens per centimeter; ${ }^{\circ} \mathrm{C}$, degrees centigrade; $\mathrm{N}$, nitrogen; $\mathrm{P}$, phosphorus; $\mu \mathrm{g} / \mathrm{L}$, micrograms per liter; $\mathrm{pCi} / \mathrm{L}$, picocuries per liter; permil, parts per thousand; NA, not applicable; $<$, less than.]

\begin{tabular}{|c|c|c|c|c|c|}
\hline Constituent or property & $\begin{array}{c}\text { Number of } \\
\text { determinations }\end{array}$ & $\begin{array}{l}\text { Number of } \\
\text { determinations } \\
\text { less than } \\
\text { analytical } \\
\text { reporting limit }\end{array}$ & Mean & Minimum & Maximum \\
\hline Specific conductance $(\mu \mathrm{S} / \mathrm{cm})$ & 11 & 0 & 710 & 210 & 3,300 \\
\hline $\mathrm{pH}$ (standard units) & 11 & 0 & 7.3 & 6.0 & 8.5 \\
\hline Water temperature $\left({ }^{\circ} \mathrm{C}\right)$ & 11 & 0 & 17.5 & 13.5 & 26.0 \\
\hline Dissolved oxygen & 8 & 0 & 1.8 & 0.01 & 5.8 \\
\hline Calcium & 11 & 0 & 19 & 5.0 & 38 \\
\hline Magnesium & 11 & 0 & 8.0 & 0.53 & 18 \\
\hline Sodium & 11 & 0 & 120 & 12 & 730 \\
\hline Potassium & 11 & 0 & 4.8 & 1.9 & 7.1 \\
\hline Bicarbonate & 11 & 0 & 270 & 71 & 1,400 \\
\hline Carbonate & 11 & 11 & NA & $<2$ & $<2$ \\
\hline Alkalinity & 11 & 0 & 220 & 58 & 1,100 \\
\hline Sulfate & 11 & 0 & 78 & 12 & 360 \\
\hline Chloride & 11 & 0 & 27 & 3.5 & 83 \\
\hline Fluoride & 11 & 4 & NA & $<0.17$ & 3.0 \\
\hline Bromide & 11 & 0 & 0.09 & 0.03 & 0.23 \\
\hline Silica & 11 & 0 & 42 & 20 & 69 \\
\hline Dissolved solids & 11 & 0 & 450 & 160 & 2,000 \\
\hline Nitrate (as N) & 11 & 7 & NA & $<0.05$ & 3.0 \\
\hline Nitrite (as N) & 11 & 11 & $\mathrm{NA}$ & $<0.008$ & $<0.008$ \\
\hline Ammonia (as N) & 11 & 10 & NA & $<0.04$ & 0.09 \\
\hline Orthophosphate (as P) & 11 & 1 & NA & $<0.007$ & 0.18 \\
\hline Organic nitrogen (as N) & 11 & 11 & $\mathrm{NA}$ & $<0.10$ & $<0.10$ \\
\hline Aluminum $(\mu \mathrm{g} / \mathrm{L})$ & 11 & 6 & NA & $<1.6$ & 7.0 \\
\hline Antimony $(\mu \mathrm{g} / \mathrm{L})$ & 11 & 5 & $\mathrm{NA}$ & $<0.05$ & 1.1 \\
\hline Arsenic $(\mu \mathrm{g} / \mathrm{L})$ & 11 & 0 & 40 & 2.5 & 210 \\
\hline Barium ( $\mu \mathrm{g} / \mathrm{L})$ & 11 & 0 & 45 & 12 & 140 \\
\hline Beryllium $(\mu \mathrm{g} / \mathrm{L})$ & 11 & 11 & NA & $<0.06$ & $<0.06$ \\
\hline Boron $(\mu \mathrm{g} / \mathrm{L})$ & 11 & 0 & 620 & 24 & 2,500 \\
\hline Cadmium $(\mu \mathrm{g} / \mathrm{L})$ & 11 & 9 & NA & $<0.04$ & 0.13 \\
\hline Chromium $(\mu \mathrm{g} / \mathrm{L})$ & 11 & 8 & NA & $<0.80$ & 1.5 \\
\hline Cobalt $(\mu \mathrm{g} / \mathrm{L})$ & 11 & 1 & NA & $<0.014$ & 0.69 \\
\hline Copper $(\mu \mathrm{g} / \mathrm{L})$ & 11 & 1 & $\mathrm{NA}$ & $<0.40$ & 3.9 \\
\hline $\operatorname{Iron}(\mu \mathrm{g} / \mathrm{L})$ & 11 & 7 & NA & $<10$ & 340 \\
\hline Lead $(\mu \mathrm{g} / \mathrm{L})$ & 11 & 9 & NA & $<0.08$ & 1.4 \\
\hline Lithium $(\mu \mathrm{g} / \mathrm{L})$ & 11 & 0 & 110 & 7.9 & 920 \\
\hline Manganese ( $\mu \mathrm{g} / \mathrm{L})$ & 11 & 2 & NA & $<2.0$ & 230 \\
\hline Mercury $(\mu \mathrm{g} / \mathrm{L})$ & 11 & 9 & NA & $<0.018$ & 0.04 \\
\hline Molybdenum $(\mu \mathrm{g} / \mathrm{L})$ & 11 & 0 & 8.3 & 0.80 & 45 \\
\hline $\operatorname{Nickel}(\mu \mathrm{g} / \mathrm{L})$ & 11 & 0 & 0.93 & 0.08 & 2.4 \\
\hline Selenium $(\mu \mathrm{g} / \mathrm{L})$ & 11 & 7 & NA & $<0.30$ & 1.3 \\
\hline Silver $(\mu \mathrm{g} / \mathrm{L})$ & 11 & 11 & NA & $<0.20$ & $<1.0$ \\
\hline Strontium $(\mu \mathrm{g} / \mathrm{L})$ & 11 & 0 & 250 & 86 & 540 \\
\hline Thallium $(\mu \mathrm{g} / \mathrm{L})$ & 11 & 7 & NA & $<0.04$ & 0.07 \\
\hline Vanadium $(\mu \mathrm{g} / \mathrm{L})$ & 11 & 0 & 14 & 0.30 & 60 \\
\hline $\operatorname{Zinc}(\mu \mathrm{g} / \mathrm{L})$ & 11 & 1 & NA & $<2.0$ & 280 \\
\hline Uranium $(\mu \mathrm{g} / \mathrm{L})$ & 11 & 0 & 1.9 & 0.07 & 8.4 \\
\hline Radon $222(\mathrm{pCi} / \mathrm{L})$ & 11 & 0 & 870 & 370 & 1,600 \\
\hline Deuterium/Protium (permil) & 11 & 0 & -101 & -125 & -81 \\
\hline${ }^{18}$ Oxygen/16 Oxygen (permil) & 11 & 0 & -13 & -16 & -10 \\
\hline
\end{tabular}


Table 14. Statistical summary of surface-water quality data, U.S. Geological Survey Station Number 10350500, Truckee River at Clark, Tracy Segment Hydrographic Area, west-central Nevada, 1991-2003

[Concentrations are in milligrams per liter unless otherwise noted. Abbreviations: $\mu \mathrm{S} / \mathrm{cm}$, microsiemens per centimeter; ${ }^{\circ} \mathrm{C}$, degrees centigrade; $\mathrm{N}$, nitrogen; P, phosphorus; $\mu \mathrm{g} / \mathrm{L}$, micrograms per liter; $\mathrm{pCi} / \mathrm{L}$, picocuries per liter; permil, parts per thousand; NA, not applicable; <, less than.]

\begin{tabular}{|c|c|c|c|c|c|}
\hline Constituent or property & $\begin{array}{l}\text { Number of deter- } \\
\text { minations }\end{array}$ & $\begin{array}{l}\text { Number of deter- } \\
\text { minations less } \\
\text { than analytical } \\
\text { reporting limit }\end{array}$ & Mean & Minimum & Maximum \\
\hline Specific conductance $(\mu \mathrm{S} / \mathrm{cm})$ & 107 & 0 & 253 & 94 & 668 \\
\hline $\mathrm{pH}$ (standard units) & 106 & 0 & 8.0 & 6.8 & 9.3 \\
\hline Water temperature $\left({ }^{\circ} \mathrm{C}\right)$ & 112 & 0 & 12.5 & 1.0 & 25.5 \\
\hline Dissolved oxygen & 110 & 0 & 9.9 & 6.3 & 15.6 \\
\hline Calcium & 86 & 0 & 19 & 7 & 41 \\
\hline Magnesium & 86 & 0 & 6.4 & 2.2 & 14.1 \\
\hline Sodium & 86 & 0 & 24 & 6 & 69 \\
\hline Potassium & 86 & 0 & 4.0 & 1.4 & 12 \\
\hline Bicarbonate & 102 & 0 & 88 & 38 & 190 \\
\hline Carbonate & 9 & 2 & NA & $<2$ & 17 \\
\hline Alkalinity & 103 & 0 & 73 & 31 & 160 \\
\hline Sulfate & 112 & 0 & 21 & 0.1 & 67 \\
\hline Chloride & 113 & 0 & 20 & 4 & 65 \\
\hline Fluoride & 80 & 32 & NA & $<0.1$ & 0.3 \\
\hline Silica & 86 & 0 & 19 & 3 & 35 \\
\hline Dissolved solids & 80 & 0 & 160 & 63 & 394 \\
\hline Nitrate plus Nitrite (as N) & 112 & 39 & NA & $<0.05$ & 4.3 \\
\hline Nitrite (as N) & 112 & 73 & NA & $<0.008$ & 0.26 \\
\hline Ammonia (as $\mathrm{N}$ ) & 112 & 49 & NA & $<0.04$ & 2.9 \\
\hline Orthophosphate (as P) & 112 & 13 & NA & $<0.007$ & .18 \\
\hline Organic nitrogen (as $\mathrm{N}$ ) & 80 & 7 & NA & $<0.10$ & 3.4 \\
\hline Aluminum $(\mu \mathrm{g} / \mathrm{L})$ & 7 & 1 & NA & $<1.6$ & 48 \\
\hline Antimony $(\mu \mathrm{g} / \mathrm{L})$ & 7 & 7 & NA & $<0.05$ & $<0.05$ \\
\hline Arsenic $(\mu \mathrm{g} / \mathrm{L})$ & 7 & 0 & 10 & 3 & 15 \\
\hline Barium $(\mu \mathrm{g} / \mathrm{L})$ & 7 & 0 & 44 & 21 & 65 \\
\hline Beryllium $(\mu \mathrm{g} / \mathrm{L})$ & 7 & 7 & NA & $<0.06$ & $<0.06$ \\
\hline Cadmium $(\mu \mathrm{g} / \mathrm{L})$ & 7 & 7 & NA & $<0.04$ & $<0.04$ \\
\hline Chromium $(\mu \mathrm{g} / \mathrm{L})$ & 7 & 1 & NA & $<0.80$ & 1 \\
\hline Cobalt $(\mu \mathrm{g} / \mathrm{L})$ & 7 & 7 & NA & $<0.014$ & $<0.014$ \\
\hline Copper $(\mu \mathrm{g} / \mathrm{L})$ & 7 & 2 & NA & $<0.40$ & 3 \\
\hline Iron $(\mu \mathrm{g} / \mathrm{L})$ & 80 & 2 & NA & $<10$ & 77 \\
\hline Lead $(\mu \mathrm{g} / \mathrm{L})$ & 7 & 7 & NA & $<0.08$ & $<0.08$ \\
\hline Manganese $(\mu \mathrm{g} / \mathrm{L})$ & 80 & 0 & 19 & 4 & 86 \\
\hline Molybdenum $(\mu \mathrm{g} / \mathrm{L})$ & 7 & 0 & 6 & 1 & 11 \\
\hline Nickel ( $\mu \mathrm{g} / \mathrm{L})$ & 7 & 2 & NA & $<0.08$ & 2 \\
\hline Selenium $(\mu \mathrm{g} / \mathrm{L})$ & 11 & 7 & NA & $<0.30$ & 1.3 \\
\hline Silver $(\mu \mathrm{g} / \mathrm{L})$ & 7 & 7 & NA & $<0.20$ & $<0.20$ \\
\hline $\operatorname{Zinc}(\mu \mathrm{g} / \mathrm{L})$ & 7 & 0 & 3 & 2 & 4 \\
\hline Uranium $(\mu \mathrm{g} / \mathrm{L})$ & 7 & 2 & NA & $<0.05$ & 3 \\
\hline Deuterium/Protium (permil) & 4 & 0 & -78.6 & -79.8 & -77.2 \\
\hline${ }^{18}$ Oxygen $/{ }^{16}$ Oxygen (permil) & 4 & 0 & -9.32 & -9.38 & -9.26 \\
\hline
\end{tabular}


parts per thousand) relative to Vienna Standard Mean Ocean Water (VSMOW; Coplen, 1994). By convention, isotopic results are expressed as "delta oxygen-18" $\left(\delta^{18} \mathrm{O}\right)$ and "delta deuterium" $\left(\delta^{2} \mathrm{H}\right)$. A negative delta value indicates that the sample is isotopically "lighter" than the reference standard VSMOW (that is, the sample has a smaller proportion of ${ }^{18} \mathrm{O}$ or ${ }^{2} \mathrm{H}$ relative to ${ }^{16} \mathrm{O}$ or ${ }^{1} \mathrm{H}$, than proportions of VSMOW) and a positive delta value indicates the sample is "heavier" than VSMOW.

The isotopic composition of precipitation typically varies between storms and from place to place due to temperature and moisture content of storm clouds, but the global average composition of precipitation is described by the linear regression equation (Craig, 1961):

$$
\delta^{2} \mathrm{H}=8 \times\left(\delta^{18} \mathrm{O}\right)+10
$$

The isotopic composition of ground-water recharge in northern Nevada was described by the regression equation of the isotopic composition of 206 ground-water samples that had chloride concentrations less than $25 \mathrm{mg} / \mathrm{L}$ (Welch and others, 1997, p. A14):

$$
\delta^{2} \mathrm{H}=6.94 \times\left(\delta^{18} \mathrm{O}\right)-10.6
$$

The $25 \mathrm{mg} / \mathrm{L}$ chloride concentration was selected as a criterion to indicate minimal evaporation. Evaporation causes the heavier isotopes $\left({ }^{18} \mathrm{O}\right.$ and $\left.{ }^{2} \mathrm{H}\right)$ to preferentially accumulate in the liquid phase of water and the lighter isotopes $\left({ }^{16} \mathrm{O}\right.$ and ${ }^{1} \mathrm{H}$ ) tend to accumulate in the vapor phase. Water in the Truckee River is isotopically heavier than precipitation and local ground water because of evaporation from upstream reservoirs, mainly Lake Tahoe.

Figure 12 shows the relation of stable-isotope values for ground-water and Truckee River water samples from the Tracy Segment. $\delta^{2} \mathrm{H}$ and $\delta^{18} \mathrm{O}$ in samples from the Truckee River ranged from -79.8 to $-77.2 \%$ and from -9.38 to $-9.26 \%$, respectively (table 14). $\delta^{2} \mathrm{H}$ or $\delta^{18} \mathrm{O}$ in 11 ground-water samples ranged from -125.1 to $-81.2 \%$ and from -15.81 to $-9.8 \%$, respectively. The three lighter (more negative) points on the lower left of figure 12 represent local ground water and the four heaviest (less negative) points on the upper right represent samples collected from the Truckee River in the Tracy Segment. Two samples are from wells in recharge areas away from the Truckee River (sites 23 and 40) and site 49 is about $0.25 \mathrm{mi}$ north of the river; all three sites have water levels higher than mean river stage and are located where the Truckee River gains streamflow (table 11).

Proportions of two sources of water that have different isotopic compositions can be estimated by computing a linear mixing line between isotopic values of each contributing end member. Stable isotope values for eight ground-water samples collected in the Tracy Segment fall along a mixing line between local ground water and Truckee River water (fig. 12). The amount of water contributed by Truckee River water (A) can be computed by solving the equation:

$$
\delta_{(\text {site })}=A \times \delta_{(\text {Truckee River })}+(1-A) \times \delta_{(\text {local recharge })}
$$

The delta $(\delta)$ represents either $\delta^{2} \mathrm{H}$ or $\delta^{18} \mathrm{O}$ and the parenthetic subscripts indicate the source of each value. The average value of $\delta^{2} \mathrm{H}$ or $\delta^{18} \mathrm{O}$ for Truckee River water and local ground water (sites 23,40 , and 49 ) are -78.6 or $-9.32 \%$, and -121.8 or $-15.4 \%$, respectively. Values for $\delta_{(\text {site })}$ are values of $\delta^{2} \mathrm{H}$ or $\delta^{18} \mathrm{O}$ specific for each site and are listed in table 15 along with calculated percent contribution by river water.

\section{Estimates of Recharge, Discharge, and Subsurface Flow}

Ground water in the Tracy Segment is recharged by infiltration of precipitation, by seepage of streamflow through streambeds of the Truckee River, and ephemeral channels. Agricultural practices have introduced recharge from the Truckee Canal and other irrigation ditches and by irrigation water applied in excess of crop-consumptive use. Infiltration of cooling water used at the Tracy Power Station, treated wastewater effluent stored in holding ponds, and leachate from individual domestic-wastewater disposal systems also contribute recharge. Ground water is discharged from the subsurface by pumping and flowing wells, by seepage to the Truckee River, by phreatophytic ET, and by springs. Ground-water flow across hydrographic boundaries also can be significant to ground-water budget calculations. Estimates of these components of the ground-water budget are provided in the following sections.

\section{Recharge}

Estimates of ground-water recharge from precipitation that falls within the Tracy Segment were made using empirical and mass-balance methods and ranged from 2,000 acre-ft/yr to 22,000 acre-ft/yr (table 16). Streamflow in the Truckee River gains a net 11,000 acre-ft/yr through the Tracy Segment, but 61,000 acre- $\mathrm{ft} / \mathrm{yr}$ is lost between the streamflow-gaging station near Tracy (site 14) and the two stations below Derby Dam (sites 16 and 17). Recharge from seepage loss from the Truckee Canal (9,000 acre-ft/yr) and irrigation water applied in excess of crop-consumptive use (4,000 acre-ft/yr) contributed about 13,000 acre-ft/yr to ground-water recharge, and secondary recharge contributed less than 1,000 acre-ft/yr.

\section{Empirical Estimates}

Mean annual recharge estimated by the Maxey-Eakin method was 6,000 acre-ft/yr using coefficients of zero recharge for the zone with less than 8 in. of precipitation, 3 percent for 8-12 in., 7 percent for 12-15 in., 15 percent for 15-20 in., and 25 percent for more than 20 in. (VanDenburgh 


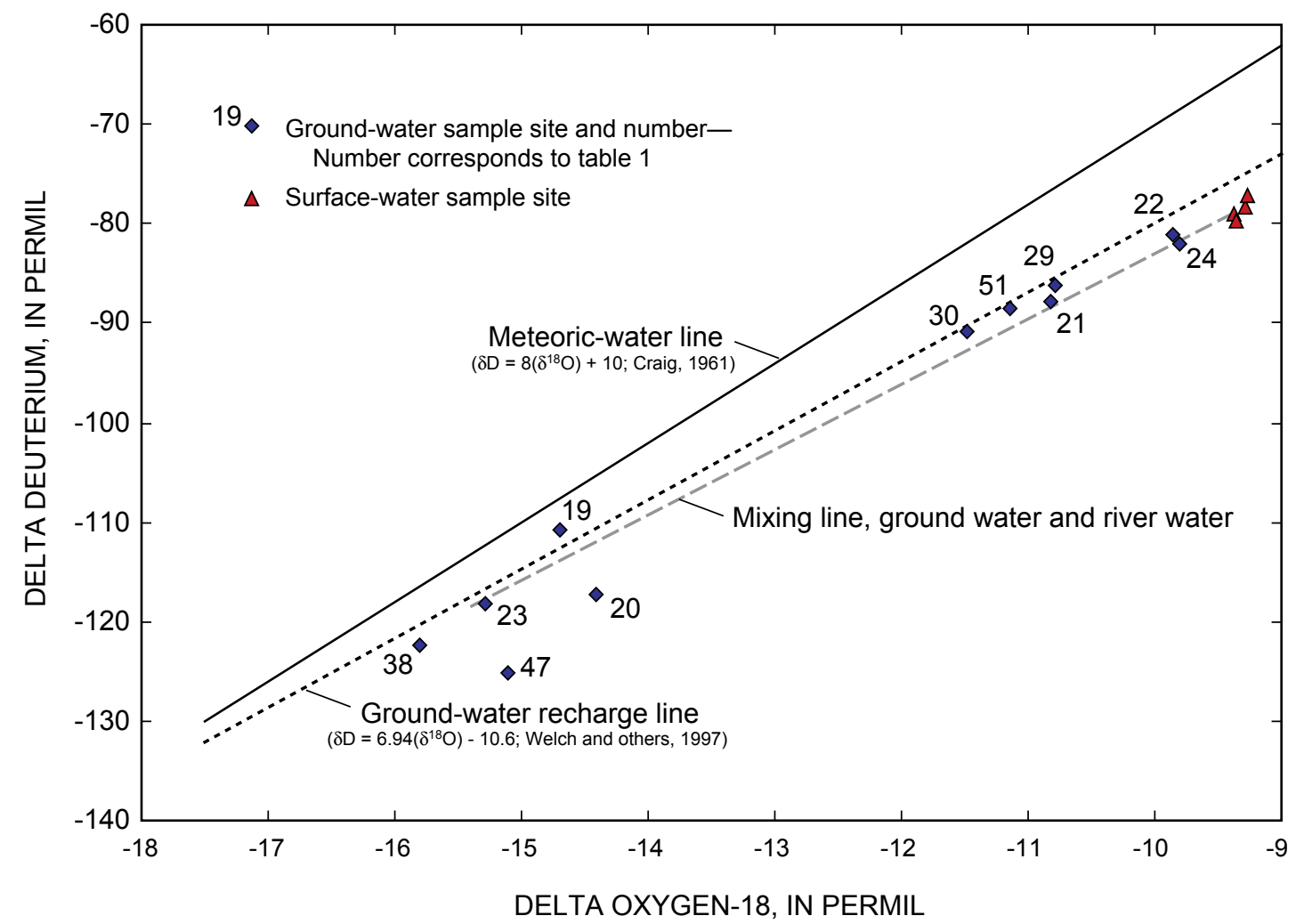

Figure 12. Relation of deuterium to oxygen-18 for selected ground-water and Truckee River water samples, Tracy Segment Hydrographic Area, west-central Nevada.

Table 15. Percent composition of local recharge water and Truckee River water estimated from stable isotopic mixing for ground-water samples collected in the Tracy Segment Hydrographic Area, west-central Nevada

\begin{tabular}{ccccc}
\hline $\begin{array}{c}\text { End member or } \\
\text { site number } \\
\text { (figure 2) }\end{array}$ & Permil & $\begin{array}{c}\text { Delta oxygen-18 } \\
\text { 1Percent Truckee } \\
\text { River water }\end{array}$ & Permil & $\begin{array}{c}\text { Delta deuterium } \\
\text { 'Percent Truckee } \\
\text { River water }\end{array}$ \\
\hline $\begin{array}{c}\text { Local recharge } \\
\text { Truckee River }\end{array}$ & -15.4 & 0 & -121.8 & 0 \\
19 & -9.32 & 100 & -78.6 & 100 \\
20 & -14.7 & 12 & -110.7 & 26 \\
21 & -14.41 & 16 & -117.2 & 11 \\
22 & -10.83 & 75 & -87.9 & 78 \\
26 & -9.85 & 91 & -81.2 & 94 \\
29 & -9.8 & 92 & -82.0 & 92 \\
30 & -10.79 & 76 & -86.1 & 83 \\
53 & -11.48 & 64 & -90.8 & 72 \\
\hline
\end{tabular}

${ }^{1}$ Estimated by the equation: $100 \times \delta_{\text {Site }}=A x \delta_{\text {Truckee River }}+(1-A) \times \delta_{\text {Local recharge }}$; where Site is the isotopic ratio measured in sample water, $\delta_{\text {Truckee River }}$ is the average of four isotopic ratios collected from the Truckee River, and $\delta_{\text {Local recharge }}$ is the average of three isotopic ratios collected from wells (sites 23,40 , and 49 ; table 1 ) away from the river. 
and others, 1973, p. 40). Mean-annual recharge estimated by the Nichols method (Nichols, 2000, p. C21; Harrill and others, 1988) was 19,000 acre-ft/yr, using percentages of mean-annual precipitation of 0.8 percent for precipitation between 8 to less than 12 in., 13 percent for 12 to less than 16 in., 14.4 percent for 16 to less than $20 \mathrm{in}$., and 15.8 percent for areas receiving 20 to 34 in. of mean-annual precipitation.

\section{Chloride-Mass Balance}

Estimated ground-water recharge by chloride-mass balance is $6,000-8,000$ acre-ft/yr (table 16), using concentrations of chloride dissolved in ground-water samples. Chloride in 11 ground-water samples collected during this study ranged from $3.5 \mathrm{mg} / \mathrm{L}$ at site 23 to $83 \mathrm{mg} / \mathrm{L}$ at site 49 , and the median concentration was $16.5 \mathrm{mg} / \mathrm{L}$. Application of these values to equation 1 yields recharge estimates that range from less than 0.5 (1,000 acre-ft/yr) to almost 12 percent $(23,000 \mathrm{acre}-\mathrm{ft} / \mathrm{yr})$ of mean-annual precipitation and the median chloride concentration yields a recharge estimate of 2.4 percent $(4,000-5,000$ acre-ft/yr). However, eight of these ground-water samples contained more than 10 percent river water (table 15). Because the median chloride concentration in Truckee River water was $15.9 \mathrm{mg} / \mathrm{L}$, the river contributes enough chloride in the eight samples to invalidate their use for this chloride-mass balance approach. Site 23 at an altitude of about $5,800 \mathrm{ft}$ had the smallest chloride concentration $(3.5 \mathrm{mg} / \mathrm{L})$ and a chloride ratio of 0.115 . Mean-annual precipitation estimated for areas above $6,000 \mathrm{ft}$ in the Tracy Segment ranged from about 49,000 to 64,000 acre-ft/yr and applying the chloride-mass balance ratio of 0.115 yields rates of recharge that ranged from 1.0 to 1.3 $\mathrm{ft} / \mathrm{yr}(5,600-7,400$ acre- $\mathrm{ft} / \mathrm{yr})$. Site 40 , at an altitude of 4,380 $\mathrm{ft}$, had a chloride concentration of $7.43 \mathrm{mg} / \mathrm{L}$ and a chloride

Table 16. Estimated mean annual recharge from precipitation, Tracy Segment Hydrographic Area, west-central Nevada

\begin{tabular}{|c|c|c|}
\hline \multirow{2}{*}{$\begin{array}{c}\text { Area } \\
\text { (acres) }\end{array}$} & \multicolumn{2}{|c|}{ Mean Annual Recharge } \\
\hline & $\begin{array}{l}\text { Percentage of } \\
\text { precipitation }\end{array}$ & $\begin{array}{l}\text { Total } \\
\text { (acre-feet per year) }\end{array}$ \\
\hline \multicolumn{3}{|c|}{ VanDenburgh and others, 1973} \\
\hline 188,000 & 4 & 6,000 \\
\hline \multicolumn{3}{|c|}{$\begin{array}{c}\text { Nichols, } 2000 \text { coefficients applied to } 1997 \text { Nevada } \\
\text { precipitation map }\end{array}$} \\
\hline 190,000 & 10 & 19,000 \\
\hline \multicolumn{3}{|c|}{$\begin{array}{l}\text { Subtraction of evapotranspiration and runoff from the precipitation } \\
\text { distribution of VanDenburgh and others, } 1973\end{array}$} \\
\hline 188,000 & 6 & 8,000 \\
\hline \multicolumn{3}{|c|}{$\begin{array}{l}\text { Subtraction of evapotranspiration and runoff from the } 1997 \\
\text { Nevada precipitation map }\end{array}$} \\
\hline 190,000 & 10 & 22,000 \\
\hline \multicolumn{3}{|c|}{$\begin{array}{l}\text { Subtraction of evapotranspiration and runoff from precipitation } \\
\text { estimated by Berger and others, } 1997\end{array}$} \\
\hline 190,000 & 2 & 2,000 \\
\hline
\end{tabular}

ratio of 0.054 . Application of the chloride ratio from site 40 to precipitation estimates $(121,000-151,000 \mathrm{acre}-\mathrm{ft} / \mathrm{yr})$ for the area above 5,000 ft (131,000-133,000 acres) yields estimated rates of mean-annual recharge that ranged from 0.05 to 0.06 $\mathrm{ft} / \mathrm{yr}(6,000-8,000$ acre-ft/yr).

Chloride concentrations in pore-water extracts ranged from $4.7 \mathrm{mg} / \mathrm{L}$ to $1,700 \mathrm{mg} / \mathrm{L}$ and averaged $134 \mathrm{mg} / \mathrm{L}$ (table 17). Chloride-distribution profiles in each of the six boreholes are shown in figure 13. Chloride concentrations in 68 samples collected from depths $10 \mathrm{ft}$ or greater ranged from $4.7 \mathrm{mg} / \mathrm{L}$ to $729 \mathrm{mg} / \mathrm{L}$ and average $104 \mathrm{mg} / \mathrm{L}$. Average chloride concentrations of samples from these depths for each individual borehole ranged from $8.6 \mathrm{mg} / \mathrm{L}$ for site 10 to $290 \mathrm{mg} / \mathrm{L}$ for site 8 . Chloride profiles were collected from altitudes between 4,400 to $5,600 \mathrm{ft}$ where annual precipitation is less than $17 \mathrm{in} / \mathrm{yr}$. The average chloride ratio (equation 1) from samples collected beneath $10 \mathrm{ft}$ is 0.015 indicating 1,000 to 2,000 acre- $\mathrm{ft} / \mathrm{yr}$ of ground-water recharge from precipitation on areas at altitudes less than $6,000 \mathrm{ft}$ (table 16), which represents about 1 percent of the mean-annual precipitation.

The distribution of chloride dissolved in pore water from samples collected from the Tracy Segment indicates that recharge processes do not match the steady-state model assumed by the chloride-balance approach. Specifically, seasonal precipitation, accumulation of dry deposition, ET, and intermittent streamflow infiltration probably result in multiple chloride spikes in these profiles. Profiles for sites 5, 7, and 10 (fig. 13) have maximum concentrations in samples nearest to land surface ( $<5 \mathrm{ft}$ ), suggesting that most soil moisture is removed from this depth, probably due to the combined effects of evaporation from bare soil and ET by shallow-rooted grasses, forbes, and shrubs. Sites 5, 6, and 8 all had chloride spikes near the 10 to $16 \mathrm{ft}$ depth range, which may correspond to the effective ET depth, although site 9 has its maximum chloride concentration at $24 \mathrm{ft}$.

Table 18 lists cumulative mass of chloride dissolved in unsaturated sediment, estimates of time required for that mass to accumulate, and average annual recharge rates. Site 10 has the least mass of accumulated chloride $\left(4,100 \mu \mathrm{g} / \mathrm{cm}^{2}\right)$, due to infiltration of streamflow discharged to this ephemeral channel during a 72-hr pumped-well aquifer test that has leached chloride below the profile. Site 8 has accumulated the most chloride $\left(52,000 \mu \mathrm{g} / \mathrm{cm}^{2}\right)$, based on 9 samples with more than $200 \mathrm{mg} / \mathrm{L}$ in a zone from 8 to $17 \mathrm{ft}$ below land surface. Site 5 (fig. 2) is the only site not located in an ephemeral channel and has the second largest chloride mass $\left(36,000 \mu \mathrm{g} / \mathrm{cm}^{2}\right)$ and the largest measured concentrations $(1,700 \mathrm{mg} / \mathrm{L})$ near land surface (table 17). Estimation of time needed to accumulate chloride in these profiles ranged from $400 \mathrm{yrs}$ at site 10 to $5,100 \mathrm{yrs}$ at site 8 . Average rates of annual recharge ranged from $0.0008 \mathrm{ft} / \mathrm{yr}$ (site 8 ) to $0.04 \mathrm{ft} / \mathrm{yr}$ (site 10).

\section{Water-Mass Balance}

Precipitation in the Tracy Segment during the 5-yr period spanning water years 1998-2002 was estimated to be 
Table 17. Chloride concentrations in pore-water extracts and selected physical characteristics of unsaturated-sediment samples collected from six test holes drilled in the Martin Canyon drainage basin, Tracy Segment Hydrographic Area, west-central Nevada

[Abbreviations: $\mathrm{mg} / \mathrm{L}$, micrograms per liter; $\mathrm{g} / \mathrm{cm}^{3}$, grams per cubic centimeter; $\mathrm{cm}^{3} / \mathrm{cm}^{3}$, cubic centimeter per cubic centimeter; $\mathrm{mg} / \mathrm{L}$, milligrams per liter; - , no measurement]

\begin{tabular}{|c|c|c|c|c|}
\hline $\begin{array}{l}\text { Depth below } \\
\text { land surface } \\
\text { (feet) }\end{array}$ & $\begin{array}{l}\text { Chloride mass } \\
\text { per mass of } \\
\text { dry sediment } \\
(\mathrm{mg} / \mathrm{g})\end{array}$ & $\begin{array}{c}\text { Bulk } \\
\text { density } \\
\left(\mathbf{g} / \mathrm{cm}^{3}\right)\end{array}$ & $\begin{array}{l}\text { Volumetric water } \\
\text { content } \\
\left(\mathrm{cm}^{3} / \mathrm{cm}^{3}\right)\end{array}$ & $\begin{array}{c}\text { Chloride } \\
\text { concentration } \\
\text { in pore water } \\
(\mathrm{mg} / \mathrm{L})\end{array}$ \\
\hline \multicolumn{5}{|c|}{ Site 5} \\
\hline $0.5-1.0$ & 120 & 1.41 & 0.1 & 1,700 \\
\hline प्राप्रा & 110 & 1.41 & 0.13 & 1,100 \\
\hline प्राप्रा & 1.1 & 1.41 & 0.24 & 9.3 \\
\hline प्राप्र & 0.94 & 1.41 & 0.3 & 5.4 \\
\hline प्राप & 37 & 1.41 & 0.31 & 360 \\
\hline QDij & 33 & 1.41 & 0.25 & 400 \\
\hline $\mathrm{ij}$ & 38 & 1.41 & 0.23 & 370 \\
\hline प्रा & 25 & 1.41 & 0.25 & 310 \\
\hline प्रा० & 24 & 1.41 & 0.26 & 290 \\
\hline परमा० & 29 & 1.41 & 0.24 & 380 \\
\hline पर००ण & 20 & 1.41 & 0.26 & 250 \\
\hline परमा० & 15 & 1.41 & 0.27 & 210 \\
\hline $13-14$ & 13 & 1.41 & 0.27 & 180 \\
\hline $14-15$ & 13 & 1.41 & 0.27 & 170 \\
\hline $15-16$ & 19 & 1.41 & 0.29 & 150 \\
\hline $16-17$ & 12 & 1.41 & 0.26 & 190 \\
\hline $17-18$ & 9.8 & 1.41 & 0.27 & 100 \\
\hline $18-19$ & 11 & 1.41 & 0.31 & 93 \\
\hline $19-20$ & 5.6 & 1.41 & 0.33 & 45 \\
\hline $20-21$ & 1.6 & 1.41 & 0.31 & 17 \\
\hline $21-22$ & 18 & 1.41 & 0.29 & 110 \\
\hline $22-23$ & 0.87 & 1.41 & 0.28 & 8.6 \\
\hline $23-24$ & 0.93 & 1.41 & 0.31 & 8.8 \\
\hline $24-25$ & 0.53 & 1.41 & 0.31 & 7.5 \\
\hline $\begin{array}{l}\text { Average chloride concentra- } \\
\text { tion for samples from } 10 \mathrm{ft} \\
\text { or deeper }(\mathrm{N}=15)\end{array}$ & 11 & 1.41 & 0.28 & \\
\hline \multicolumn{5}{|c|}{ Site 6} \\
\hline $1-2$ & 1.3 & 1.4 & 0.14 & 38 \\
\hline $4-5$ & 2.7 & 1.4 & 0.22 & 45 \\
\hline $5-6$ & 2.3 & 1.4 & 0.23 & 30 \\
\hline $6-7$ & 2.8 & 1.4 & 0.25 & 18 \\
\hline $7-8$ & 2.5 & 1.4 & 0.29 & 16 \\
\hline $8-9$ & 2.4 & 1.51 & 0.34 & 19 \\
\hline $10-11$ & 3.3 & 1.51 & 0.39 & 26 \\
\hline
\end{tabular}


Table 17. Chloride concentrations in pore-water extracts and selected physical characteristics of unsaturated-sediment samples collected from six test holes drilled in the Martin Canyon drainage basin, Tracy Segment Hydrographic Area, west-central Nevada-Continued

\begin{tabular}{|c|c|c|c|c|}
\hline $\begin{array}{l}\text { Depth below } \\
\text { land surface } \\
\text { (feet) }\end{array}$ & $\begin{array}{l}\text { Chloride mass } \\
\text { per mass of } \\
\text { dry sediment }{ }^{1} \\
(\mathrm{mg} / \mathrm{g})\end{array}$ & $\begin{array}{c}\text { Bulk } \\
\text { density } \\
\left(\mathbf{g} / \mathrm{cm}^{3}\right)\end{array}$ & $\begin{array}{c}\text { Volumetric water } \\
\text { content }^{3} \\
\left(\mathrm{~cm}^{3} / \mathrm{cm}^{3}\right)\end{array}$ & $\begin{array}{c}\text { Chloride } \\
\text { concentration } \\
\text { in pore water } \\
(\mathrm{mg} / \mathrm{L})\end{array}$ \\
\hline \multicolumn{5}{|c|}{ Site 6-Continued } \\
\hline $12-13$ & 4.2 & 1.51 & 0.3 & 57 \\
\hline $14-15$ & 2.3 & 1.51 & 0.29 & 29 \\
\hline $16-17$ & 1.6 & 1.9 & 0.29 & 20 \\
\hline $17-18$ & 1.9 & 1.9 & 0.28 & 24 \\
\hline $18-19$ & 1.2 & 1.9 & 0.29 & 6.6 \\
\hline $24-25$ & 3.4 & 1.9 & 0.29 & 36 \\
\hline $\begin{array}{l}\text { Average chloride concentra- } \\
\text { tion for samples from } 10 \mathrm{ft} \\
\text { or deeper }(\mathrm{N}=7)\end{array}$ & 2.6 & 1.73 & 0.33 & 28 \\
\hline
\end{tabular}

\begin{tabular}{|c|c|c|c|c|}
\hline \multicolumn{5}{|c|}{ Site 7} \\
\hline $1-2$ & 11 & 1.34 & 0.11 & 220 \\
\hline $2-3$ & 2.2 & 1.34 & 0.14 & 66 \\
\hline $3-4$ & 1.9 & 1.34 & 0.15 & 64 \\
\hline $4-5$ & 1.5 & 1.34 & 0.16 & 40 \\
\hline $5-6$ & 0.9 & 1.34 & 0.22 & 22 \\
\hline $6-7$ & 1.1 & 1.34 & 0.27 & 17 \\
\hline $7-8$ & 1.7 & 1.34 & 0.26 & 15 \\
\hline $8-9$ & 1.9 & 1.34 & 0.25 & 17 \\
\hline $9-10$ & 2.8 & 1.34 & 0.27 & 23 \\
\hline $10-11$ & 2.4 & 1.34 & 0.3 & 27 \\
\hline $12-13$ & 4.5 & 1.34 & 0.29 & 27 \\
\hline $13-14$ & 4.8 & 1.34 & 0.37 & 30 \\
\hline $14-15$ & 5 & 1.34 & 0.39 & 30 \\
\hline $15-16$ & 7.7 & 1.34 & 0.4 & 36 \\
\hline $18-19$ & 6.9 & 1.34 & 0.4 & 26 \\
\hline $19-20$ & 7.7 & 1.34 & 0.43 & 32 \\
\hline $20-21$ & 7 & 1.34 & 0.41 & 28 \\
\hline $22-23$ & 6.2 & 0.61 & 0.42 & 9.5 \\
\hline $\begin{array}{l}\text { Average chloride concentra- } \\
\text { tion for samples from } 10 \mathrm{ft} \\
\text { or deeper }(\mathrm{N}=9)\end{array}$ & 5.8 & 1.26 & 0.38 & 27 \\
\hline \multicolumn{5}{|c|}{ Site 8} \\
\hline $0-1$ & 3.3 & 1.39 & -- & 160 \\
\hline $1-2$ & 4 & 1.39 & 0.09 & 420 \\
\hline $4-5$ & 1.4 & 1.39 & 0.2 & 34 \\
\hline $5-6$ & 3.2 & 1.39 & 0.19 & 66 \\
\hline $6-7$ & 3.5 & 1.39 & 0.22 & 74 \\
\hline $7-8$ & 9.8 & 1.39 & 0.2 & 250 \\
\hline
\end{tabular}


Table 17. Chloride concentrations in pore-water extracts and selected physical characteristics of unsaturated-sediment samples collected from six test holes drilled in the Martin Canyon drainage basin, Tracy Segment Hydrographic Area, west-central Nevada-Continued

\begin{tabular}{|c|c|c|c|c|}
\hline $\begin{array}{l}\text { Depth below } \\
\text { land surface } \\
\text { (feet) }\end{array}$ & $\begin{array}{l}\text { Chloride mass } \\
\text { per mass of } \\
\text { dry sediment }{ }^{1} \\
(\mathrm{mg} / \mathrm{g})\end{array}$ & $\begin{array}{c}\text { Bulk } \\
\text { density }^{2} \\
\left(\mathrm{~g} / \mathrm{cm}^{3}\right)\end{array}$ & $\begin{array}{c}\text { Volumetric water } \\
\text { content }^{3} \\
\left(\mathrm{~cm}^{3} / \mathbf{c m}^{3}\right)\end{array}$ & $\begin{array}{c}\text { Chloride } \\
\text { concentration } \\
\text { in pore water } \\
(\mathrm{mg} / \mathrm{L})\end{array}$ \\
\hline \multicolumn{5}{|c|}{ Site 8-Continued } \\
\hline $8-9$ & 30 & 1.39 & 0.21 & 550 \\
\hline $10-11$ & 24 & 1.39 & 0.24 & 730 \\
\hline $11-12$ & 41 & 1.39 & 0.25 & 560 \\
\hline $12-13$ & 45 & 1.39 & 0.28 & 460 \\
\hline $13-14$ & 36 & 1.39 & 0.29 & 410 \\
\hline $14-15$ & 23 & 1.39 & 0.29 & 310 \\
\hline $15-16$ & 21 & 1.39 & 0.27 & 290 \\
\hline $16-17$ & 18 & 1.39 & 0.29 & 240 \\
\hline $17-18$ & 27 & 1.39 & 0.29 & 190 \\
\hline $18-19$ & 30 & 1.39 & 0.39 & 170 \\
\hline $19-20$ & 29 & 1.39 & 0.36 & 200 \\
\hline $21-22$ & 22 & 1.39 & 0.34 & 180 \\
\hline $22-23$ & 21 & 1.39 & 0.34 & 170 \\
\hline $23-24$ & 16 & 1.39 & 0.37 & 130 \\
\hline $24-25$ & 16 & 1.39 & 0.37 & 140 \\
\hline $25-26$ & 14 & 1.39 & 0.37 & 120 \\
\hline $\begin{array}{l}\text { Average chloride concentra- } \\
\text { tion for samples from } 10 \mathrm{ft} \\
\text { or deeper }(\mathrm{N}=15)\end{array}$ & 26 & 1.39 & 0.32 & 290 \\
\hline
\end{tabular}

or deeper $(\mathrm{N}=15)$

\begin{tabular}{|c|c|c|c|c|}
\hline $2-3$ & 1.5 & 1.47 & 0.16 & 44 \\
\hline $3-4$ & 1.3 & 1.47 & 0.17 & 17 \\
\hline $4-5$ & 2.4 & 1.47 & 0.2 & 1 \\
\hline $5-6$ & 2.4 & 1.47 & 0.24 & \\
\hline $9-10$ & 3.8 & 1.47 & 0.47 & \\
\hline $10-11$ & 4.8 & 1.47 & 0.48 & 40 \\
\hline $11-12$ & 3.5 & 1.47 & 0.39 & \\
\hline $12-13$ & 2.8 & 1.47 & 0.31 & 1 \\
\hline $13-14$ & 2.7 & 1.47 & 0.26 & 5 \\
\hline $14-15$ & 3.2 & 1.47 & 0.34 & \\
\hline $15-16$ & 2.6 & 1.47 & 0.36 & \\
\hline $16-17$ & 3.1 & 1.47 & 0.35 & \\
\hline $17-18$ & 3.5 & 1.47 & 0.35 & \\
\hline $18-19$ & 3.8 & 1.47 & 0.34 & \\
\hline $19-20$ & 1.9 & 1.47 & 0.34 & \\
\hline $20-21$ & 6.8 & 1.47 & 0.35 & \\
\hline $21-22$ & 5.6 & 1.47 & 0.34 & \\
\hline $22-23$ & 5.8 & 1.47 & 0.33 & \\
\hline
\end{tabular}


Table 17. Chloride concentrations in pore-water extracts and selected physical characteristics of unsaturated-sediment samples collected from six test holes drilled in the Martin Canyon drainage basin, Tracy Segment Hydrographic Area, west-central Nevada-Continued

\begin{tabular}{|c|c|c|c|c|}
\hline $\begin{array}{l}\text { Depth below } \\
\text { land surface } \\
\quad \text { (feet) }\end{array}$ & $\begin{array}{c}\text { Chloride mass } \\
\text { per mass of } \\
\text { dry sediment }{ }^{1} \\
(\mathrm{mg} / \mathrm{g})\end{array}$ & $\begin{array}{c}\text { Bulk } \\
\text { density } \\
\left(\mathbf{g} / \mathbf{c m}^{3}\right)\end{array}$ & $\begin{array}{c}\text { Volumetric water } \\
\text { content }^{3} \\
\left(\mathrm{~cm}^{3} / \mathrm{cm}^{3}\right)\end{array}$ & $\begin{array}{c}\text { Chloride } \\
\text { concentration } \\
\text { in pore water } \\
\text { (mg/L) }\end{array}$ \\
\hline \multicolumn{5}{|c|}{ Site 9} \\
\hline $23-24$ & 6.5 & 1.47 & 0.35 & 82 \\
\hline $\begin{array}{l}\text { Average chloride concentra- } \\
\text { tion for samples from } 10 \mathrm{ft} \\
\text { or deeper }(\mathrm{N}=14)\end{array}$ & 4 & 1.47 & 0.35 & 48 \\
\hline \multicolumn{5}{|c|}{ Site 10} \\
\hline $2-3$ & 1.6 & 1.39 & 0.39 & 36 \\
\hline $6-7$ & 4.9 & 1.39 & 0.48 & 16 \\
\hline $10-11$ & 1.9 & 0.97 & 0.42 & 4.7 \\
\hline $11-12$ & 5 & 0.97 & 0.48 & 17 \\
\hline $12-13$ & 2.1 & 1.39 & 0.44 & 6.5 \\
\hline $15-16$ & 2.4 & 1.39 & 0.6 & 6.3 \\
\hline $17-18$ & 1.6 & 1.39 & 0.49 & 7.5 \\
\hline $18-19$ & 2.3 & 1.39 & 0.52 & 8.8 \\
\hline $20-21$ & 2.6 & 1.39 & 0.5 & 8 \\
\hline $21-22$ & 1.6 & 1.39 & 0.47 & 8.2 \\
\hline $23-24$ & 2.4 & 1.39 & 0.44 & 10 \\
\hline $\begin{array}{l}\text { Average chloride concentra- } \\
\text { tion for samples from } 10 \mathrm{ft} \\
\text { or deeper }(\mathrm{N}=9)\end{array}$ & 2.4 & 1.3 & 0.48 & 8.6 \\
\hline
\end{tabular}

${ }^{1}$ Mass of chloride per unit mass of sediment determined by ion chromatography of one-to-one by mass, deionized water extraction (Katherine C. Akstin, U.S. Geological Survey, written commun., 2002) and rounded to two significant figures.

${ }^{2}$ Values based on 20 measurements in 5 test holes (site 5, one, depth 0-1 foot; site 6, nine from depths of 7.3-7.8, 7.8-8.3, 8.3-8.8, 8.8-9.3, 9.3-9.6, 16-16.5, 17-17.5 and 17.5-17.8 feet; site 7, five from depths of 16-16.5, 16.5-17, 17-17.5, 17.5-18, 22-22.5 and 23-23.5 feet; site 9, three from depths of 7-7.5, 7.5-8, and 8-9 feet; and site 10, two from depths of 9.5-10 and 10-10.5 feet).

${ }^{3}$ Values based on (1) the product of gravimetric water content and bulk density determined on 20 core samples sealed with tape upon collection, weighed in the laboratory, oven dried, and reweighed and (2) neutron-moisture probe calibrated by linear regression [volumetric water content $=0.05+$ $\left(0.377 \mathrm{x}\right.$ (neutron counts/shielded count)) coefficient of determination, $\left.\mathrm{R}^{2}=0.48\right]$ with volumetric water content of 20 cores.

${ }^{4}$ Rounded to two significant figures. 
Site 5

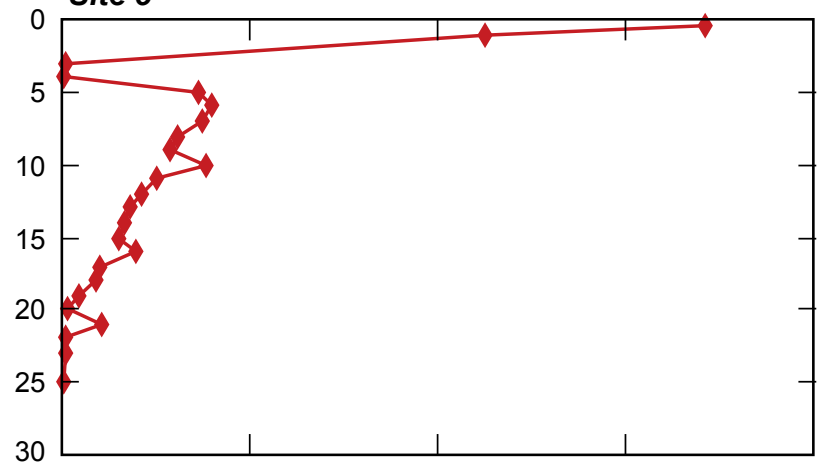

Site 7
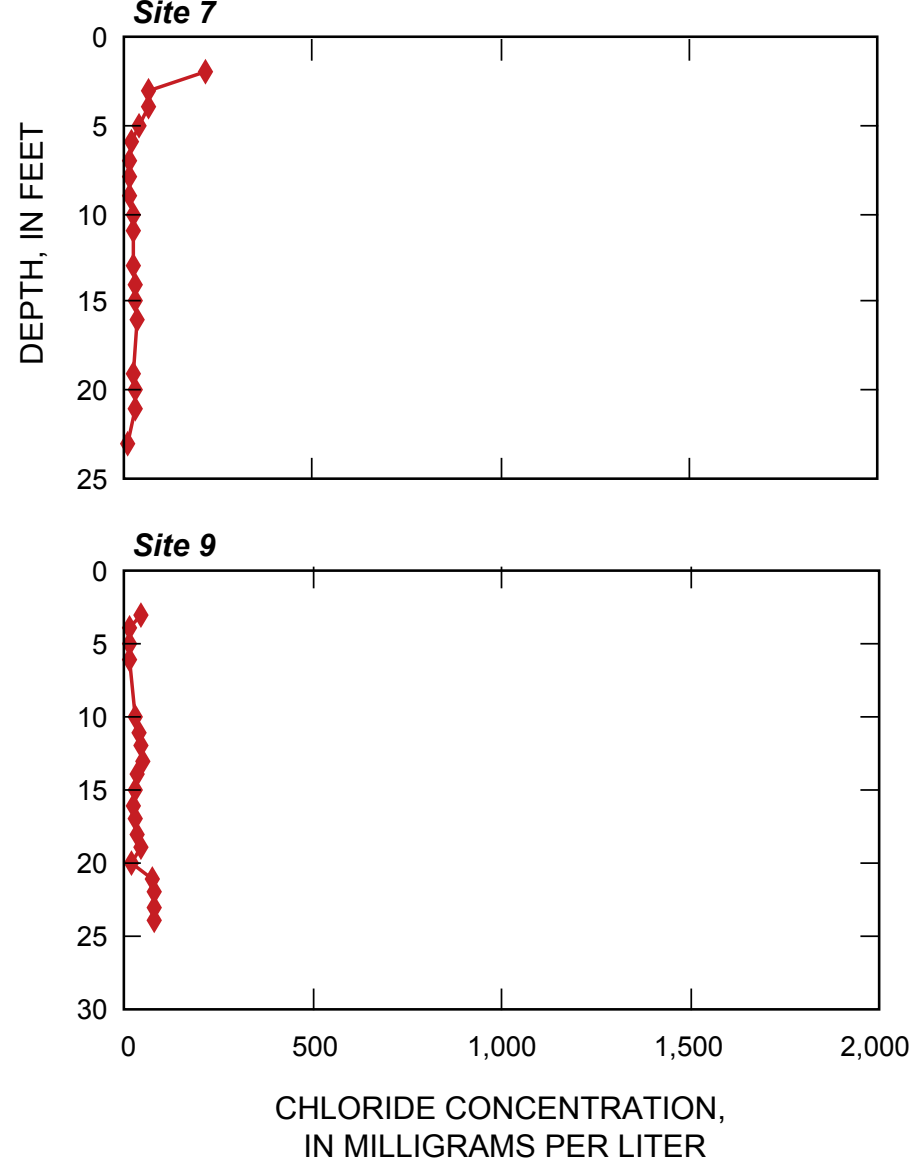

Site 6

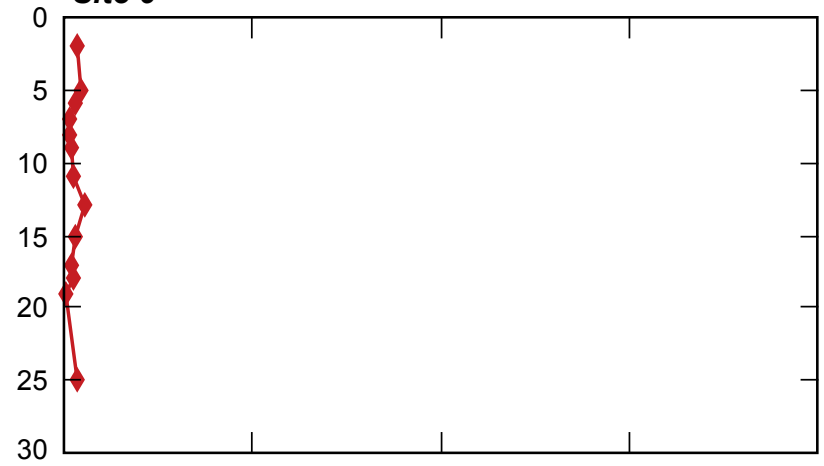

Site 8

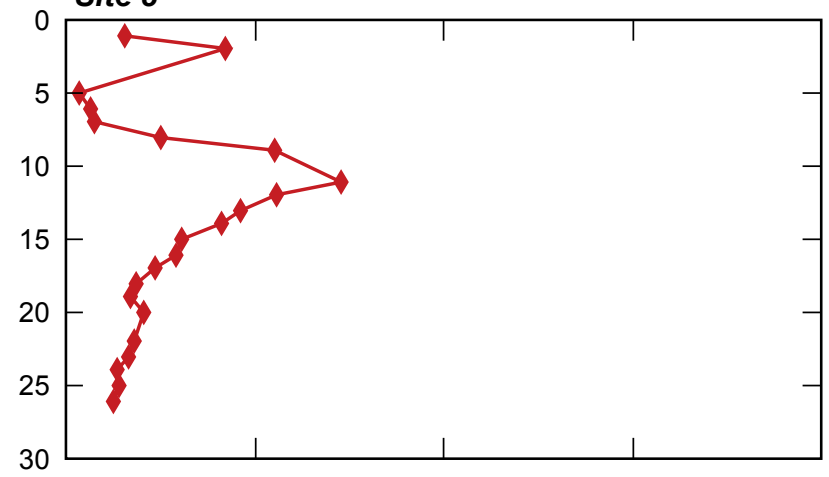

Site 10

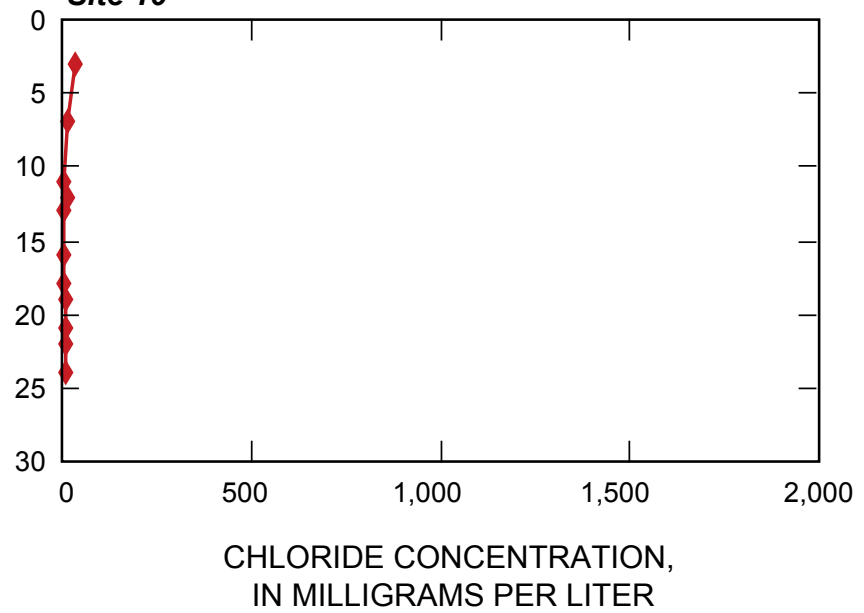

Figure 13. Chloride concentrations in pore water of unsaturated sediment, at selected sites in the Martin Canyon drainage basin, Tracy Segment Hydrographic Area, west-central Nevada. 
Table 18. Cumulative mass of chloride in pore water in unsaturated sediment samples, and chloride-age and average annual recharge rates estimated by chloride-mass balance, Tracy Segment Hydrographic Area, west-central Nevada

[Abbreviations: $\mu \mathrm{g} / \mathrm{cm}^{2}$, micrograms per square centimeter]

\begin{tabular}{ccccc}
\hline Site & Cumulative & Estimated & & \multicolumn{2}{c}{$\begin{array}{c}\text { Estimated average annual recharge rate } \\
\text { (fig. 2) }\end{array}$} & $\begin{array}{c}\text { (feet) } \\
\text { chloride } \\
\text { chloride age } \\
\text { (years) }\end{array}$ & $\begin{array}{c}\text { Samples from } \\
\mathbf{1 0 - 2 3} \text { feet }\end{array}$ & $\begin{array}{c}\text { Samples from } \\
\mathbf{1 6 - 2 3} \text { feet }\end{array}$ \\
\hline 5 & 36,000 & 3,500 & .003 & .005 \\
6 & 7,000 & 700 & .01 & .02 \\
7 & 7,600 & 750 & .01 & .01 \\
8 & 52,000 & 5,100 & .0008 & .002 \\
9 & 9,600 & 860 & .007 & .006 \\
10 & 4,100 & 400 & .04 & .04 \\
\hline
\end{tabular}

130,000-174,000 acre-ft/yr (see section Annual Precipitation). ET from recharge areas in the Tracy Segment is estimated to be 124,000-158,000 acre-ft/yr (see section Evapotranspiration). Ephemeral runoff to the Truckee River is estimated to be 5,000 acre-ft/yr (see section Ephemeral Streams). Changes in storage in unsaturated sediments above aquifers are considered qualitatively (fig. 14) to be negligible due to minimal measured changes in moisture at depths beneath the effective root zone (more than $10 \mathrm{ft}$ ). Gravimetric moisture content of the 20 core samples averaged 30 percent and ranged from 2 to 67 percent by weight. Bulk density averaged $1.39 \mathrm{~g} / \mathrm{cm}^{3}$ and ranged from 0.54 to $2.42 \mathrm{~g} / \mathrm{cm}^{3}$. Moisture content of each borehole was logged with the neutron probe 9 times from June 2001 through September 2002 (fig. 14). Initial volumetric moisture content measured by using a neutron probe June 13 and 14, 2001, at 138 measurement depths in the 6 boreholes ranged from 0.09 to $0.60 \mathrm{~cm}^{3} / \mathrm{cm}^{3}$ with an average value of 0.32 . Moisture content measured $1 \mathrm{ft}$ below land surface in each borehole showed the greatest response to precipitation during November through January 2001, when 6.9 in. of precipitation from 19 storms was reported by the National Weather Service station near Virginia City. Moisture content at $1 \mathrm{ft}$ also was lowest prior to the series of storm events. Moisture-content response at greater depths was subtle; however, measurements indicate that moisture content increased as deep as $22 \mathrm{ft}$ below land surface. Measured moisture content of unsaturated sediments at depths less than $8 \mathrm{ft}$ subsequently returned to near-initial moisture content due to ET and deep percolation. The largest moisture contents were measured in cores collected from site 10 which is located in an ephemeral channel that received ground water from a pumped-well aquifer test on April 24, 2001. The smallest bulk density values were for cores containing diatomite.

Applying these values of precipitation, ET, and runoff to equation 3 , and assuming that $\Delta \mathrm{S}$ is negligible, results in recharge estimates of 2,000 to 22,000 acre-ft/yr. The largest estimate was primarily due to more precipitation estimated by the 1997 precipitation map, which overestimates precipitation reported at precipitation stations in and near the Tracy Seg- ment and normalized to 1971-2000 (table 3). Chloride-balance estimates support recharge from precipitation in the range 1,000 to 10,000 acre-ft/yr and that ET consumes most precipitation at altitudes less than 5,000 ft.

\section{Recharge from Intermittent Streamflow}

Factors that influence the volume of recharge which result from intermittent streamflow include frequency and duration of runoff events, consumption of infiltrated moisture by ET, and the permeability and wetted area of ephemeral channels. Streamflow was estimated to occur one to five times each year along most ephemeral channels in the Tracy Segment. Linear regression of precipitation data from the National Weather Service precipitation station near Virginia City and peak discharge data from the CSG at Long Valley Creek (table 9) indicate that 10-day cumulative precipitation (the amount of precipitation to accumulate over the 10 days prior to, and including the day of reported runoff) explained 58 percent of peak discharge variability $\left(\mathrm{R}^{2}=0.58\right.$; fig. 15$)$. The median 10 day cumulative precipitation value associated with runoff is 1.34 in., which is about 35 percent of the 10 -day precipitation estimate for a 2-year average recurrence interval near Virginia City and 70 percent of 10-day precipitation estimated near Wadsworth (Bonnin and others, 2004). Most of the peak flows recorded at the CSG occurred during winter months when precipitation accumulated and subsequently melted to contribute to streamflow.

Temperature-profile data used as markers of intermittent streamflow in Martin Canyon (site 11) and in Long Valley Creek (site 12; fig. 2), along with daily precipitation data from the National Weather Service station near Virginia City, are shown in figure 16. During operation of temperature-profile installations, 44 days showed precipitation was reported for the National Weather Service station near Virginia City, which ranged from less than 0.01 to $1.4 \mathrm{in}$. and accumulated to 11.9 in. These days of precipitation fall into 21 groups of 10-day cumulative precipitation values which ranged from less than 0.01 to 2.0 in., most during November through April. Visual 

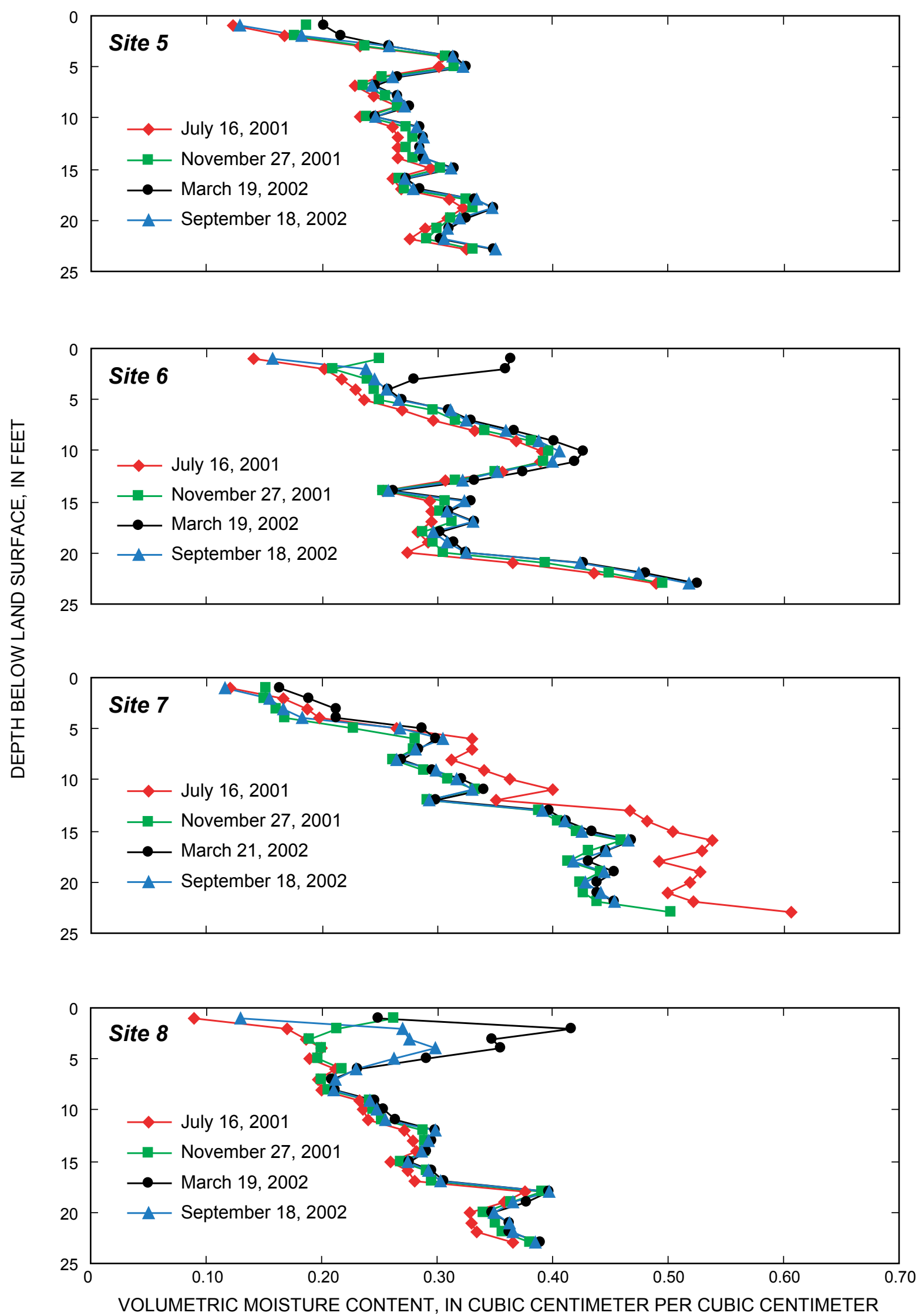

Figure 14. Changes in volumetric moisture content in unsaturated sediments at selected depths at selected sites in the Martin Canyon drainage basin, June 2001 through September 2002, Tracy Segment Hydrographic Area, west-central Nevada. 


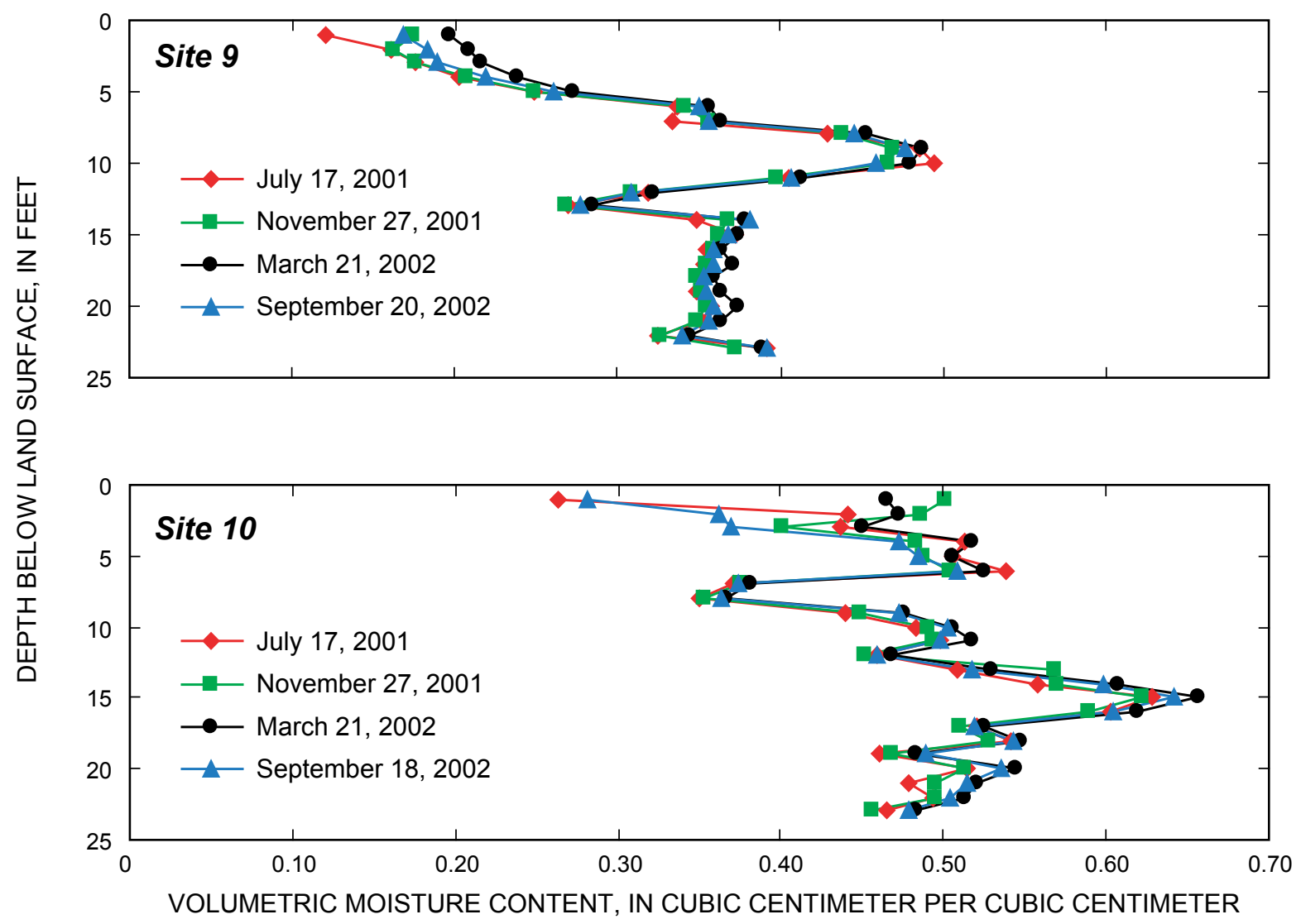

Figure 14. Changes in volumetric moisture content in unsaturated sediments at selected depths at selected sites in the Martin Canyon drainage basin, June 2001 through September 2002, Tracy Segment Hydrographic Area, west-central Nevada-Continued.

inspection of temperature data (fig. 16) indicates that precipitation or streamflow infiltrated $3 \mathrm{ft}$ beneath the streambed on 10 occasions.

Duration of individual intermittent-streamflow events was estimated to last between 5 and 48 hours, depending on the type of runoff event and location of channel reach within the drainage basin. Summer thunderstorms typically generate short-term localized streamflow, whereas winter storms are more regional and may accumulate and store water as snow that is available to sustain streamflow as it melts. Warm winter storms, especially ones that follow snowstorms, are widely acknowledged to cause severe flooding attributed to "rain on snow events." The largest peak discharge $\left(5,400 \mathrm{ft}^{3} / \mathrm{s}\right)$ recorded at the CSG on Long Valley Creek was measured on February 19, 1986, when flooding affected Carson City and Douglas, Lyon, Storey, and Washoe Counties and increased precipitation from 75 percent of average on February 1, 1986, to about 150 percent of average on March 1, 1986, (James, 1986). Streamflow of $290 \mathrm{ft}^{3} / \mathrm{s}$ at the CSG was measured the following day (U.S. Geological Survey, written commun., 1986).

All peak-discharge events except three were recorded during December through March and the three events recorded in May, June, and August were less than $50 \mathrm{ft}^{3} / \mathrm{s}$ (table 9). One streamflow event was recorded in response to summer storms measured at the Reno Airport on August 1 and 2, 2002. Precipitation was not recorded at the weather station near Virginia City, but thermocouples recorded temperature responses at both Long Valley Creek and Martin Canyon and high water marks were surveyed on Martin Canyon that indicate a peak discharge of about $40 \mathrm{ft}^{3} / \mathrm{s}$. Temperature data indicate flow during this runoff event lasted about 16 hours.

Estimated consumption of infiltrated streamflow by ET was $0.1 \mathrm{ft}$ based on micrometeorological data and the assumption that part of the infiltrated moisture will be held within the effective root zone for 10 days. Measured rates of ET ranged from less than 0.001 to $0.154 \mathrm{in} / \mathrm{d}$ (table 6 ), but vegetation is more abundant along ephemeral channels because of increased availability of soil moisture.

Permeability of ephemeral channels in the Tracy Segment was estimated to range from 0.1 to $12 \mathrm{ft} / \mathrm{d}$. Permeability of soils associated with ephemeral streambeds was reported to range from 0.04 to $40 \mathrm{ft} / \mathrm{d}$, with 4 to $12 \mathrm{ft} / \mathrm{d}$ reported most frequently (Archer, 1990, p. 261-270; Baumer, 1983, p. 547-575). Permeability along a 3,000-ft reach of Long Valley Creek that receives ground water from several springs was estimated on November 11, 2001. About $0.05 \mathrm{ft}^{3} / \mathrm{s}$ of streamflow was measured at the upper-most cross section of the stream using 


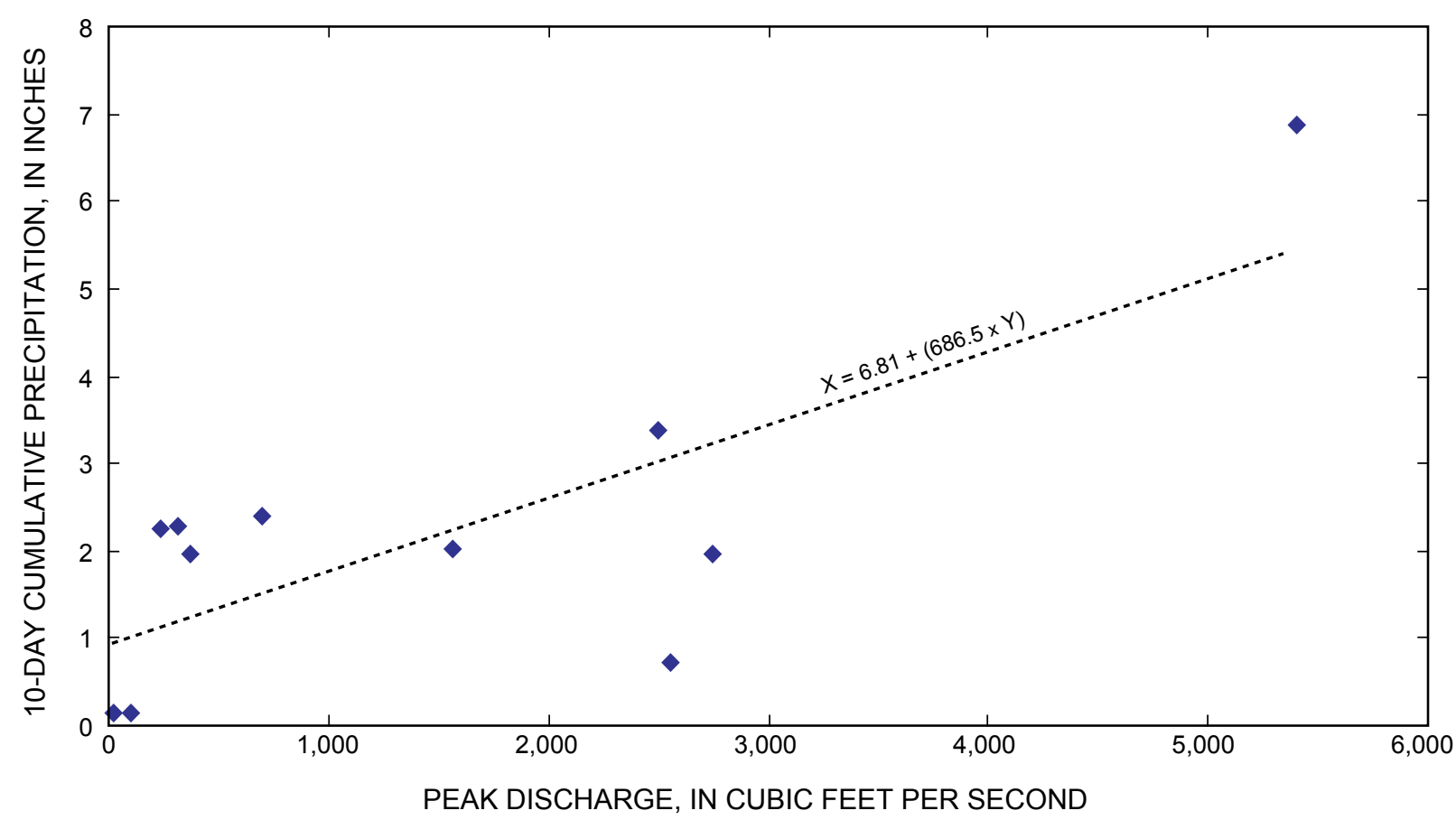

Figure 15. Relation of precipitation reported for National Weather Service station near Virginia City and maximum discharge recorded at crest-stage station on Long Valley Creek near Lockwood, Tracy Segment Hydrographic Area, west-central Nevada.

a 3-in. modified Parshall flume. Streamflow had completely infiltrated 3,000 ft downstream of the first cross section. About $12,000 \mathrm{ft}^{2}$ of wetted streambed was estimated by measuring cross-sectional widths at 30 locations along the reach and an infiltration rate of $0.36 \mathrm{ft} / \mathrm{d}$ was computed. The time required for recorded temperature response to streamflow at $0.3 \mathrm{ft}$ beneath ephemeral streambeds to be recorded at probes at 3.3 $\mathrm{ft}$ (site 11) and $3.6 \mathrm{ft}$ (site 12) indicate infiltration rates ranged from about 2.4 to $7.2 \mathrm{ft} / \mathrm{d}$ and 7.9 to $16 \mathrm{ft} / \mathrm{d}$, respectively.

The area of ephemeral channels in the Tracy Segment is estimated to range from 100 to 500 acres using a length of 390 mi estimated from digital elevation models (U.S. Geological Survey, 2002) and an average channel width that ranged from 2 to $10 \mathrm{ft}$. Digital elevation models used in this analysis have elevation values reported to the nearest $0.1 \mathrm{ft}$ that are distributed over a $100-\mathrm{ft}$ grid. Ephemeral channels located in the headwaters of the drainage basin have a greater drainage-network density, but individual channels are smaller than channels located further downstream.

Assuming intermittent runoff occurs 3 times a year, lasts for 1 day, and wetted ephemeral streambeds cover 200 acres with streambed permeability of $1.5 \mathrm{ft} /$ day, recharge from intermittent streamflow was estimated to average about 1,000 acre-ft/yr, but may range from 2 to 6,000 acre-ft/yr in any given year.

\section{Recharge from Truckee River Water}

In the Tracy Segment, streamflow at gaging stations along the Truckee River (table 7) indicate dynamic interaction between streamflow and ground water, with a net gain of 11,000 acre-ft/yr from ground water in the Tracy Segment. However, between the streamflow-gaging station near Tracy (site 14) and below Derby Dam (sites 15 and 16), the river loses 62,000 acre-ft/yr and water-level altitudes in wells south of Patrick and Tracy (fig. 8) are lower than the altitude of the river. Seepage loss of water diverted from the Truckee River into the Truckee Canal for agricultural use was estimated by application of a previously developed linear regression (VanDenburgh and Arteaga, 1985) to be 9,300 acre-ft/yr.

Estimates of the percentage of irrigation water applied to crops in northern Nevada that may recharge ground water range from 16 percent in the Stagecoach subbasin of the Carson River hydrographic region (Harrill and Preissler, 1994, p. H41) to 40 percent of irrigation water applied to crops in the Paradise Valley HA of the Humboldt River hydrographic region (Harrill and Moore, 1970, p. 70). About 7,700 acre$\mathrm{ft} / \mathrm{yr}$ was diverted from the Truckee River to irrigate 940 acres of pastures and alfalfa (Federal Water Master, written commun., 2003) and, assuming that estimates of crop water-use are reasonable for agricultural practices in the Tracy Segment, 1,000 to 3,000 acre- $\mathrm{ft}$ of irrigation water may recharge ground water in average years. An estimated 10,000 to 13,000 acre$\mathrm{ft} / \mathrm{yr}$ of Truckee River irrigation water recharges ground water. Except for ground-water drainage away from the river through 


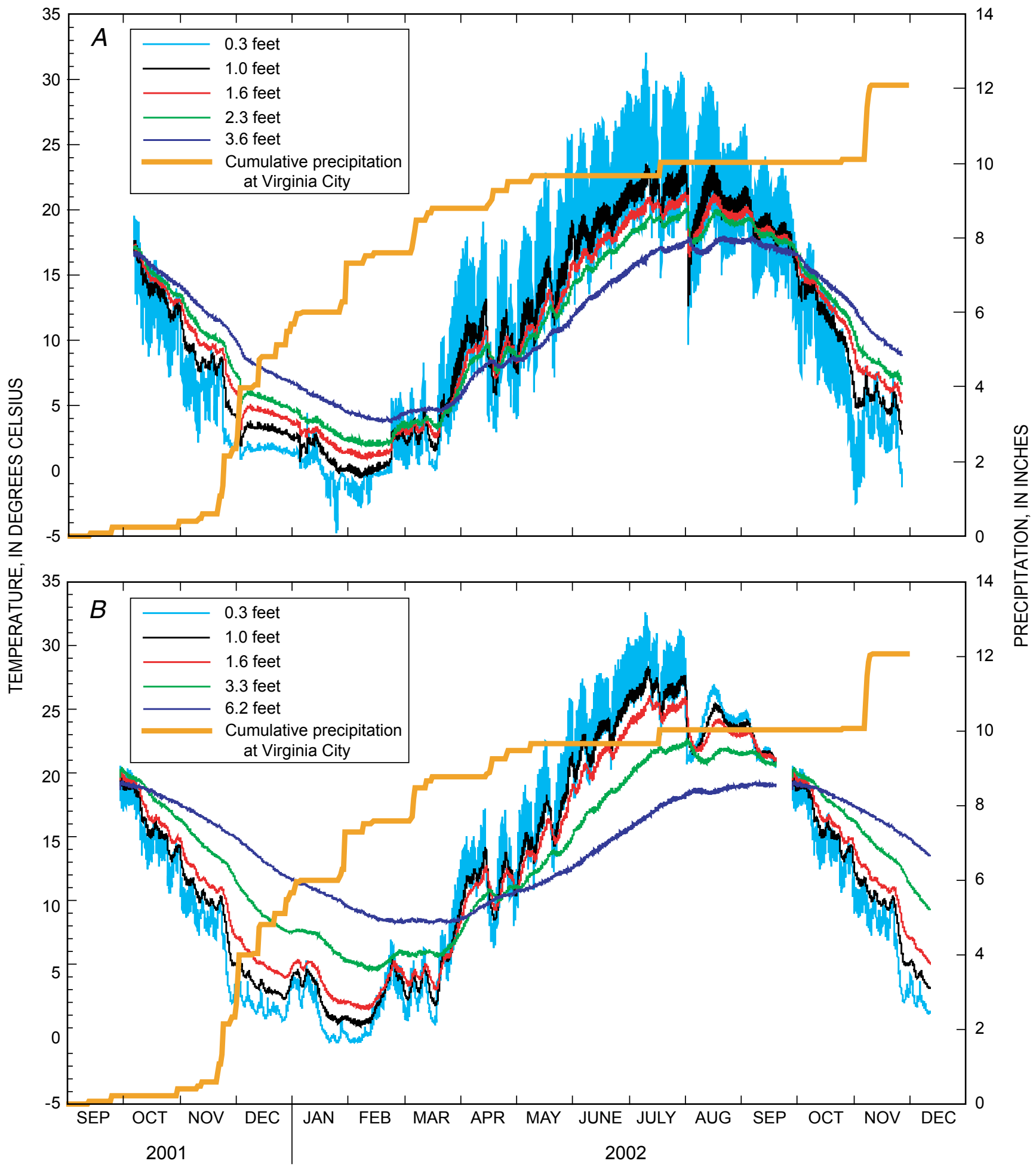

Figure 16. Hourly subsurface temperature recorded beneath intermittent stream channels in A, Long Valley Canyon and B, Martin Canyon, Tracy Segment Hydrographic Area, and cumulative precipitation recorded at Virginia City, west-central Nevada. 
permeable fracture- and fault-zones, ground-water recharge from Truckee River water is confined to the alluvial aquifer beneath the Truckee River flood plain. Isotopic composition of ground-water samples collected from wells completed in basin-fill deposits near the river indicate that these samples are comprised of 11-94 percent river water (table 15).

\section{Estimation of Secondary Recharge}

Infiltration from septic systems and cooling ponds recharges less than 700 acre-ft/yr. Assuming secondary recharge rates of $0.15 \mathrm{acre}-\mathrm{ft} / \mathrm{yr} /$ household (Maurer, 1997, p. 25 ), the approximately 300 septic systems for residences and businesses would have recharged about $50 \mathrm{acre}-\mathrm{ft} / \mathrm{yr}$. About 580 acre-ft/yr infiltrate from an unlined cooling pond at the Tracy Power Station of which $180 \mathrm{acre-ft/yr}$ was estimated to discharge to the river as ground-water seepage (Sierra Pacific Power Company and Ebasco Environmental, 1993, p. 4-3 through 4-4), leaving about $400 \mathrm{acre-ft/yr}$ available for ground-water recharge.

\section{Discharge}

A total of 8,000 acre-ft/yr of ground water was reported to be pumped from wells in the Tracy Segment (table 19; Mark Beutner, Nevada Division of Water Resources, written commun., 2000); however, most domestic wells were not included in this estimate. Domestic pumpage was estimated by counting houses within the Tracy Segment using digital aerial orthophotographs taken in 1994 and assuming an average rate of $0.5 \mathrm{acre}-\mathrm{ft} / \mathrm{yr} /$ household (Maurer, 1997, p. 25). Houses in areas where community water supplies are available were not counted. Inspection of this imagery indicates about 250 residential structures existed in the Tracy Segment in 1994 and domestic water-use is estimated to total less than $200 \mathrm{acre}-\mathrm{ft} /$ yr. Total ground-water pumpage in the Tracy Segment is estimated to be about 8,200 acre-ft/yr (table 19), of which about 51 percent was for municipal use, 21 percent for industrial use, 11 percent for mining and milling, 8 percent for irrigation, and 6 percent for commercial use. Ground-water withdrawals for stock-water and domestic-water use accounted for less than three percent of the total.

Consumptive water-use by phreatophytes and crops in the Tracy Segment was estimated to total 4,200 acre-ft/yr (table 19). Estimated rates of ET by phreatophytes and associated bare soil in the Great Basin ranged from 0.2 (Harrill and Preissler, 1994, p. H18) to $0.8 \mathrm{ft} / \mathrm{yr}$ (Nichols, 1994, p. 3272) depending on depth to water and canopy density. In the Tracy Segment, water-table depths less than $50 \mathrm{ft}$ are confined to about 8,000 acres along the Truckee River corridor. Applying an average ET rate of $0.4 \mathrm{ft} / \mathrm{yr}$ to 8,000 acres of phreatophytes yields 3,000 acre-ft/yr of ground-water discharge. Rates of transpiration from a riparian forest of cottonwood and willow in southeastern Arizona were estimated to be $0.016 \mathrm{ft} / \mathrm{d}$ using the heat-pulse velocity technique to measure sap flux (Schaef-
Table 19. Estimates of ground-water discharge, Tracy Segment Hydrographic Area, west-central Nevada

\begin{tabular}{cc}
$\begin{array}{c}\text { Mechanism of } \\
\text { ground-water } \\
\text { discharge }\end{array}$ & $\begin{array}{c}\text { Total withdrawals } \\
\text { (acre-feet per year) }\end{array}$ \\
\hline Total pumpage & 8,200 \\
Commercial pumpage & ${ }^{1500}$ \\
Domestic pumpage & ${ }^{2} 200$ \\
Industrial pumpage & ${ }^{1} 1,700$ \\
Irrigation pumpage & ${ }^{1} 660$ \\
Mining and milling pumpage & ${ }^{1} 880$ \\
Quasi-municipal pumpage & 14,200 \\
Stock pumpage & 130 \\
Phreatophytic evapotranspiration & 4,200 \\
Crops, desert shrubs, and bare soil & 3,200 \\
Cottonwood and willow shrubs & 1,000 \\
Total (rounded) & $\mathbf{1 2 , 0 0 0}$ \\
\hline
\end{tabular}

\footnotetext{
${ }^{1}$ Data from Nevada Division of Water Resources (Mark Beutner, written commun., 2000).

${ }^{2}$ Estimated by house count from aerial photography taken in 1994 for areas outside quasi-municipal delivery system boundaries.
}

fer and others, 2000, p. 265). Assuming 200 days of active transpiration, ground-water discharge from the 400 acres of cottonwood and willows (table 4) results in about 1,000 acre$\mathrm{ft} / \mathrm{yr}$ of ground-water discharge.

\section{Subsurface Inflow and Outflow}

Estimates of subsurface inflow and outflow were made using Darcy's Law (Heath, 1983, p. 12) and are based on estimates of transmissivity, hydraulic gradient, and width of the basin-fill and bedrock aquifers. An estimated 3,200 acre$\mathrm{ft} / \mathrm{yr}$ of ground water enters the Tracy Segment, with about 3,000 acre-ft/yr from the Fernley Area HA (fig. 1; VanDenburgh and Arteaga, 1985, p. 11). Subsurface inflow from the Truckee Meadows HA through bedrock hydrogeologic units was assumed negligible in earlier analysis (VanDenburgh and others, 1973). However, inflows from the Truckee Meadows HA may total 200 acre-ft/yr based on the mean transmissivity $\left(3,800 \mathrm{ft}^{2} / \mathrm{d}\right.$; table 2), the width of the Truckee River canyon where it crosses the hydrographic boundary $(1,000 \mathrm{ft})$, and the average slope reported for the riverbed $(0.005$; Brown and others, 1986, p. 107).

Ground-water outflow from the Tracy Segment to Dodge Flat HA (fig. 1) is estimated to total 2,500 acre-ft/yr based on an average hydraulic gradient of 0.006 between sites 52 and 53 (fig. 2), mean transmissivity of 3,800 ft' $/$ d, and aquifer width of 13,200 ft, but may range from 300 to 7,000 acre-ft/yr using transmissivity values from individual pump tests (table 2). Subsurface outflow was previously estimated to be 700 acre-ft/yr by VanDenburgh and others $(1973$, p. 44) and 3,600 acre-ft/yr by PTI Environmental Services (1997). 


\section{Estimated Water Budget}

Components of a water budget estimated for this study, using 1998 through 2002 hydrologic data, are summarized in table 20, including estimates of a ground-water budget. Estimated total inflow to the Tracy Segment (including meanannual precipitation and Truckee River streamflow at site 13 and adjusted to 1998-2002) ranged from 748,000 to 791,000 acre-ft/yr and total outflow (including non-phreatophytic ET) was 760,000-793,000 acre-ft/yr. However, the upper end estimates for these ranges are based on the 1997 Nevada precipitation map, which overestimated the amount of precipitation actually measured at the 11 gages used for this study (table 3 ).

Estimates of long-term (1971-2000) precipitation (table 5) range from $150,000 \mathrm{acre}-\mathrm{ft} / \mathrm{yr}$ (VanDenburgh and others, 1973; Berger and others, 1997), to 200,000 acre-ft/yr (1997 Nevada precipitation map). These long-term estimates are adjusted to the 5-yr period 1998-2002 reported for National Weather Service stations at Reno (92 percent of the 30yr mean) and Virginia City ( 82 percent) for water budget analysis, which yields estimates that ranged from 131,500 to 174,000 acre-ft/yr (table 20). Truckee River streamflow entering the area was 614,000 acre-ft/yr, which was 17,000 acre$\mathrm{ft} / \mathrm{yr}$ greater than the long-term average (table 7) due to above average precipitation that filled reservoirs to near capacity in 1995, 1996, and 1998 (fig. 3). Subsurface inflow from the Fernley Area HA and Truckee Meadows HA were estimated at 3,000 and $200 \mathrm{acre}-\mathrm{ft} / \mathrm{yr}$, respectively, most of which was from water diverted for irrigation. About 616,000 acre-ft/yr leaves the area as streamflow in the Truckee River and the Truckee Canal (table 20). An additional 9,100 acre-ft/yr was diverted for agricultural and industrial uses. ET consumes an estimated $127,000 \mathrm{acre}-\mathrm{ft} / \mathrm{yr}$, with $124,000 \mathrm{acre}-\mathrm{ft} / \mathrm{yr}$ from surface and soil moisture and about 6,000 acre-ft/yr directly from shallow (less than $50 \mathrm{ft}$ ) ground water.

Estimated total ground-water inflow to the Tracy Segment was 78,000-101,000 acre-ft/yr (table 20). About 67 percent of ground-water inflow is from streamflow loss from the Truckee River (71,000 acre-ft/yr). Estimates of recharge from precipitation adjusted to $1998-2002$ data ranged from 2,000 to $22,000 \mathrm{acre}-\mathrm{ft} / \mathrm{yr}$ and recharge of water diverted for agriculture ranged from 10,000 to 13,000 acre-ft/yr. Secondary recharge was about $450 \mathrm{acre}-\mathrm{ft} / \mathrm{yr}$ with $400 \mathrm{acre}-\mathrm{ft} / \mathrm{yr}$ from cooling water for the Tracy Power Station and 50 acre-ft/yr from domestic waste-water disposal and lawn watering. Infiltration of intermittent streamflow was about 1,000 acre-ft/yr, but empirical estimates of recharge from precipitation (VanDenburgh and others, 1973; Nichols, 2000) used for this analysis inherently included recharge from intermittent streamflow.

Ground-water outflow from the Tracy Segment averaged 88,000 acre-ft/yr with about 83 percent estimated from gains in Truckee River streamflow (62,000 acre-ft/yr; table 20). However, Truckee Canal was estimated to lose an average of 9,300 acre-ft/yr along its reach within the Tracy Segment (Mihevc and others, 2002), and much of this loss probably contributed to the gain in Truckee River streamflow. Groundwater pumpage was estimated to be $8,200 \mathrm{acre}-\mathrm{ft} / \mathrm{yr}$ (table 20) and subsurface outflow to Dodge Flat HA averaged 2,400 acre-ft/yr.

Total mean annual inflow and outflow for the area were estimated to equal 490,000 acre-ft/yr by VanDenburgh and others (1973) using hydrologic data for 1919-69, which is less than 70 percent of estimates made for this study. Most of the difference is because totals of precipitation (inflow) and ET (outflow) are included in the water budget presented herein, but only portions of precipitation and ET estimated as recharge to and discharge from ground water are included in the earlier water budget (VanDenburgh and others, 1973). Ground-water components estimated for the Tracy Segment in this study are an order of magnitude greater than the estimates made by VanDenburgh and others (1973), primarily because gains and losses of the Truckee River and recharge from irrigation water were considered in this study. Exchange of water between surface water and ground water estimated for this study represents 59-75 percent of total inflow to ground water and 82-84 percent of total outflow (table 20). Infiltration of water diverted for irrigation represented about 13 percent of estimated inflow to ground water. Estimated loss of irrigation water from the Truckee Canal (9,300 acre-ft/yr) represents at least 70 percent of ground-water inflow from diverted water. Neither of these components were included in water-budget estimates by VanDenburgh and others (1973, p. 56).

Estimates of ground-water recharge from precipitation have the largest range (2,000-22,000 acre-ft/yr; table 20), which introduces the most uncertainty to the ground-water budget. The smallest three estimates were made using precipitation distributions used by VanDenburgh and others (1973) and the regression analysis developed by Berger and others (1997) for Spanish Springs Valley HA. Maximum and minimum estimates were determined by subtracting measured ET and estimated intermittent runoff from precipitation distributions estimated by Berger and others (1997; 2,000 acre-ft/yr) and the 1997 Nevada precipitation map (22,000 acre-ft/yr), respectively. The median value of these estimates is about $8,000 \mathrm{acre}-\mathrm{ft} / \mathrm{yr}$. The largest three estimates were made using the precipitation distribution from the 1997 Nevada precipitation map, which overestimated long-term precipitation reported for nearby National Weather Service gages (table 3 ). No estimated precipitation distribution matched all of the gaged locations, but the 1997 Nevada precipitation map overestimated most frequently and may not be appropriate for use at the hydrologic area scale.

Ranges of estimated total outflow from the Tracy Segment and from ground water are smaller than ranges of respective inflows (table 20). Differences in the amount of estimated precipitation are responsible for most of the uncertainties affecting estimates of both inflow (total precipitation and ground-water recharge) and outflow (ET). However, ranges of inflow bracket ranges of outflow, which is based on more physical measurements. 
Table 20. Estimates of water budget and of ground-water inflow and outflow for Tracy Segment Hydrographic Area, west-central Nevada, 1998-2002

[All estimates are in acre-feet per year (acre-ft/yr); - , source does not contribute to budget component]

\begin{tabular}{|c|c|c|}
\hline Source & Hydrographic Area & Ground water \\
\hline \multicolumn{3}{|c|}{ INFLOW } \\
\hline Precipitation $^{1}$ & $130,500-174,000$ & $2,000-22,000$ \\
\hline Truckee River $^{2}$ & 614,000 & 62,000 \\
\hline Infiltration of intermittent streamflow ${ }^{3}$ & - & $500-3,000$ \\
\hline Truckee River diversions ${ }^{2}$ & - & $10,500-13,300$ \\
\hline Subsurface inflow ${ }^{4}$ & 3,200 & 3,200 \\
\hline Secondary recharge from cooling ponds ${ }^{5}$ & - & 400 \\
\hline Secondary recharge from domestic water use ${ }^{6}$ & - & 50 \\
\hline Total inflow (rounded) & 748,000-791,000 & $78,000-103,000$ \\
\hline \multicolumn{3}{|c|}{ OUTFLOW } \\
\hline Evapotranspiration $^{7}$ & $123,500-157,500$ & 4,200 \\
\hline Truckee River $^{2}$ & 508,000 & 71,000 \\
\hline Truckee Canal $^{2}$ & 108,000 & - \\
\hline Other Truckee River diversions ${ }^{2}$ & 9,100 & - \\
\hline Ground-water pumpage $^{8}$ & 8,200 & 8,200 \\
\hline Subsurface outflow ${ }^{4}$ & 2,400 & 2,400 \\
\hline Total outflow (rounded) & $759,000-793,000$ & 86,000 \\
\hline
\end{tabular}

\footnotetext{
${ }^{1}$ Three values obtained from three different estimates of precipitation distribution (table 4). Long-term (1971-2000) mean-annual precipitation adjusted to 1998-2002 annual means recorded at National Weather Service stations at Reno and Virginia City, Nevada.

${ }^{2}$ Rounded values from sites 13, 16, and 17 (table 7).

${ }^{3}$ Ground-water recharge from intermittent streamflow is included in recharge from precipitation estimated by coefficients used by VanDenburgh and others, 1973; and Nichols, 2000. See Table 16.

${ }^{4}$ Subsurface inflow from Fernley Area Hydrographic Area and outflow to Dodge Flat Hydrographic Area. Estimated using Darcy's Law and available water levels near hydrographic area boundary, and aquifer width and transmissivity.

${ }^{5}$ Estimate reported by Sierra Pacific Power Company and Ebasco Environmental, 1993, p. 4-4.

${ }^{6}$ Estimated to be 0.15 acre-ft/yr/residence.

${ }^{7}$ Estimated to be $11.5 \mathrm{in} / \mathrm{yr}$ for area above $6,000 \mathrm{ft}$ and $11.7 \mathrm{in} / \mathrm{yr}$ for area less than or equal to $6,000 \mathrm{ft}$ altitude.

${ }^{8}$ Total pumpage (table 19).
}

\section{Summary and Conclusions}

The Tracy Segment is a $285 \mathrm{mi}^{2}$ sub-area of the Truckee River Basin located between USGS Truckee River streamflow-gaging stations at Vista (10350000) and at Wadsworth (10351650) in west-central Nevada. Ongoing development in the area has caused concern about whether its water resources are sufficient for both existing and proposed uses. Water resources in the Tracy Segment were last evaluated as part of a brief appraisal of the entire Truckee River Basin which estimated the perennial yield of basin-fill aquifers in the Tracy Segment at 6,000 acre-ft/yr. Ground-water use has since increased to more than 8,000 acre-ft/yr and many applications are pending. The USGS began a cooperative program with Storey County in 2000 to re-evaluate hydrologic components of the water budget for the Tracy Segment.

Bedrock and basin-fill sediments are the major hydrogeologic units within the Tracy Segment. Most bedrock consists of volcanic rock (primarily andesite, basalt, and rhyolite) that has accumulated as sequences of flows, flow breccias, tuffs, tuff-breccias, and conglomerates. Basin-fill sediments occur mostly beneath the relatively narrow Truckee River canyon. Less-extensive deposits are found locally along ephemeral tributaries of the river, but most of these deposits are above the water table. More than 500 wells have been constructed within the Tracy Segment, mostly in basin fill but increasingly in bedrock.

The distribution and volume of mean-annual precipitation in the Tracy Segment have been estimated using (1) a previously published precipitation distribution relating precipitation measurements to altitude and dominant vegetation, (2) a precipitation map for Nevada produced in 1997, and (3) a previously published relation between precipitation stations in northwestern Nevada and altitude. The first and third estimates totaled 150,000 acre- $\mathrm{ft} / \mathrm{yr}$ and the second estimate totaled 200,000 acre-ft/yr.

Non-phreatophytic ET was estimated using data measured at two micrometeorological stations at altitudes of about 5,000 and $6,000 \mathrm{ft}$ by using the Bowen-ratio method. The lower altitude site was established in a desert-shrub plant com- 
munity typical of 66 percent of the area and the higher altitude site was in a pinion-juniper forest typical of 17 percent of the area. Total ET during water year 2002 was $11.5 \mathrm{in} / \mathrm{yr}$ at the pinion-juniper site and $11.7 \mathrm{in} / \mathrm{yr}$ at the desert-shrub site.

The Truckee River is the only perennial stream in the area, except for isolated reaches of tributary channels that received discharge from springs. Average flow of the Truckee River for the period of record common to streamflow-gaging stations within the Tracy Segment (1998-2002) was 614,000 acre-ft/yr near the upstream hydrographic-area boundary and the sum of average flows at two stations near the downstream boundary crossed by the Truckee River and Truckee Canal total 616,000 acre-ft/yr. Water diverted from the Truckee River to the Newlands Reclamation Project in the Carson River Basin via the Truckee Canal averaged 108,000 acre-ft/yr for the same period. Five active agricultural diversions and three industrial diversions total an average of 9,000 acre-ft/yr. There also are about $390 \mathrm{mi}$ of ephemeral stream channels, with almost 70 percent of the channels within 4 subbasins of the HA. The volume of runoff from these ungaged streams was estimated using an empirical relation to be 5,000 acre-ft/yr.

Gaging-station data indicated that Truckee River gains $15,000 \mathrm{acre}-\mathrm{ft} / \mathrm{yr}$ of streamflow from ground-water discharge and irrigation-return flows between the upstream boundary and the streamflow-gaging station near Tracy. About 61,000 acre-ft/yr of streamflow was lost to ground water between the gaging station near Tracy and the diversion at Derby Dam, and 58,000 acre-ft/yr was gained from ground water and irrigation-return flows between the dam and the downstream hydrographic-area boundary near Wadsworth. Seepage loss to ground water beneath the Truckee Canal was estimated to be 9,000 acre-ft/yr; much of which contributes, along with operational return flows from the canal, to streamflow in this lower reach of the Truckee River.

Water levels in 30 wells ranged from about $25 \mathrm{ft}$ above land surface at a flowing well completed in permeable bedrock near an altitude of $6,000 \mathrm{ft}$ to more than $400 \mathrm{ft}$ below land surface in a test well completed in bedrock beneath an alluvial fan near an altitude of 4,700 ft. Water levels measured in wells completed in basin-fill deposits near the Truckee River were less than $30 \mathrm{ft}$ below land surface and indicate a horizontal hydraulic-gradient of 0.002 , which was nearly parallel to the gradient of the river. Estimated vertical hydraulic-gradients between 17 water wells near the river and the stage of the Truckee River generally support the distribution of gains and losses of the river. In the upstream reach of the Truckee River, a measured upward gradient between the bedrock aquifer and river appears responsible for the measured gain in streamflow. Within the river reach between the streamflow-gaging stations near Tracy and below Derby Dam, the water table was at a lower altitude than the river's stage, and streamflow that is lost in this reach has the potential to seep to the water table. Near the gaging station at Wadsworth, water-table altitudes were higher than stream stage, indicating potential for ground water to contribute to streamflow.

Ground-water samples were collected from 11 wells for determination of dissolved concentrations of major ions, selected trace elements and ratios of oxygen and hydrogen stable isotopes of water. Composition of delta deuterium and delta oxygen-18 in samples from the Truckee River ranged from -79.8 to -77.2 permil and from -9.38 to -9.26 permil, respectively. In 11 ground-water samples, compositions of the two stable isotopes ranged from -125.1 to -81.2 permil and from -15.81 to -9.8 permil, respectively. On the basis of isotopic composition of Truckee River water and 3 groundwater samples collected from wells in the mountain blocks, 8 ground-water samples are mixtures of about 11 to 94 percent river water. Results of laboratory analyses of regulated inorganic constituents indicate ground water generally is suitable for drinking and industrial use with a few exceptions. The current MCL for dissolved arsenic $(50 \mu \mathrm{g} / \mathrm{L})$ is the only one of 12 adopted by the State of Nevada that was exceeded in 3 sampled wells, and the soon-to-be adopted MCL $(10 \mu \mathrm{g} / \mathrm{L})$ was equaled or exceeded at 4 additional sites. The MCL the U.S. Environmental Protection Agency has proposed for dissolved radon gas $(300 \mathrm{pCi} / \mathrm{L})$ was exceeded in all groundwater samples. The State of Nevada has promulgated SMCLs that are recommended for aesthetic reasons. Concentrations of dissolved fluoride ( $2 \mathrm{mg} / \mathrm{L})$ at three wells, $\mathrm{pH}$ (6.5 to 8.5 standard units) at one well, and dissolved solids $(1,000 \mathrm{mg} / \mathrm{L})$ at one well exceeded Nevada SMCLs.

A water budget for the Tracy Segment was estimated for water years 1998 through 2002 using measurements and other data compiled during this study. Estimates of total inflow and outflow ranged from 748,000 to 791,000 acre-ft/yr and 759,000 to 793,000 acre-ft/yr, respectively. Estimates of inflow to ground water ranged from 78,000 to 101,000 acre- $\mathrm{ft} / \mathrm{yr}$ and outflow from ground water is 88,000 acre-ft/yr. Ground-water inflow estimated in this study totaled about one order of magnitude greater than an earlier estimate, primarily because the budget developed for this study accounted for gains and losses of the Truckee River and recharge from irrigation diversions.

Surface water of the Truckee River dominates both total and ground-water budget estimates, comprising about 80 percent of total inflow $(614,000$ acre-ft/yr) and outflow $(616,000$ acre-ft/yr) and about 67 and 83 percent of ground-water inflow $(62,000 \mathrm{acre}-\mathrm{ft} / \mathrm{yr})$ and outflow $(71,000 \mathrm{acre}-\mathrm{ft} / \mathrm{yr})$, respectively. About 14 percent of the total outflow from the Tracy Segment is exported in the Truckee Canal for agricultural use at the Newlands Reclamation Project and 12 percent of estimated ground-water inflow is recharged by losses from irrigation diversions $(10,000-13,000 \mathrm{acre}-\mathrm{ft} / \mathrm{yr})$ with most $(9,300$ acre-ft/yr) from the Truckee Canal which contributes, along with operational spill and return flows, to measured gains in Truckee River streamflow. 
Estimates of precipitation ranged from 16 to 23 percent $(130,500-174,000$ acre-ft/yr) of the total inflow and 2 to 28 percent $(2,000-22,000$ acre-ft/yr) of inflow to ground water. Subsurface inflow from the Fernley Area and Truckee Meadows HAs is less than 1 percent (3,200 acre-ft/yr) of total inflow and about 4 percent of inflow to ground water. Secondary recharge from the cooling pond at the Tracy Power Station and from domestic waste-water disposal and lawn watering contributed less than 1 percent ( $450 \mathrm{acre}-\mathrm{ft} / \mathrm{yr}$ ) to ground-water inflow. ET accounts for about 16-19 percent $(123,500-157,500 \mathrm{acre}-\mathrm{ft} / \mathrm{yr})$ of the total outflow from the area of which phreatophytes transpire 7 percent $(6,000$ acre-ft/yr) of estimated ground-water outflow. Ground-water pumpage reported as permitted or certificated is about 1 percent $(8,200$ acre-ft/yr) of total outflow and 10 percent of ground-water outflow. Subsurface outflow to Dodge Flat HA is less than 1 percent $(2,400$ acre-ft/yr) of total outflow and 4 percent of ground-water outflow. Differences in estimated precipitation are responsible for most of the uncertainties affecting estimates of both inflow (total precipitation and ground-water recharge) and outflow (ET).

\section{References Cited}

Allison, G.B., and Hughes, M.W., 1978, The use of environmental chloride and tritium to estimate total recharge to an unconfined aquifer: Australian Journal of Soil Research, v. 16, p. 181-195.

Allison, G.B., Gee, G.W., and Tyler, S.W., 1994, A review of vadose-zone techniques for estimating groundwater recharge in arid and semiarid regions: Soil Science Society of America Journal, v. 58, p. 63-72.

Archer, W.M., 1990, Soil survey of Storey County area, Nevada: U.S. Department of Agriculture, Natural Resources Conservation Service, 289 p.

Bauer, D.J., Foster, B.J., Joyner, J.D., and Swanson, R.A., 1996, Water resources data, Nevada, water year 1995: U.S. Geological Survey Water-Data Report NV-95-1, 734 p.

Baumer, O.W., 1983, Soil survey of Washoe County, Nevada, south part: U.S. Department of Agriculture, Natural Resources Conservation Service, 608 p.

Bell, J.W., 1981, Quaternary fault map of the Reno quadrangle [Nevada]: U.S. Geological Survey Open-File Report 81-982, 62 p.

Berger, D.L., Johnson, M.J., and Tumbusch, M.L., 2001, Estimates of evapotranspiration from the Ruby Lake National Wildlife Refuge area, Ruby Lake Valley, northeast Nevada, May 1999-October 2000: U.S. Geological Survey WaterResources Investigations Report 01-4234, 38 p.
Berger, D.L., Ross, W.C., Thodal, C.E., and Robledo, A.R., 1997, Hydrogeology and simulated effects of urban development on water resources of Spanish Springs Valley, Washoe County, west-central Nevada: U.S. Geological Survey Water-Resources Investigations Report 96-4297, 80 p.

Berris, S.N., 1996, Daily flow-routing simulations for the Truckee River, California and Nevada: U.S. Geological Survey Water-Resources Investigations Report 96-4097, 83 p.

Berris, S.N., Crompton, E.J., Joyner, J.D., and Ryan, Roslyn, 2003, Water resources data, Nevada, water year 2002: U.S. Geological Survey Water-Data Report NV-02-1, 600 p.

Bonham, H.F., and Papke, K.G., 1969, Geology and mineral deposits of Washoe and Storey Counties, Nevada: Nevada Bureau of Mines and Geology, Bulletin 70, 140 p.

Bonnin, G.M., Todd, Deborah, Lin, Bingzhang, Parzybok, Tye, Yekta, Michael, and Riley, David, 2004, Precipitation-frequency atlas of the United States: National Oceanic and Atmospheric Administration Atlas 14, v. 1, version 3, accessed July 6, 2004, at URL http://www.nws.noaa. gov/ohd/hdsc/.

Bortolin, Greg, 2003, Governor Guinn announces \$8 million from EPA for Nevada drinking water loan fund: Office of Governor Kenny Guinn, accessed December 22, 2003, at URL http://gov.state.nv.us/pr/2003/10-01WATER.htm

Brown, W.M., III, Nowlin, J.O., Smith, L.H., and Flint, M.R., 1986, River-quality assessment of the Truckee and Carson River System, California and Nevada-Hydrologic characteristics: U.S. Geological Survey Open-File Report 84-576, $201 \mathrm{p}$.

Caicco, S.L., 1998, Current status, structure, and plant species composition of the riparian vegetation of the Truckee River, California and Nevada: Madroño, v. 45, no. 1, p. 17-30.

Cardinalli, J.L., Roach, L.M., Rush, F.E., and Vasey, B.J., 1968, State of Nevada hydrographic areas: Nevada Division of Water Resources map, scale 1:500,000.

Claassen, H.C., Reddy, M.M., and Halm, D.R., 1986, Use of the chloride ion in determining hydrologic-basin water budgets-A 3-year case study of the San Juan Mountains, Colorado, U.S.A.: Journal of Hydrology, v. 85, p. 49-71.

Clary, S.L., McClary, D.R., Whitney, Rita, and Reeves, D.D., 1995, Water resources data, Nevada, water year 1994: U.S. Geological Survey Water-Data Report NV-94-1, 768 p.

Consulting Services Associates, Inc., 1997, Asamera Minerals (U.S.) Inc. water rights report: Technical Report, 10 p. with appendices.

Coplen, T.B., 1994, Reporting of stable hydrogen, carbon, and oxygen isotopic abundances: Pure and Applied Chemistry, v. 66, p. 273-276. 
Coplen, T.B., 2000, A guide for the Laboratory Information Management System (LIMS) for light stable isotopes: U.S. Geological Survey Open-File Report 00-345, 121 p.

Cothern, C.R., 1987, Development of regulations for radionuclides in drinking water, in Graves, Barbara, ed., Radon, radium, and other radioactivity in ground water: Chelsea, Mich., Lewis Publishers, p. 1-11.

Craig, Harmon, 1961, Isotopic variations in meteoric waters: Science, v. 133 , no. 3465 , p. 1702-1703.

Dalrymple, Tate, and Benson, M.A., 1967, Measurement of peak discharge by the slope-area method: U.S. Geological Survey Techniques of Water-Resources Investigations, Book 3, Applications of Hydraulics, chap. A2, 12 p.

Daly, Christopher, Neilson, R.P., and Phillips, D.L., 1994, A statistical topographic model for mapping climatological precipitation over mountainous terrain: Journal of Applied Meteorology, v. 33, p. 140-158.

Dettinger, M.D., 1989, Reconnaissance estimate of natural recharge to desert basins in Nevada, U.S.A., by using chloride-balance calculations: Journal of Hydrology, v. 106, p. 55-78.

Gardner, W.H., 1965, Water content, chapter 7, in Black, C.A., ed., Methods of soil analysis, Part 1, physical and mineralogical properties, including statistics of measurement and sampling: Madison, Wisc. American Society of Agronomy, Inc., p. 82-127.

Gee, G.W., and Hillel, Daniel, 1988, Groundwater recharge in arid regions-review and critique of estimation methods: Hydrological Processes, v. 2, p. 255-266.

Halford, K.J., and Kuniansky, E.L., 2002, Documentation of spreadsheets for the analysis of aquifer-test and slug-test data: U.S. Geological Survey Open-File Report 02-197, available online at http://pubs.water.usgs.gov/ofr02197.

Hardman, George, 1936, Nevada precipitation and acreages of land by rainfall zones: Reno, University of Nevada Agricultural Experiment Station mimeographed report, 10 p. and map.

Hardman, George, 1965, Nevada precipitation map, adapted from map prepared by George Hardman, Victor Kral, and others, 1936: University of Nevada, Reno, Agricultural Experiment Station Bulletin 185, 27 p.

Hardman, George, and Mason, H.G., 1949, Irrigated lands of Nevada: University of Nevada, Reno, Agricultural Experiment Station Bulletin 183, 57 p.
Harrill, J.R., and Moore, D.O., 1970, Effects of groundwater development on the water regime of Paradise Valley, Humboldt County, Nevada, 1948-68 and hydrologic reconnaissance of the tributary areas: Nevada Division of Water Resources Bulletin 39, 123 p.

Harrill, J.R., Gates, J.S., and Thomas, J.M., 1988, Major ground-water flow systems in the Great Basin region of Nevada, Utah, and adjacent states: U.S. Geological Survey Hydrologic Investigations Atlas HA-694-C.

Harrill, J.R., and Preissler, A.M., 1994, Ground-water flow and simulated effects of development in Stagecoach Valley, a small, partly drained basin in Lyon and Storey Counties, western Nevada: U.S. Geological Survey Professional Paper 1409-H, 74 p.

Healy, R.W., and Ronan, A.D., 1996, Documentation of computer program VS2DH for simulation of energy transport in variably saturated porous media-modification of the U.S. Geological Survey's computer program VS2DT: U.S. Geological Survey Water-Resources Investigations Report 96-4230, 36 p.

Heath, R.C., 1983, Basic ground-water hydrology: U.S. Geological Survey Water-Supply Paper 2220, 84 p.

Hess, D.L., Mello, K.A., Sexton, R.J., and Young, R.L., 1993, Water resources data, Nevada, water year 1992: U.S. Geological Survey Water-Data Report NV-92-1, 511 p.

Horton, G.A., 1997, Truckee River chronology, a chronological history of the Truckee River and related water issues: Nevada Division of Water Planning, four numbered sections.

Izbicki, J.A., 2002, Geologic and hydrologic controls on the movement of water through a thick, heterogeneous unsaturated zone underlying an intermittent stream in the western Mojave Desert, southern California: Water Resources Research, v. 38, no. 3, p. 2-1-14.

Izbicki, J.A., Michel, R.L., and Martin, Peter, 1998, Chloride and tritium concentrations in a thick unsaturated zone underlying an intermittent stream in the Mohave Desert, southern California, USA in Brahama, J., and others, eds., Gambling with groundwater-physical, chemical, and biological aspects of aquifer-stream relations: American Institute of Hydrology, St. Paul, p. 43-56.

Jacob, C.E. and Lohman, S.W., 1952, Nonsteady flow to a well of constant drawdown in an extensive aquifer: Transaction of the American Geophysical Union, v. 33, no. 4, p. 559-569.

James, J.W., 1986, Climatological data, Nevada, special weather summary, February, 1986: National Oceanic and Atmospheric Administration, Climatic Data Center, v. 101, no. 2, unpaginated. 
James, J.W., 1995, Nevada climate summary, August 1995: Office of the State Climatologist, v. 12, no. 8, 4 p.

Jennings, Michael, and Scott, J.M., 1997, Official description of the National Gap Analysis Program, Biological Resources Division: U.S. Geological Survey, accessed July 21, 2003, online at http://www.gap.uidaho.edu/About/Overview/GapDescription/default.htm

Jones, Jeanine, Maxwell, S.R., and Hayward, Patricia, 1991, Truckee River atlas: California Department of Water Resources, 128 p.

Laczniak, R.J., DeMeo, G.A., Reiner, S.R., Smith, J.L., and Nylund, W.E., 1999, Estimates of ground-water discharge as determined from measurement of evapotranspiration, Ash Meadows Area, Nye County, Nevada: U.S. Geological Survey Water-Resources Investigations Report 99-4079, 70 p.

Lapham, W.W., 1989, Use of temperature profiles beneath streams to determine rates of vertical ground-water flow and vertical hydraulic conductivity: U.S. Geological Survey Water-Supply Paper 2337, 35 p.

Lico, M.S., 1992, Data for radon-222 and other radionuclides in ground water, Nevada, 1986-1989: U.S. Geological Survey Open-File Report 91-488, 17 p.

Lowry, J.D., Hoxie, D.C., and Moreau, Eugene, 1987, Extreme levels of $\mathrm{Rn}$ and $\mathrm{U}$ in a private water supply, in Graves, Barbara, ed., Radon, radium, and other radioactivity in ground water: Chelsea, Mich., Lewis Publishers, p. 363-375.

Maurer, D.K., 1997, Hydrology and ground-water budgets of the Dayton Valley Hydrographic Area, west-central Nevada: U.S. Geological Survey Water-Resources Investigations Report 97-4123, 89 p.

Maurer, D.K., and Thodal, C.E., 2000, Quantity and chemical quality of recharge, and updated water budgets, for the basin-fill aquifer in Eagle Valley, western Nevada: U.S. Geological Survey Water-Resources Investigations Report 99-4289, 46 p.

Maxey, G.B., and Eakin, T.E., 1949, Ground water in White River Valley, White Pine, Nye, and Lincoln Counties, Nevada: Nevada State Engineer, Water Resources Bulletin $8,59 \mathrm{p}$.

McCord, J.T., Gotway, C.A., and Conrad, S.H., 1997, Impact of geologic heterogeneity on recharge estimation using environmental tracers-Numerical modeling investigation: Water Resources Research, v. 33, no. 6, p. 1229-1240.

Mihevc, Todd, Pohll, Greg, Niswonger, Rich, and Stevick, Elizabeth, 2002, Truckee Canal seepage analysis in the Fernley/Wadsworth area: Desert Research Institute, Publication No. 41176, 44 p.
Moore, J.G., 1969, Geology and mineral deposits of Lyon, Douglas, and Ormsby Counties, Nevada: Nevada Bureau of Mines and Geology Bulletin 75, 42 p.

Moore, D.O., 1976, Estimating peak discharges from small drainages in Nevada according to basin areas within elevation zones: Nevada Highway Department Hydrologic Report No. 3, 17 p.

National Climate Data Center, accessed July 1, 2003 at http:/ www.wrcc.dri.edu/.

Nevada Division of Water Planning, 1992, Nevada water facts: Carson City, Nevada, 79 p.

Nichols, W.D., 1992, Energy budgets and resistances to energy transport in sparsely vegetated rangeland: Agricultural and Forest Meteorology, v. 60, p. 221-247.

Nichols, W.D., 1994, Groundwater discharge by phreatophyte shrubs in the Great Basin as related to depth to groundwater: Water Resources Research, v. 30, no. 12, p. 3265-3274.

Nichols, W.D., 2000, Regional ground-water evapotranspiration and ground-water budgets, Great Basin, Nevada: U.S. Geological Survey Professional Paper 1628, 82 p.

Phillips, F.M., 1994, Environmental tracers for water movement in desert soils of the American Southwest: Soil Society of America Journal, v. 58, p. 15-24.

Pohll, Greg, McGraw, David, Ralston, Jill, Bohm, Burkhard, Thomas, Jim, McKay, Alan, Widmer, Mike, Minor, Tim, Lamorey, Gregg, Dahan, Ofer, Carroll, Rosemary, Cupp, Kurt, Jacobson, Elizabeth, McDonald, Eric, Stevick, Elizabeth, and Huntington, Justin, 2001, Evaluation of groundwater and solute transport in the Fernley-Wadsworth area: Desert Research Institute, Publication No. 41173, 246 p. accessed October 6, 2003, online at http://www.truckee.dri. edu/fernley/FernleyFinalReport.pdf.

Pritt, J.W., and Raese, J.W., 1995, Quality assurance/quality control manual-National Water Quality Laboratory: U.S. Geological Survey Open-File Report 95-443, 35 p.

PTI Environmental Services, 1997, Effects of pumping the proposed Olinghouse Mine supply well on Dodge Flat and the Truckee River, Washoe County, Nevad: Technical Report, 4 numbered sections.

Pupacko, A., LaCamera, R.J., Riek, M.M., and Wood, D.B., 1988, Water resources data, Nevada, water year 1986: U.S. Geological Survey Water-Data Report NV-86-1, 263 p.

Radtke, D.B., Wilde, F.D., Davis, J.V., and Popowski, T.J., 1998, Alkalinity and acid neutralizing capacity, chapter A6.6, in National field manual for the collection of waterquality data: U.S. Geological Survey Techniques of WaterResources Investigations, Book 9, Handbooks for WaterResources Investigations [variously paged]. 
Reheis, Marith, 1999, Extent of Pleistocene lakes in the western Great Basin: U.S. Geological Survey Miscellaneous Field Studies Map MF-2323.

Rose, R.L., 1969, Geology of parts of the Wadsworth and Churchill Butte Quadrangles, Nevada: Nevada Bureau of Mines and Geology, Bulletin 71, 27 p.

Rush, F.E., 1968, Index of hydrographic areas in Nevada: Nevada Division of Water Resources, Information Report 6, $38 \mathrm{p}$.

Scanlon, B.R., 1991, Evaluation of moisture flux from chloride data in desert soils: Journal of Hydrology, v. 128, p. 137-156.

Schaeffer, S.M., Williams, D.G., and Goodrich, D.C., 2000, Transpiration of cottonwood/willow forest estimated from sap flux: Agricultural and Forest Meteorology, v. 105, p. 257-270.

Sierra Pacific Power Company and Ebasco Environmental, 1993, Final Pinion Pine power project water quality report-a supplement to the environmental information volume for the Department of Energy: Sacramento, Calif., [variously paged].

Smith, J.L., Reece, B.D., and Medina, R.L., 2001, Data sets and related information used for estimating regional groundwater evapotranspiration in eastern Nevada: U.S. Geological Survey Open-File Report 99-242, 65 p.

Stewart, J.H., 1980, Geology of Nevada-A discussion to accompany the geologic map of Nevada: Nevada Bureau of Mines and Geology Special Publication 4, 136 p.

Stockton, E.L., Jones, C.Z., Rowland, R.C., and Medina, R.L., 2004, Water resources data, Nevada, water year 2003, U.S. Geological Survey Water-Data Report NV-03-1, 697 p.

U.S. Census Bureau, Census 2000: accessed November 25, 2001, online at http://censtats.census.gov/data/NV/

U.S. Environmental Protection Agency, 1999, Technical Factsheet-proposed radon in drinking water rule: EPA 815-F-99-006, accessed April 4, 2005, available online at http://www.epa.gov/safewater/radon/fact.html
U.S. Geological Survey, 1972, Water resources data for Nevada, 1971: U.S. Geological Survey Water Data Report, $239 \mathrm{p}$.

U.S. Geological Survey, 2002, The national map elevation: U.S. Geological Survey Fact Sheet 106-02, available online at http://erg.usgs.gov/isb/pubs/factsheets/fs10602.html

U.S. Geological Survey, variously dated, National field manual for the collection of water-quality data: U.S. Geological Survey Techniques of Water-Resources Investigations, book 9, chaps. A1-A9, available online at http://pubs.water.usgs. gov/twri9A.

U.S. Soil Conservation Service, 1992, Nevada irrigation guide: U.S. Department of Agriculture, Natural Resources Conservation Service, 11 numbered chapters.

VanDenburgh, A.S., Lamke, R.D., and Hughes, J.L., 1973, A brief water-resources appraisal of the Truckee River basin, western Nevada: Nevada Division of Water Resources, Reconnaissance Series Report 57, 122 p.

VanDenburgh, A.S., and Arteaga, F.E., 1985, Revised water budget for the Fernley Area, west-central Nevada, 1979: U.S. Geological Survey Open-File Report 84-712, 17 p.

Welch, A.H., Lawrence, S.J., Lico, M.S., Thomas, J.M., and Schaefer, D.H., 1997, Ground-water quality assessment of the Carson River Basin, Nevada and California-results of investigation, 1987-91: U.S. Geological Survey Water-Supply Paper 2356-A, 93 p.

Wilde, F.D., Radtke, D.B., Gibs, Jacob, and Iwatsubo, R.T., eds., 1999, National field manual for the collection of water-quality data: U.S. Geological Survey Techniques of Water-Resources Investigations, book 9, Handbooks for Water-Resources Investigations [variously paged].

Zawislanski, P.T., and Faybishenko, Boris, 1999, New casing and backfill design for neutron logging access boreholes: Ground Water, v. 37, no. 1, p. 33-37. 


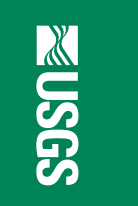

공

ํㅜㄹ

¿

क्ष

$\stackrel{\rho}{I}$

끙

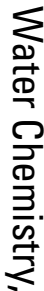

몰

D

这.

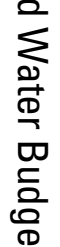

음

공

$\infty$

查

$\stackrel{ }{\risingdotseq}$

Z

ㅇํㅇ

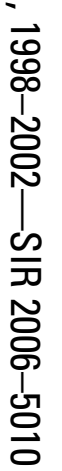

